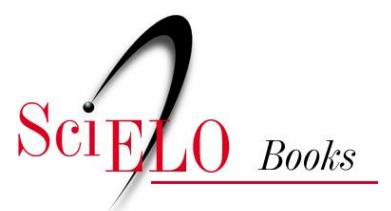

\title{
Quarta expedição
}

\author{
Euclides da Cunha
}

CUNHA, E. Quarta expedição. In: Os sertões [online]. Rio de Janeiro: Centro Edelstein de Pesquisas Sociais, 2010. pp. 296-428. ISBN: 978-85-7982-007-6. https://doi.org/10.7476/9788579820076.0007.

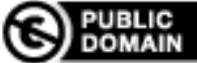

This work is free of known copyright restrictions. http://creativecommons.org/publicdomain/mark/1.0/

Este trabalho está livre de restrições de direito de autor e/ou de direitos conexos conhecidas.

http://creativecommons.org/publicdomain/mark/1.0/

Esta obra está libre de restricciones conocidas de derechos autorales. http://creativecommons.org/publicdomain/mark/1.0/ 


\section{Capítulo I}

I. Desastres. Canudos - uma diátese. A rua do Ouvidor e as caatingas. Versões disparatadas. Mentiras heroicas. O cabo Roque. Levantamento em massa. Planos. Um tropear de bárbaros.

II. Mobilização de tropas. Concentração em Queimadas. Organiza-se a expedição. Delongas. Não há um plano de campanha. A comissão de engenheiros. A marcha. Incidentes. Um guia temeroso: Pajeú. Passagem nas Pitombas. O alto da Favela. Uma divisão aprisionada.

III. Coluna Savaget. Cocorobó. Diante das trincheiras. Carga de baionetas excepcional. A travessia. Macambira e Trabubu. Emissário inesperado. Destrói-se um plano de campanha.

IV. Vitória singular. Começo de uma batalha crônica. Aventuras do cerco. Caçadas perigosas. Desânimos. A atitude do comando-em-chefe.

V. O assalto: preparativos; o recontro. Nova vitória desastrosa. Nos flancos de Canudos. Triunfos pelo telégrafo.

VI. Pelas estradas. Os feridos. Primeiras notícias certas. Versões e lendas.

VII. A brigada Girard. Heroísmo estranho. Em viagem para Canudos.

VIII. Novos reforços. O marechal Carlos Machado Bittencourt. Colaboradores prosaicos demais.

\section{Desastres}

A nova deste revés foi um desastre maior.

A quarta expedição organizou-se através de grande comoção nacional, que se traduziu em atos contrapostos à própria gravidade dos fatos. Foi a princípio o espanto; depois um desvairamento geral da opinião; um intenso agitar de conjecturas para explicar o inconceptível do acontecimento e induzir uma razão de ser qualquer para aquele esmagamento de uma força numerosa, bem aparelhada e tendo chefe de tal quilate. Na desorientação completa dos espíritos, alteou-se logo, primeiro esparsa em vagos comentários, condensada depois em inabalável certeza, a ideia de que não agiam isolados os tabaréus turbulentos. Eram a vanguarda de ignotas falanges prontas a irromperem, de remanente, em toda a parte, convergentes sobre o novo regime. E como nas capitais, federal e estaduais, há muito, meia dúzia de platônicos, revolucionários contemplativos e mansos, se agitavam esterilmente na propaganda da restauração monárquica, fez-se de tal circunstância ponto de partida para a mais contraproducente das reações.

\section{Canudos - uma diátese}

Era preciso uma explicação qualquer para sucessos de tanta monta. Encontraram-na: os distúrbios sertanejos significavam pródromos de vastíssima conspiração contra as instituições recentes. Canudos era uma Coblentz de pardieiros. Por detrás da envergadura desengonçada de Pajeú se desenhava o perfil fidalgo de um Brunswick qualquer. A dinastia em disponibilidade, de Bragança, encontrara afinal um Monck, João Abade. E Antônio Conselheiro - um Messias de feira - empolgara nas mãos trementes e frágeis os destinos de um povo...

A República estava em perigo; era preciso salvar a República. Era este o grito dominante sobre o abalo geral...

Exageramos? 
Deletreemos, ao acaso, qualquer jornal daqueles dias.

Doutrinava-se:

O que de um golpe abalava o prestígio da autoridade constituída e abatia a representação do brio da nossa pátria no seu renome, na sua tradição e na sua força era o movimento armado que, à sombra do fanatismo religioso, marchava acelerado contra as próprias instituições, não sendo lícito a ninguém iludir-se mais sobre o pleito em que audazmente entravam os saudosos do Império, francamente em armas.

Concluía-se:

Não há quem a esta hora não compreenda que o monarquismo revolucionário quer destruir com a República a unidade do Brasil ${ }^{1}$.

\section{Explicava-se:}

A tragédia de 3 de março, em que juntamente com o Moreira César perderam a vida o ilustre coronel Tamarindo e tantos outros oficiais briosíssimos do nosso exército, foi a confirmação de quanto o partido monarquista à sombra da tolerância do poder público, e graças até aos seus involuntários alentos, tem crescido em audácia e força ${ }^{2}$.

Afirmava-se:

Trata-se da Restauração; conspira-se; forma-se o exército imperialista. O mal é grande; que o remédio corra parelhas com o mal. A monarquia arma-se? Que o presidente chame às armas os republicanos ${ }^{3}$.

E assim por diante. A opinião nacional esbatia-se de tal modo na imprensa. Na imprensa e nas ruas.

Alguns cidadãos ativos congregaram o povo na capital da República e resumiram-lhe a ansiedade patriótica numa moção incisiva:

O povo do Rio de Janeiro reunido em meeting e ciente do doloroso revés das armas legais nos sertões da Bahia, tomadas pela caudilhagem monárquica, e congregado em torno do governo, aplaudindo todos os atos de energia cívica que praticar pela

${ }^{1}$ Gazeta de Notícias.

${ }_{3}^{2}$ O País. desafronta do exército e da Pátria, aguarda ansioso, a sufocação da revolta.

A mesma toada em tudo. Em tudo a obsessão do espantalho monárquico, transmudando em legiões - coorte misteriosa marchando surdamente na sombra - meia dúzia de retardatários, idealistas e teimosos.

O presidente da República por sua vez quebrou a serenidade habitual:

Sabemos que, por detrás dos fanáticos de Canudos, trabalha a política. Mas nós estamos preparados, tendo todos os meios para vencer, seja como for contra quem for.

\section{Empastelamento de jornais monárquicos}

Afinal a multidão interveio.

Copiemos:

Já era tarde e a excitação do povo aumentava na proporção de sua massa sempre crescente; assim nesta indignação lembraram-se dos jornais monarquistas, e todos por um, em um ímpeto de desabafo, foram às redações e tipografias dos jornais Gazeta da Tarde, Liberdade e Apóstolo, e, apesar de ter a polícia corrido para evitar qualquer assalto a esses jornais, não chegou a tempo de evitá-lo, pois a multidão aos gritos de viva a República e à memória de Floriano Peixoto invadiu aqueles estabelecimentos e destruiu-os por completo, queimando tudo.

Então começaram a quebrar e inutilizar tudo quanto encontraram, atirando, depois, os objetos, livros, papéis, quadros, móveis, utensílios, tabuletas, divisões etc, para a rua de onde foram logo conduzidos para o largo de S. Francisco de Paula, onde formaram uma grande fogueira, ficando outros em montes de destroços na mesma rua do Ouvidor ${ }^{4}$.

\section{A rua do Ouvidor e as caatingas}

Interrompamos, porém, este respigar em ruínas. Mais uma vez, no decorrer dos sucessos que nos propusemos narrar, forramo-nos à demorada análise de acontecimentos que fogem à escala superior da História. As

\footnotetext{
${ }^{4}$ Jornal do Brasil.
} 
linhas anteriores têm um objetivo único: fixar, de relance, símiles que se emparelham na mesma selvatiqueza. A rua do Ouvidor valia por um desvio das caatingas. A correria do sertão entrava arrebatadamente pela civilização adentro. E a guerra de Canudos era, por bem dizer, sintomática apenas. O mal era maior. Não se confinara num recanto da Bahia. Alastrara-se. Rompia nas capitais do litoral. O homem do sertão, encourado e bruto, tinha parceiros porventura mais perigosos.

\section{Valerá a pena defini-los?}

A força portentosa da hereditariedade, aqui, como em toda a parte e em todos os tempos, arrasta para os meios mais adiantados - enluvados e encobertos de tênue verniz de cultura - trogloditas completos. Se o curso normal da civilização em geral os contém, e os domina, e os manieta, e os inutiliza, e a pouco e pouco os destrói, recalcando-os na penumbra de uma existência inútil, de onde os arranca, às vezes, a curiosidade dos sociólogos extravagantes, ou as pesquisas da psiquiatria, sempre que um abalo profundo lhes afrouxa em torno a coesão das leis eles surgem e invadem escandalosamente a História. São o reverso fatal dos acontecimentos, o claro-escuro indispensável aos fatos de maior vulto.

Mas não têm outra função, nem outro valor; não há analisá-los. Considerando-os o espírito mais robusto permanece inerte a exemplo de uma lente de flintglass, admirável no refratar, ampliadas imagens fulgurantes, mas imprestável se a focalizam na sombra.

\section{Deixemo-los; sigamos.}

Antes, porém, insistamos numa proposição única: atribuir a uma conjuração política qualquer a crise sertaneja, exprimia palmar insciência das condições naturais da nossa raça.

\section{Considerações}

O caso, vimo-lo anteriormente, era mais complexo e mais interessante. Envolvia dados entre os quais nada valiam os sonâmbulos erradios e imersos no sonho da restauração imperial. E esta insciência ocasionou desastres maiores que os das expedições destroçadas. Revelou que pouco nos avantajávamos aos rudes patrícios retardatários. Estes, ao menos, eram lógicos. Insulado no espaço e no tempo, o jagunço, um anacronismo étnico, só podia fazer o que fez - bater, bater terrivelmente a nacionalidade que, depois de o enjeitar cerca de três séculos, procurava levá-lo para os deslumbramentos da nossa idade dentro de um quadrado de baionetas, mostrando-lhe o brilho da civilização através do clarão de descargas.

Reagiu. Era natural. O que surpreende é a surpresa originada por tal fato. Canudos era uma tapera miserável, fora dos nossos mapas, perdida no deserto, aparecendo, indecifrável, como uma página truncada e sem número das nossas tradições. Só sugeria um conceito - e é que, assim como os estratos geológicos não raro se perturbam, invertidos, sotopondo-se uma formação moderna a uma formação antiga, a estratificação moral dos povos por sua vez também se baralha, e se inverte, e ondula riçada de sinclinais abruptas, estalando em faults, por onde rompem velhos estádios há muito percorridos.

Sob tal aspecto era, antes de tudo, um ensinamento e poderia ter despertado uma grande curiosidade. A mesma curiosidade do arqueólogo ao deparar as palafitas de uma aldeia lacustre, junto a uma cidade industrial da Suíça...

Entre nós, de um modo geral, despertou rancores. Não vimos o traço superior do acontecimento. Aquele afloramento originalíssimo do passado, patenteando todas as falhas da nossa evolução, era um belo ensejo para estudarmo-las, corrigirmo-las ou anularmo-las. Não entendemos a lição eloquente.

Na primeira cidade da República, os patriotas satisfizeram-se com o auto-de-fé de alguns jornais adversos, e o governo começou a agir. Agir era isto - agremiar batalhões.

\section{Versões disparatadas}

As primeiras notícias do desastre prolongaram por muitos dias a agitação em todo o país. A parte de combate do major Cunha Matos, deficientíssima, mal indicando as fases capitais da ação, eivada de erros singulares, tinha apenas a eloquência do alvoroço com que fora escrita. Incutia nos que a liam o pensamento de uma hecatombe, ulteriormente agravada de outras informações. E estas, instáveis, acirrando num 
crescendo a comoção e a curiosidade públicas, desencontradamente, lardeadas de afirmativas contraditórias, derivavam pelos espíritos inquietos num desfiar de conjeturas intermináveis.

Não havia acertar no abstruso das opiniões com a mais breve noção sobre as coisas. Ideavam-se sucessos sofregamente aceitos com todos os visos de realidade, até que outros, diversos, os substituíssem, dominando por um dia ou por uma hora as atenções, e extinguindo-se por sua vez diante de outras versões efêmeras. De sorte que num alarma crescente - do boato medrosamente boquejado no recesso dos lares à mentira escandalosa rolando com estardalhaço pelas ruas - se avolumaram apreensões e cuidados. Era uma tortura permanente de dúvidas cruciantes. Nada se sabia de positivo. Nada sabiam mesmo os que haviam compartido o revés. Na inconsistência dos boatos, uma informação única tomava os mais diversos cambiantes.

\section{Mentiras heroicas}

Afirmava-se: o coronel Tamarindo não fora morto; salvara-se valorosamente, com um punhado de companheiros leais, e estava a caminho de Queimadas. Contravinha-se: salvara-se, mas estava gravemente ferido em Maçacará, onde chegara exausto.

Depois uma afirmativa lúgubre: o infeliz oficial fora de fato trucidado. E assim em seguida.

Agitavam-se ideias alarmantes: os sertanejos não eram "um bando de carolas fanáticos” eram um “exército instruído, disciplinado” admiravelmente armados de carabinas Mauser , tendo ademais artilharia, que manejavam com firmeza. Alguns dos nossos, e entre eles o capitão Vilarim, haviam sido despedaçados por estilhas de granadas...

\section{O cabo Roque}

Nessas incertezas, a verdade aparecia, às vezes, sob uma forma heroica. A morte trágica de Salomão da Rocha foi uma satisfação ao amorpróprio nacional. Aditou-se-lhe depois, mais emocionante, a lenda do cabo Roque, abalando comovedoramente a alma popular. Um soldado humilde, transfigurado por um raro lance de coragem marcara a peripécia culminante da peleja. Ordenança de Moreira César, quando se desbaratara a tropa, e o cadáver daquele ficara em abandono à margem do caminho, o lutador leal permanecera a seu lado, guardando a relíquia veneranda abandonada por um exército. De joelhos junto ao corpo do comandante, batera-se até ao último cartucho, tombando, afinal, sacrificando-se por um morto...

E a cena maravilhosa, fortemente colorida pela imaginação popular, fez-se quase uma compensação à enormidade do revés. Abriram-se subscrições patrióticas; planearam-se homenagens cívicas e solenes; e, num coro triunfal de artigos vibrantes e odes ferventes, o soldado obscuro transcendia à História quando — vítima da desgraça de não ter morrido trocando a imortalidade pela vida, apareceu com os últimos retardatários supérstites, em Queimadas.

A este desapontamento aditaram-se outros, à medida que a situação se esclarecia. A pouco e pouco se reduzia por um lado, agravando-se por outro, a catástrofe. Os trezentos e tantos mortos das informações oficiais ressurgiam. Três dias depois do recontro, três dias apenas, já se achava em Queimadas, a duzentos quilômetros de Canudos, grande parte da expedição. Uma semana depois, verificava-se, ali, a existência de 74 oficiais. Duas semanas mais tarde, no dia 19 de março, lá estavam — salvos — 1.081 combatentes.

Vimos quantos entraram em ação. Não subtraiamos. Deixemos aí, registrados, estes algarismos inexoráveis. Eles não diminuíram, com a sua significação singularmente negativa, o fervor das adesões entusiásticas.

\section{Levantamento em massa}

Os governadores de Estado, os Congressos, as corporações municipais, continuaram vibrantes no anelo formidável da vingança. E em todas as mensagens, variantes de um ditado único, monótono pela simulcadência dos mesmos períodos retumbantes, persistiu, como aspiração exclusiva, o esmagamento dos inimigos da República, armados pela caudilhagem monárquica. Como o da capital federal, o povo das demais cidades entendeu também deliberar na altura da situação gravíssima, apoiando todos os atos de energia cívica que praticasse o governo pela desafronta do exército e (esta conjunção valia por cem páginas eloquentes) da Pátria. Decretou-se o luto nacional. Exararam-se votos de pesar nas atas 
das sessões municipais mais remotas. Sufragaram-se os mortos em todas as igrejas. E, dando à tristeza geral a nota supletiva da sanção religiosa, os arcebispados expediram aos sacerdotes dos dois cleros ordem para dizerem nas missas a oração Pro pace. Congregaram-se em toda a linha cidadãos ativos, aquartelando. Ressurgiram batalhões, o Tiradentes, o Benjamim Constant, o Acadêmico e o Frei Caneca, feitos de veteranos já endurados ao fogo da revolta anterior, da Armada; - enquanto agremiando patriotas de todos os matizes formavam-se outros, o Deodoro, o Silva Jardim, o Moreira César... Não bastava.

\section{Planos}

No quartel-general do exército abriram-se inscrições para o preenchimento dos claros de diversos corpos. O presidente da República declarou, em caso extremo, chamar às armas os próprios deputados do Congresso Federal, e, num ímpeto de lirismo patriótico, o vice-presidente escreveu ao Clube Militar propondo-se valentemente cingir o sabre vingador. Fervilhavam planos geniais, ideias raras, incomparáveis. Engenheiros ilustres apresentavam o traçado de um milagre de engenharia — uma estrada de ferro de Vila Nova a Monte Santo, saltando por cima de Itiúba, e feita em trinta dias, e rompendo de chofre, triunfalmente, num coro estrugidor de locomotivas acesas, pelo sertão bravio dentro.

É que estava em jogo, em Canudos, a sorte da República...

Diziam-no informes surpreendedores: aquilo não era um arraial de bandidos truculentos apenas. Lá existiam homens de raro valor - entre os quais se nomeavam conhecidos oficiais do exército e da armada, foragidos desde a revolta de setembro, que o Conselheiro avocara ao seu partido.

\section{Um tropear de bárbaros}

Garantia-se: um dos chefes do reduto era um engenheiro italiano habilíssimo, adestrado talvez nos polígonos bravios da Abissínia. Expunham-se detalhes extraordinários: havia no arraial tanta gente que tendo desertado cerca de setecentos só lhes deram pela falta muitos dias depois. E sucessivas, impiedosas, novas notícias acumulavam-se sobre o fardo extenuador de apreensões, premindo as almas comovidas. Assim, estavam já expugnadas pelos jagunços Monte Santo, Cumbe, Maçacará e, talvez, Jeremoabo. As hordas invasoras, depois de saquearem aquelas vilas, marchavam convergentes para o sul, reorganizando-se no Tucano, de onde, acrescidas de novos contingentes, demandavam o litoral, avançando sobre a capital da Bahia...

As gentes alucinadas ouviam um surdo tropear de bárbaros...

Os batalhões de Moreira César eram as legiões de Varus... Encalçavam-nos, na fuga, catervas formidandas.

Não eram somente os jagunços. Em Juazeiro, no Ceará, um heresiarca sinistro, o padre Cícero, conglobava multidões de novos cismáticos em prol do Conselheiro. Em Pernambuco, um maníaco, José Guedes, surpreendia as autoridades, que o interrogavam, com a altaneria estoica de um profeta. Em Minas, um quadrilheiro desempenado, João Brandão, destroçava escoltas e embrenhava-se no alto sertão do S. Francisco, tangendo cargueiros ajoujados de espingardas.

A aura da loucura soprava também pelas bandas do sul: o Monge do Paraná, por sua vez, aparecia nessa concorrência extravagante para a História e para os hospícios.

E tudo isto, punha-se de manifesto, eram feituras de uma conjuração que desde muito vinha solapando as instituições. A reação monárquica tomava afinal a atitude batalhadora precipitando nas primeiras escaramuças, coroadas do melhor êxito, aquela vanguarda de retardatários e de maníacos.

O governo devia agir prontamente. 


\section{Capítulo II}

\section{Mobilização de tropas}

Descoloraram-se batalhões de todos os Estados: $12^{\circ}, 25^{\circ}, 30^{\circ}, 31^{\circ}$, $32^{\circ}$, do Rio Grande do Sul; o $27^{\circ}$, da Paraíba; o $34^{\circ}$, do Rio Grande do Norte; o $33^{\circ}$ e o $35^{\circ}$, do Piauí; o $5^{\circ}$, do Maranhão; o $4^{\circ}$, do Pará; o $26^{\circ}$, de Sergipe; o $14^{\circ}$ e o $5^{\circ}$, de Pernambuco; o $2^{\circ}$, do Ceará; o $5^{\circ}$ e parte do $9^{\circ}$ de Cavalaria, Regimento da Artilharia da Capital Federal: o $7^{\circ}$, o $9^{\circ}$ e o $16^{\circ}$, da Bahia.

O comandante do $2^{\circ}$ Distrito Militar, general Artur Oscar de Andrade Guimarães, convidado para assumir a direção da luta, aceitou-a, tendo antes, numa proclamação pelo telégrafo, definido o seu pensar sobre as coisas: "Todas as grandes ideias tem os seus mártires; nós estamos votados ao sacrifício de que não fugimos para legar à geração futura uma República honrada, firme e respeitada”.

A mesma nota em tudo: era preciso salvar a República...

\section{Concentração em Queimadas}

As tropas convergiam na Bahia. Chegavam àquela capital em batalhões destacados e seguiam imediatamente para Queimadas. Esta medida, além de corresponder à urgência de uma organização pronta naquela vila — feita base de operações provisórias — impunha-se por outro motivo igualmente sério.

É que, generalizando-se de um conceito falso, havia no ânimo dos novos expedicionários uma suspeita extravagante a respeito das crenças monárquicas da Bahia. Ali saltavam com altaneria provocante de triunfadores em praça conquistada. Aquilo, preestabelecera-se, era um Canudos grande. A velha capital com o seu aspecto antigo, alteada sobre a montanha, em que embateram por tanto tempo as chusmas dos "varredores do mar", batavos e normandos; conservando, a despeito do tempo, as linhas tradicionais da antiga metrópole do oceano; ereta para a defesa, com os seus velhos fortes disjungidos, esparsos pelas eminências, acrópoles desmanteladas, canhoneiras abertas para o mar; com as suas ladeiras a prumo, envesgando pela montanha segundo o mesmo traçado das trincheiras de taipa de Tomé de Sousa; e com as suas ruas estreitas e embaralhadas pelas quais passaria hoje Fernão Cardim ou Gabriel Soares sem notar diferenças sensíveis - aparecia-lhes como uma ampliação da tapera sertaneja. Não os comovia; irritava-os. Eram cossacos em ruas de Varsóvia. Nos lugares públicos a população surpreendida ouvia-lhes comentários acerbos, enunciados num fanfarrear contínuo, sublinhado pelo agudo retinir das esporas e das espadas. E a animadversão gratuita, dia a dia avolumando-se, traduzia-se ao cabo em desacatos e desmandos.

Citemos um caso único: os oficiais de um batalhão, o $30^{\circ}$, levaram a dedicação pela República a um assomo iconoclasta. Em pleno dia tentaram despedaçar, a marretadas, um escudo em que se viam as armas imperiais, erguido no portão da alfândega velha. A soldadesca por seu lado, assim edificada, exercitava-se em correrias e conflitos.

A paixão patriótica roçava, derrancada, pela insânia. A imprensa e a mocidade do Norte, afinal, protestaram e, mais eloquente que as mensagens então feitas, falava em toda a parte o descontentamento popular, prestes a explodir.

Assim, como medida preventiva, os batalhões chegavam, desembarcavam, atulhavam os carros da Estrada de Ferro Central e seguiam logo para Queimadas. De sorte que em pouco tempo ali estavam todos os corpos destinados à marcha por Monte Santo; e o comandante geral das forças, em ordem do dia de 5 de abril, pôde organizar a expedição:

\section{Organiza-se a $4^{a}$ expedição}

Nesta data ficam assim definitivamente organizadas as forças sob meu comando:

Os $7^{\circ}, 14^{\circ}$ e $30^{\circ}$ Batalhões de Infantaria constituem a $1^{\text {a }}$ Brigada sob o comando do coronel Joaquim Manuel de Medeiros; $16^{\circ}, 25^{\circ}$ e $27^{\circ}$ Batalhões da mesma arma, a $2^{\text {a }}$ Brigada ao mando do coronel Inácio Henrique Gouveia; $5^{\circ}$ Regimento da Artilharia de Campanha, $5^{\circ}$ e $9^{\circ}$ Batalhões de Infantaria, a $3^{\text {a }}$ Brigada sob o comando do coronel Olímpio da Silveira; $12^{\circ}, 31^{\circ}$ e $33^{\circ}$ da mesma arma e uma divisão de artilharia, a $4^{\text {a }}$ Brigada sob o comando do coronel Carlos Maria da 
Silva Teles; $34^{\circ}, 35^{\circ}$ e $40^{\circ}$, a $5^{\text {a }}$ Brigada sob o comando do coronel Julião Augusto de Serra Martins; $26^{\circ}, 32^{\circ}$ da Infantaria e uma divisão de artilharia, a $6^{\text {a }}$ Brigada sob o comando do coronel Donaciano de Araújo Pantoja.

A $1^{\mathrm{a}}, 2^{\mathrm{a}}$ e $3^{\mathrm{a}}$ Brigadas formaram uma coluna, sob o comando do general João da Silva Barbosa, ficando responsável pela mesma, até a respectiva apresentação daquele general, o coronel comandante da $1^{\text {a }}$ Brigada; a $4^{\mathrm{a}}, 5^{\mathrm{a}}$ e $6^{\mathrm{a}}$ Brigadas outra coluna, sob o comando do general Cláudio do Amaral Savaget.

\section{Crítica}

Estava constituída a expedição.

A ordem do dia nada dizia quanto ao desdobramento das operações, talvez porque este, desde muito conhecido, pouco se desviara do traçado anterior. Resumia-se naquela divisão de colunas. Ao invés de um cerco à distância, para o que eram suficientes aqueles dezesseis corpos articulandose em pontos estratégicos e a pouco constringindo-se em roda do arraial, planeara-se investir com os fanáticos por dois pontos, seguindo uma das colunas, a primeira, por Monte Santo, enquanto a segunda, depois de reunida em Aracaju, atravessaria Sergipe até Jeremoabo.

Destas vilas convergiriam sobre Canudos.

Linhas já escritas dispensam o insistir na importância de semelhante plano - cópia ampliada de erros anteriores, com uma variante única: em lugar de uma eram duas as massas compactas de soldados que iriam tombar, todos a um tempo, englobadamente, nas armadilhas da guerra sertaneja. E quando, agitando as mais favoráveis hipóteses, isto não acontecesse, era fácil verificar que a plena consecução dos itinerários preestabelecidos problematizava ainda um desenlace satisfatório da campanha. À simples observação de um mapa ressaltava que a convergência predeterminada, embora se realizasse, não determinaria o esmagamento da rebelião, mesmo à custa do alvitre extremo e doloroso da batalha.

As estradas escolhidas, do Rosário e de Jeremoabo, interferindo-se fora do povoado, num ponto de sua amplíssima periferia, eram inaptas para o assédio. Os jagunços batidos numa direção única, no quadrante de sudeste, tinham, caso fossem desbaratadas, francos para o ocidente e para o norte, os caminhos do Cambaio, do Uauá e da Várzea da Ema; todo o vasto sertão do S. Francisco, asilo impenetrável a que se acolheriam a salvo e onde se aprestariam para a réplica. Ora, a consideração desse abandono em massa do arraial raiava pelo mais exagerado otimismo. Os sertanejos resistiriam, como resistiram, e, reagindo aos assaltos feitos apenas por um único flanco, teriam como tiveram, pelos outros, mil portas por onde comunicarem com as cercanias e abastecerem-se à vontade.

Eram circunstâncias fáceis de deduzirem-se. E, previstas, apontavam naturalmente um corretivo único: uma terceira coluna, que, partindo de Juazeiro ou Vila Nova, e vencendo uma distância equiparada às percorridas pelas outras, com elas convergisse, trancando a pouco e pouco aquelas estradas, originando por fim um bloqueio efetivo.

Não se cogitou, porém, desta divisão suplementar indispensável. Não havia tempo para tal. O país inteiro ansiava pela desafronta do exército e da pátria...

Era preciso marchar e vencer. O general Savaget seguiu logo, nos primeiros dias de abril, para Aracaju; e o comandante-em-chefe, em Queimadas, dispôs-se para a investida.

\section{Delongas}

Mas esta só se realizaria dois meses depois, em fins de junho. Os lutadores, soldados e patriotas, chegavam à obscura estação da estrada de ferro do S. Francisco e quedavam impotentes para a partida.

O grande movimento de armas de março fora uma ilusão. Não tínhamos exército, na significação real do termo, em que se inclui, mais valiosa que a existência de alguns milhares de homens e espingardas, uma direção administrativa, técnica e tática, definida por um estado-maior enfeixando todos os serviços, desde o transporte das viaturas aos lineamentos superiores da estratégia, órgão preparador por excelência das operações militares.

Faltava tudo. Não havia um serviço de fornecimento organizado, de sorte que numa base de operações provisória, presa ao litoral por uma estrada de ferro, foi impossível conseguir-se um depósito de víveres. Não 
havia um serviço de transporte suficiente para cerca de cem toneladas de munições de guerra.

Por fim não havia soldados: os carregadores de armas, que por ali desembarcaram, não vinham dos polígonos de tiro, ou campos de manobra. Os batalhões chegavam, alguns desfalcados, menores que companhias, com o armamento estragado e carecendo das noções táticas mais simples. Era preciso completá-los, armá-los, vesti-los, municiá-los, adestrá-los e instruílos.

Queimadas fez-se um viveiro de recrutas e um campo de instrução. Os dias começaram a escoar-se monotonamente em evoluções e manobras, ou exercícios de fogo, numa linha de tiro improvisada num sulco aberto na caatinga próxima. E o entusiasmo marcial dos primeiros tempos afrouxava, molificando na insipidez daquela Cápua invertida, em que bocejavam, remansando, centenares de valentes, marcando passo diante do inimigo...

Dali seguiram, batalhão por batalhão, iludindo em transporte parcial a carência de viaturas, para Monte Santo, onde a situação não variou. Continuaram até meados de junho os mesmos exercícios e a mesma existência aleatória de mais de 3 mil homens em armas, dispostos aos combates mas impotentes para a partida e — registremos esta circunstância singularíssima - vivendo à custa dos recursos ocasionais de um município pobre e talado pelas expedições anteriores.

A custo terminara-se a linha telegráfica de Queimadas, pela comissão de engenheiros militares, dirigida pelo tenente-coronel Siqueira de Meneses. E foi a única coisa apreciável durante tanto tempo perdido. O comandante-em-chefe, sem carretas para o transporte de munições, desapercebido dos mais elementares recursos, quedava-se, sem deliberar, diante da tropa acampada, e mal avitualhada por alguns bois magros e famintos dispersos em torno sobre as macegas secas das várzeas. O deputado do Quartel-Mestre-General não conseguira sequer um serviço regular de comboios, que partindo de Queimadas abastecessem a base das operações, de modo a armazenar reservas capazes de sustentar por oito dias a tropa. De sorte que ao chegar o mês de julho, quando a $2^{\mathrm{a}}$ coluna, atravessando Sergipe, se abeirava de Jeremoabo, não havia em Monte Santo um único saco de farinha em depósito. A penúria e uns como prenúncios de fome condenavam à imobilidade a divisão em que se achava o principal chefe da campanha.

Esta estagnação desalentava os soldados e alarmava o país. Como um diversivo, ou um pretexto de afastar por alguns dias de Monte Santo mil e tantos concorrentes aos escassos recursos da coluna, duas brigadas seguiram em reconhecimentos inúteis até ao Cumbe e Maçacará. Foi o único movimento militar realizado e não teve sequer o valor de aplacar a impaciência dos expedicionários.

Uma delas, a $3^{\text {a }}$ de Infantaria — recém-formada com o $5^{\circ}$ e $9^{\circ}$ Batalhões de Artilharia, porque esta se reconstituíra com a anexação de uma bateria de tiro rápido e com $07^{0}$ destacado da $1^{\mathrm{a}}$ - estava sob o comando de um oficial incomparável no combate, mas de temperamento irrequieto demais para aquela apatia. E ao chegar a Maçacará, depois de prear em caminho alguns cargueiros que demandavam o arraial sedicioso, em vez de volver à base de operações esteve na iminência de seguir, isolada, pela estrada do Rosário, para o centro da luta. O coronel Thompson Flores, planeando este movimento indisciplinado e temerário, mal contido pela sua oficialidade, delatava, bem que exagerada pelo seu forte temperamento nervoso, a situação moral dos combatentes. Revoltava-os a todos a imobilidade em que se amortecera o arranco marcial dos primeiros dias.

Estremeciam muitos imaginando o desapontamento de receberem, de improviso, a nova da tomada de Canudos pelo general Savaget. Calculavam os efeitos daquela dilação ante a opinião pública ansiosa por um desenlace; e consideravam quão útil se tornaria ao adversário alentado por três vitórias aquele armistício de três meses.

Esta última consideração era capital.

\section{Não há um plano de campanha}

O general Artur Oscar determinou de agir traçando, a 19 de junho, a ordem do dia da partida na qual "deixa à imparcialidade da História a justificativa de tal demora”.

Sem o laconismo próprio de tais documentos, o general, após augurar inevitável vitória sobre a gente de Antônio Conselheiro, "o inimigo da República”, aponta às tropas os perigos que as saltearão à entrada do sertão, 
onde “o inimigo as atacará pela retaguarda e flancos” no meio daquelas "matas infelizes” eivadas "de caminhos obstruídos, trincheiras, surpresas de toda a sorte, e tudo quanto a guerra tem de mais odioso".

Em que pese à sua literatura alarmante, eram dados verdadeiros estes. A comissão de engenharia realizara reconhecimentos acordes no afirmarem, mais viva, a aspereza do solo, cujos traços topográficos impunham três condições ao favorável sucesso da campanha: forças bem abastecidas, que dispensassem os recursos das paragens pobres; mobilidade máxima; e plasticidade, que as adaptasse bem às flexuras do terreno revolto e agro.

\section{Crítica}

Eram três requisitos essenciais, completando-se. Mas nem um só foi satisfeito. As tropas partiriam da base de operações - à meia ração. Seguiriam chumbadas às toneladas de um canhão de sítio. E avançariam em brigadas cujos batalhões, a quatro de fundo, guardavam esses intervalos de poucos metros.

Persistia a obsessão de uma campanha clássica. Mostram-na as instruções entregues, dias antes, aos comandantes de corpos. Resumo de uns velhos preceitos que cada um de nós, leigos no ofício, pode encontrar nas páginas do Vial, o que em tal documento se depara — é a teimosia no imaginar, impactas, dentro de traçados gráficos, as guerrilhas solertes dos jagunços.

O chefe expedicionário alongou-se exclusivamente numa distribuição de formaturas. Não se preocupou com o aspecto essencial de uma campanha que, reduzida ao domínio estrito da tática - se resumia no aproveitamento do terreno e numa mobilidade vertiginosa. Porque a sua tropa mal distribuída ia seguir para o desconhecido, sem linhas de operações - adstrita aos reconhecimentos ligeiros feitos anteriormente, ou dados colhidos, de relance, por oficiais das outras expedições — e nada existe de prático naquelas instruções sobre serviço de segurança na vanguarda e nos flancos. Em compensação ostenta a preocupação da ordem mista, em que os corpos, na emergência da batalha, se deveriam desenvolver, com as distâncias regulamentares, de modo que cada brigada, desarticulando-se em campo raso, pudesse, geometricamente - cordões de atiradores, linhas de apoio e reforço, e reservas — agir com a segurança mecânica estatuída pelos luminares da guerra. E o chefe expedicionário citou, a propósito, Ther Brun. Não quis inovar. Não imaginou que o frio estrategista invocado, um gênio que não valia na ocasião as ardilezas de um capitão-do-mato, capitularia os dispositivos preceituados de idealização sem nome, nas guerras sertanejas - guerras à gandaia, sem programas rígidos, sem regras regulares, rodeadas de mil casos fortuitos, e aos recontros súbitos em todas as voltas dos caminhos ou tocaias em toda a parte.

Copiou instruções que nada valiam, porque estavam certas demais. Quis desenhar o imprevisto. A luta, que só pedia um chefe esforçado e meia dúzia de sargentos atrevidos e espertos, ia iniciar-se enleada em complexa rede hierárquica - uns tantos batalhões maciços entalando-se em veredas flexuosas e emperrados diante de adversários fugitivos e bravos. Prendeuse-lhe, além disto, às ilhargas, a mola de aço de um Whitworth de 32, pesando 1.700 quilos! A tremenda máquina, feita para a quietude das fortalezas costeiras - era o entupimento dos caminhos, a redução da marcha, a perturbação das viaturas, um trambolho a qualquer deslocação vertiginosa de manobras. Era, porém, preciso assustar os sertões com o monstruoso espantalho de aço, ainda que se pusessem de parte medidas imprescindíveis.

Exemplifiquemos: as colunas partiram da própria base das operações em situação absolutamente inverossímil - à meia ração. Marcharam em desdobramentos que, como veremos em breve, não as forravam dos assaltos. Por fim, não tiveram a garantia de uma vanguarda eficaz, de flanqueadores capazes de as subtraírem a surpresas.

Os que as acompanhavam nada valiam. Tinham que marchar, ladeando o grosso da tropa por dentro das caatingas, e estas tolhiam-lhes o passo. Soldados vestidos de pano, rompendo aqueles acervos de espinheirais e bromélias, mal arriscariam alguns passos, deixando por ali, esgarçados, os fardamentos, em tiras.

Entretanto, poderiam avançar adrede predispostos à remoção de tais inconvenientes. Bastava que fossem apropriadamente fardados. O hábito dos vaqueiros era um ensinamento. O flanqueador devia meter-se pela caatinga, envolto na armadura de couro do sertanejo - garantido pelas alpercatas fortes, pelos guarda-pés e perneiras, em que roçariam 
inofensivos os estiletes dos xiquexiques, pelos gibões e guarda-peitos, protegendo-lhe o tórax, e pelos chapéus de couro, firmemente apresilhados ao queixo, habilitando-o a arremessar-se, imune, por ali adentro. Um ou dois corpos assim dispostos e convenientemente adestrados acabariam por copiar as evoluções estonteadoras dos jagunços, sobretudo considerando que ali estavam, em todos os batalhões, filhos do Norte, nos quais o uniforme bárbaro não se ajustaria pela primeira vez.

Não seria, isto, excessiva originalidade. Mais extravagantes são os dólmãs europeus de listas vivas e botões fulgentes, entre os gravetos da caatinga decídua. Além disto, atestam-no os nossos admiráveis patrícios dos sertões, aquela vestidura bizarra, capaz, em que pese ao seu rude material, de se afeiçoar aos talhos de uma plástica elegante, parece que robustece e enrija. É um mediador de primeira ordem ante as intempéries. Atenua o calor no estio, atenua o frio no inverno; amortece as mais repentinas variações de temperatura; normaliza a economia fisiológica e produz atletas. Harmoniza-se com as maiores vicissitudes da guerra. Não se gasta; não se rompe. Depois de um combate longo, o lutador exausto tem o fardamento intacto e pode repousar sobre uma moita de espinhos. Ao ressoar de um alarma súbito, apruma-se, de golpe, na formatura, sem uma prega na sua couraça flexível. Marcha sob uma chuva violenta e não tirita encharcado; depara, adiante, um ervaçal em chamas e rompe-o aforradamente; entolha-se-lhe um ribeirão correntoso e vadeia-o, leve, da véstia impermeável.

Mas isto seria uma inovação extravagante. Temeu-se colar à epiderme do soldado a pele coriácea do jagunço. A expedição devia marchar corretíssima. Corretíssima e fragílima.

Partira em primeiro lugar, no dia 14, a comissão de engenharia, protegida por uma brigada. Levava uma tarefa árdua: afeiçoar à marcha as trilhas sertanejas; e retificá-las, ou alargá-las, ou nivelá-las, ou ligá-las por estivas e pontilhões ligeiros, de modo que em tais veredas, cindidas de boqueirões e envesgando pelos morros, passasse aquela artilharia imprópria — as baterias de Krupp, alguns canhões de tiro rápido, e o aterrador 32, que por si só requeria estrada de rodagem, consolidada e firme.
Esta estrada foi feita. Abriu-a num belo esforço, e com tenacidade rara, a comissão de engenharia, desenvolvendo-a ao alto da Favela, num percurso de quinze léguas.

\section{A comissão de engenharia}

Para este trabalho notável houve um chefe - o tenente-coronel Siqueira de Meneses.

\section{Siqueira de Meneses}

Ninguém até então compreendera com igual lucidez a natureza da campanha, ou era mais bem aparelhado para ela. Firme educação teórica e espírito observador tornavam-no guia exclusivo daqueles milhares de homens, tateantes em região desconhecida e bárbara. Percorrera-a quase só, acompanhado de um ou dois ajudantes, em todos os sentidos. Conhecia-a toda; e infatigável, alheio a temores, aquele campeador, que se formara fora da vida dos quartéis, surpreendia os combatentes mais rudes. Largava pelas chapadas amplas, perdia-se no deserto referto de emboscadas, observando, estudando e muitas vezes lutando. Cavalgando animais estropiados, inaptos a um meio galope frouxo, afundava nos grotões; varava-os; galgava os cerros abruptos, em reconhecimentos perigosos; e surgia no Caipã, em Calumbi e no Cambaio, em toda a parte, mais preocupado com a carteira de notas e os croquis ligeiros do que com a vida.

Atraía-o aquela natureza original. A sua flora estranha, o seu facies topográfico atormentado, a sua estrutura geognóstica ainda não estudada antolhavam-se-lhe, largamente expandidas, em torno, escritas numa página revolta da terra que ainda ninguém lera. $\mathrm{E}$ o expedicionário destemeroso fazia-se, não raro, o pensador contemplativo. Um pedaço de rocha, o cálice de uma flor ou um acidente do solo, despeavam-no das preocupações da guerra, levando-o à região remansada da ciência.

Conheciam-no os vaqueiros amigos das cercanias e por fim os próprios jagunços. Assombrava-os aquele homem frágil, de fisionomia nazarena, que, apontando em toda a parte com uma carabina à bandoleira e um podômetro preso à bota, lhes desafiava a astúcia e não tremia ante as 
emboscadas e não errava a leitura da bússola portátil entre os estampidos dos bacamartes.

Por sua vez o comandante-em-chefe avaliara o seu valor. O tenentecoronel Meneses era o olhar da expedição. Oriundo de família sertaneja do Norte e tendo até próximos colaterais entre os fanáticos, em Canudos, aquele jagunço alourado, de aspecto frágil, física e moralmente brunido pela cultura moderna, a um tempo impávido e atilado - era a melhor garantia de uma marcha segura. E deu-lhe um traçado que surpreendeu os próprios sertanejos.

\section{Estrada de Calumbi}

Entre os caminhos que demandavam Canudos, dois, o do Cambaio e o de Maçacará, haviam sido trilhados pelas expedições anteriores. Restava o de Calumbi, mais curto e em muitos pontos menos impraticável, sem as trincheiras alterosas do primeiro ou vastos plainos estéreis do último. Tais requisitos faziam crer que fosse inevitavelmente escolhido. Neste pressuposto os sertanejos fortificaram-no de tal maneira que a marcha da expedição por ali acarretaria desastre completo, muito antes do arraial.

O plano esboçado pela comissão de engenharia evitou-o, norteando a estrada mais para o levante, beirando os contrafortes de Aracati.

\section{A marcha para Canudos}

Por ali avançaram, parceladamente, as brigadas.

A de artilharia, decampando de Monte Santo, a 17, deparou, logo aos primeiros passos, dificuldades sérias. Enquanto os canhões mais ligeiros chegavam, transcorridos dez quilômetros, ao Rio Pequeno, o obstruente 32 ficara distanciado de uma légua. Pela estrada, escorregadia e cheia de tremedais, ronceavam penosamente as vinte juntas de bois que o arrastavam, guiadas por inexpertos carreiros, uns e outros pouco afeitos àquele gênero de transportes, inteiramente novo e em que toda a sorte de empecilhos surgiam a todo o instante e a cada passo, nas flexuras fortes do caminho, na travessia das estivas mal feitas, ou em repentinos desnivelamentos, fazendo adernar a máquina pesadíssima.
Somente no dia 19, à tarde, gastando três dias para percorrer três léguas, chegou o canhão retardatário ao Caldeirão Grande, permitindo que se reorganizasse a brigada de artilharia que, juntamente com a $2^{\mathrm{a}}$, de Infantaria, tendo à vanguarda o $25^{\circ}$ Batalhão do tenente-coronel Dantas Barreto, prosseguiria na manhã subsequente para a Gitirana, distante oito quilômetros da estação anterior, com a mesma marcha fatigante e remorada.

Naquele mesmo dia saíra de Monte Santo o comandante geral e o grosso da coluna constituído pelas $1^{\mathrm{a}}$ e $3^{\mathrm{a}}$ Brigadas, com o efetivo de 1.933 soldados.

Toda a expedição em caminho, forte de uns 3 mil combatentes, avançou até ao Aracati, 46 quilômetros além de Monte Santo, de idêntico modo: as grandes divisões progredindo isoladas, ou concentrando-se e dispersando-se logo, distanciando-se às vezes demais, contrastando sempre a investida ligeira da vanguarda com o tardo caminhar da artilharia.

\section{O 5. Corpo de Polícia Baiana}

Mais afastado ainda, no coice de toda a tropa, ia o grande comboio geral de munições, sob o mando direto do deputado do Quartel-MestreGeneral, coronel Campelo França, e guarnecido com 432 praças, o $5^{\circ}$ Corpo de Polícia Baiana - o único entre todos que se talhara pelas condições da campanha. Recém-formara-se com sertanejos engajados nas regiões ribeirinhas do S. Francisco. Mas não era um batalhão de linha, como não era um batalhão de polícia. Aqueles caboclos rijos e bravos, joviais e bravateadores, que mais tarde, nos dias angustiosos do assédio de Canudos, descantariam, ao som dos machetes, modinhas folgazãs, debaixo de fuzilarias rolantes - eram um batalhão de jagunços. Entre as forças regulares de um e outro matiz, imprimiam o traço original da velha bravura a um tempo romanesca e bruta, selvagem e heroica, cavaleira e despiedada, dos primeiros mestiços, batedores de bandeiras. Eram o temperamento primitivo de uma raça, guardado, intacto, no insulamento das chapadas, fora da intrusão de outros elementos e aparecendo, de chofre, com a sua feição original; misto interessante de atributos antilógicos, em que uma ingenuidade adorável e a lealdade levada até ao sacrifício, e o heroísmo distendido até à barbaridade, se confundem e se revezam, indistintos. Vê-loemos ao diante. 


\section{Alteração da formatura}

O $5^{\circ}$ Corpo e o comboio, partindo por último, de Monte Santo, à reçaga da expedição, quando deviam centralizá-la, seguiam, ao cabo, completamente isolados. E isto acontecia aos demais batalhões. A despeito da formatura estatuída, verificara-se logo a impossibilidade de uma concentração imediata, na emergência da batalha. Adstrito ao trabalho dos sapadores, todo o trem da artilharia ficava, por vezes, longamente separado do resto da coluna, como um trambolho obstruente entre a vanguarda e o comboio geral. De sorte que se, por um golpe de ousadia, os jagunços, em trechos adrede escolhidos, houvessem salteado o último, o refluxo da primeira, correndo em auxílio, estacaria de encontro às baterias engasgadas nas veredas estreitas.

Revela-o o roteiro pormenorizado da marcha. Enquanto o grosso da coluna decampava, no alvorecer de 21, do Rio Pequeno, pouco mais de uma légua de Monte Santo, e chegava, seriam nove horas da manhã, ao Caldeirão Grande, depois de caminhar duas léguas, já desta escala largara à retaguarda da artilharia o canhão 32, protegido pela Brigada Medeiros. Na mesma ocasião, mais avantajada, a Brigada Gouveia atingia a Gitirana, à noite, onde já se achavam a comissão de engenheiros e o general Artur Oscar, que até lá fora, escoteiro, seguido de um piquete de vinte praças de cavalaria e do $9^{\circ}$ de Infantaria. Considerando-se que o comboio dirigido pelo coronel Campelo França e protegido pelo $5^{\circ}$ de Polícia ficara à retaguarda, vê-se que a tropa se espalhara em longura de quase quatro léguas, violando-se inteiramente as instruções preestabelecidas.

No amanhecer do dia 22, enquanto o general Barbosa, que permanecera o resto do dia anterior em Caldeirão, levantava acampamento seguindo para Gitirana, daí partia o comandante geral com a Primeira Brigada, o $9^{\circ}$ Batalhão da $3^{\mathrm{a}}$ e $25^{\circ}$ da 2 , a ala de cavalaria do major Carlos de Alencar e a artilharia, levando o dispositivo prefixado: na frente o $14^{\circ} \mathrm{e}$ $30^{\circ}$ Batalhões, no centro a cavalaria e a artilharia; depois dois outros corpos, o $9^{\circ}$ e o $25^{\circ}$. Ora, enquanto o comandante geral seguia rapidamente naquele dia, chegando em pouco tempo com a vanguarda a Juá, 7.600 metros além de Gitirana, a artilharia imobilizava-se nesta última escala aguardando que a comissão de engenheiros ultimasse a abertura de picadas e trabalhos de sapa; e, como o grosso das forças vinha ainda pela estrada do Caldeirão, estas mais uma vez se subdividiam forçadamente, ficando em condições desvantajosas na emergência de um assalto, porque não vinham adrede dispostas a afastamentos tão largos, que deviam ter sido de antemão estabelecidos, realizando-se não como um vício de mobilidade mas como requisito tático indispensável.

As brigadas reuniram-se, por fim, na noite daquele dia, em Juá. Ali chegou, às 6 horas, logo após a artilharia, o resto da coluna composta dos $5^{\circ}, 7^{\circ}, 15^{\circ}, 16^{\circ}$ e $27^{\circ}$ corpos de infantaria. Executava-se o comboio, retardado num trecho qualquer dos caminhos.

Daquele ponto seguiram os dois generais, na manhã de 23, para Aracati, 12.800 metros na frente, fazendo a vanguarda os batalhões do coronel Gouveia. Mas a artilharia, protegida pelos do coronel Medeiros, só se moveu ao meio-dia, depois que os engenheiros, apoiados pela Brigada Flores, executaram penosíssimos trabalhos de reparos.

Pormenorizamos, miudeando-a aos menores incidentes, esta marcha, para que se revelem as condições excepcionais que a rodearam.

Depois da partida de Juá e atingida a velha fazenda do Poço, totalmente em ruínas, sobreveio incidente indicador do quanto era conhecido o terreno em que se avançava.

\section{Incidentes}

Ao invés de prosseguirem em rumo para a direita - buscando a fazenda do Sítio, de um sertanejo aliado, Tomás Vila-Nova, inteiramente dedicado à nossa gente - entraram os sapadores por um desvio, a esquerda. Quando já iam longe, depois de algumas horas de trabalho, reconheceu o tenente-coronel Siqueira de Meneses a impossibilidade de afeiçoar os caminhos com a presteza necessária. "Tais eram o grande movimento de terras a fazer-se, o cerrado da caatinga, os pesados lajedos a remover-se, além dos acidentes do terreno para a descida e subida dos veículos”. Abandonando então todo o trabalho feito, procurou o sítio de Vila-Nova. Esclarecido por este, atacou à tarde a nova vereda que, embora alongando a distância, tinha melhores condições de viabilidade. A artilharia por ali só avançou ao cair da tarde, passando pelo sítio dos Pereiras. Foi acampar a meia-noite na lagoa da Laje, dois quilômetros aquém de Aracati, 
onde já estava havia muito toda a coluna. Ficara ainda mais à retaguarda, com a $3^{\text {a }}$ Brigada, o moroso 32, à borda a pique de um ribeirão, o dos Pereiras, que o adiantado da noite obstara se pudesse atravessar.

Entrava-se, no entanto, na zona perigosa. Nesse dia, na lagoa da Laje, o piquete do comando geral, guiado por um alferes, surpresara alguns rebeldes que destelhavam a casa ali existente. O recontro foi rápido. Os sertanejos, de surpresa acometidos por uma carga, fugiram sem replicar. Um único ficou. Estava sobre o telhado levadio e ao descer viu-se circulado. Reagiu apesar de ferido. Afrontou-se com o adversário mais próximo, um anspeçada; desmontou-o; e arrancou-lhe das mãos a clavina, derreando-o com ela a coronhadas. Encostou-se depois à parede do casebre e fez frente aos soldados, girando-lhes à cabeça a arma, em molinete. Batido, porém, de toda a banda, baqueou, exausto e retalhado. Mataram-no. Era a primeira façanha, exígua demais para tanta gente.

\section{Suceder-se-lhe-iam outras.}

No dia 24 agravou-se a marcha. A coluna, que decampara de Aracati ao meio-dia, porque teve de aguardar a vinda dos retardatários da véspera, endireitou, unida, para Juetê, distante 13.200 metros — para mais uma vez se subdividir.

\section{Os caminhos pioravam.}

Tornou-se necessário, além dos trabalhos de sapa, abrir mais de uma légua de picada contínua através de uma caatinga feroz que naquele trecho justifica bem o significado da denominação indígena do lugar ${ }^{1}$.

Relata o chefe desse trabalho memorável ${ }^{2}$ :

Ao xiquexique, palmatória, rabo-de-raposa, mandacarus, croás, cabeça-de-frade, culumbi, cansação, favela, quixaba e a respeitabilíssima macambira, reuniu-se o muito falado e temido cunanã, espécie de cipó com aspecto arborescente, imitando no todo a uma planta cultivada nos jardins, cujas folhas são cilíndricas. A poucos centímetros do chão o tronco divide-se em muitos galhos, que se multiplicam numa profusão admirável, formando uma grande

\footnotetext{
${ }^{1}$ Ju-etê - espinho grande - por extensão: espinheiral, grande espinheiro.

2 Tenente-Coronel Siqueira de Meneses. Artigos publicados no País, com o pseudônimo Hoche.
}

copa, que se mantém no espaço por seus próprios esforços ou favorecido por algumas plantas que vegetam de permeio. Estende suas franças de folhas cilíndricas com oito caneluras e igual número de filetes em gume e pouco salientes, semelhando-se a um enorme polvo de milhões de antenas, como elas flexíveis e elásticas, cobrindo, não raras vezes, considerável superfície do solo, emaranhando-se, por entre a esquisita e raquítica vegetação destas paragens, em uma trama impenetrável. A foice mais afiada dos nossos soldados do contingente de engenharia ("chineses” na frase gaiata dos companheiros dos corpos combatentes) e polícia dificilmente as decepava nos primeiros golpes, oferecendo, portanto, resistência inesperada ao empenho que todos traziam em ir por diante. Nesse labirinto de nova espécie, teve a comissão de engenharia em poucas horas de abrir mais de seis quilômetros de estrada, tendo ao encalço a artilharia, que a atropelava impaciente. $\mathrm{O}$ ingente esforço desenvolvido pelos distintos e patriotas republicanos, empenhados neste pesadíssimo labor, não impediu que a noite os viesse surpreender, antes de chegar à espécie de clareira denominada pelo povo do lugar de Queimadas, onde esta vegetação traiçoeira desaparecia de sua frente, como que tomada de medo. Antes que o desânimo, o cansaço e o sono se apoderassem dos nossos soldados resignados e trabalhadores, a citada comissão representada nesta ocasião pelo chefe, tenentes Nascimento e Crisanto, alferes Ponciano, Virgílio e Melquíades, os dois últimos da polícia, o terceiro auxiliar e o quarto comandante do contingente de engenharia, pois o capitão Coriolano e tenente Domingos Ribeiro achavam-se mais atrás em outros trabalhos, tomou o alvitre de mandar acender, já escura a noite, de distância em distância, grandes fogueiras para à sua luz prosseguirem os obreiros da boa causa da Pátria.

Assim concluiu-se com alegria geral e contentamento, das oito para nove horas da noite, este último trecho, em que a cunanã se dissolveu em mais benigna vegetação ao sair das Queimadas de que já falamos. O canhão 32, não podendo vencer os obstáculos avolumados pela noite, ficou dentro da picada até o dia seguinte e com ele o Dr. Domingos Leite, que trabalhava desde o Rio Pequeno com uma turma de "chineses” no empenho de levá-lo a Canudos.

Pouco depois de nove horas estava a comissão reunida e acampada na clareira debaixo de chuvas torrenciais, que se prolongaram até ao dia seguinte, a todos contrariando, a todos causando mal-estar e aborrecimentos. Aí também acampou a Brigada de Artilharia, o $16^{\circ} \mathrm{e}$ 
o $25^{\circ}$ Batalhões de Infantaria, tendo-se conservado em proteção ao 32 o $27^{\circ}$ que dormiu na picada. Foi magnífico, esplêndido mesmo, o espetáculo que a todos vivamente impressionou, vendo a artilharia com seus metais faiscantes e polidos, altiva de sua força soberana, atravessar garbosa e imponente, como rainha do mundo, por entre os fantásticos clarões de grandes fogos, acesos no deserto, como que pelo gênio da liberdade, para mostrar-lhe o caminho do dever, da honra e da glória.

Durante este tempo chegava a Juetê, onde pernoitou, o general Oscar, com o estado-maior e o piquete de cavalaria. Ao passo que o general Barbosa, com a $1^{\text {a }}$ e $3^{\text {a }}$ Brigadas, endireitava para a fazenda do Rosário, 4.700 metros na frente.

Ali chegou na antemanhã seguinte o comandante geral; e mais tarde o resto da divisão, tendo-se tornado, ainda, necessário taludar as ribanceiras do Rio Rosário para que o atravessasse a artilharia.

\section{Um guia temeroso: Pajeú}

O inimigo apareceu outra vez. Mas célere, fugitivo. Algum piquete que bombeava a tropa. Dirigia-o Pajeú. O quadrilheiro famoso visara, à primeira vista, um reconhecimento. Mas, de fato, como o denunciaram ulteriores sucessos, trazia objetivo mais inteligente: renovar o delírio das cargas e um marche-marche doido, que tanto haviam prejudicado a expedição anterior. Aferrou a tropa num tiroteio rápido, de flanco, fugitivo, acompanhando-a velozmente por dentro das caatingas. Desapareceu. Surgiu, logo depois, adiante. Caiu num arremesso vivo e fugaz sobre a vanguarda, feita neste dia pelo $9^{\circ}$ de Infantaria. Passou, num relance, acompanhado de poucos atiradores, por diante, na estrada. Não foi possível distingui-los bem. Trocadas algumas balas, desapareceram. Ficou aprisionado e ferido um curiboca de doze ou quatorze anos, que nada revelou no interrogatório a que o sujeitaram.

\section{No Rosário}

A tropa acampou, sem outros sucessos, naquele sítio.

Reuniram-se os combatentes, exceto a $3^{\mathrm{a}}$ Brigada que se avantajara até às Baixas, seis quilômetros na frente.

O comandante-em-chefe enviou, ao general Savaget, um emissário reiterando o compromisso anterior de se encontrarem, a 27, nas cercanias de Canudos.

Decamparam a 26, seguindo para o Rancho do Vigário dezoito quilômetros mais longe, após pequena alta nas Baixas.

Estavam a cerca de oitenta quilômetros de Monte Santo. Em plena zona perigosa. A breve troca de balas da véspera pressupunha eventualidades de combates. Talvez, esclarecidos pelo reconhecimento feito, os jagunços se dispusessem a refregas mais sérias. Denunciava-os, como sempre, de algum modo, a fisionomia da terra, a conformação do terreno que dali por diante se acidenta, eriçado de cômoros escalvados, até às Baixas, onde se alcantila a Serra do Rosário, de flancos duros e vegetação rara.

As tropas iam escalar pelo sul a antemural que circunscreve Canudos. Progrediam cautelosas na rota. Não ressoaram mais as cornetas. Formados cedo, os batalhões marcharam até ao sopé da serrania. Galgaram-na. Derivaram, depois, na descida pelo boqueirão que a separa do Rancho do Vigário.

Toda a coluna se subdividiu ainda, largamente fracionada: enquanto a vanguarda atingia, ao entardecer, o pouso, a artilharia ligeira, que abandonara com os engenheiros o ronceiro 32, vinha pelos primeiros recostos da vertente e aquele ascendia vagarosamente, do outro lado, à feição dos trabalhos de sapa que lhe estradavam as ladeiras. A noite, e com a noite uma chuva torrencial batida de ventanias violentas, desceu sobre os expedicionários que, em tais condições, seriam facilmente desbaratados pelas guerrilhas dos adversários, velhos conhecedores do terreno. Não o fizeram. Tinham mais bem disposta outra posição, como veremos. Deixaram também em paz o comboio que seguia, perdido à retaguarda, pela estrada de Juetê. Haviam afrouxado os animais de tiro; e toda a carga de 53 
carroças e sete grandes carros de bois passara, subdividida, para as costas dos rijos sertanejos do $5^{\circ}$ Batalhão da Polícia.

Passou, entretanto, em paz, a noite. No dia subsequente, 27, emprazado para o encontro temeroso das duas colunas - apisoando ovantes os escombros do arraial investido - pôs-se tudo em movimento para a última jornada. E na alacridade singular sulcada de impaciências, de apreensões, e de entusiasmo vibrante, que antecede a vinda da batalha, ninguém cogitou nos companheiros remorados.

As brigadas abalaram, deixando de todo esquecido, ao longe, o comboio desguarnecido por completo, porque os seus soldados, já arcando sob grandes fardos, já auxiliando os raros muares que ainda suportavam as cargas, estavam nas mais impróprias condições para o mais ligeiro recontro.

Seguiram as brigadas: na frente a do coronel Gouveia com duas bocas de fogo; no centro a do coronel Olímpio da Silveira e a cavalaria; e depois, sucessivamente, as dos coronéis Thompson Flores e Medeiros. Atravessaram sobre dois pontilhões ligeiros o riacho do Angico. Estiraramse vagarosamente, estrada em fora, numa linha de dez quilômetros.

Rompia a marcha o $25^{\circ}$ Batalhão, ladeado de dois pelotões de flanqueadores, inúteis, mal rompendo a golpes de facão as galhadas.

\section{Passagem nas Pitombas}

De sorte que os jagunços os assaltaram, de surpresa, antes da chegada, ao meio-dia, no Angico. Foi mais sério o ataque, ainda que não valesse o nome de combate, que mais tarde lhe deram. Pajeú congregara os piquetes, que se sucediam daquele ponto até Canudos, e viera, de soslaio, sobre a força. Esta, sobre uma rampa escampada, ficou em alvo ante os tiros por elevação dos sertanejos imperfeitamente distinguidos na orla do matagal, embaixo; mas replicou com firmeza, perdendo apenas dois soldados, um morto e outro ferido. E continuou avançando em ordem, a passo ordinário, até ao sítio memorável de Pitombas, onde houvera o primeiro encontro de Moreira César com os fanáticos.

O lugar era lúgubre.

\section{Recordações cruéis}

Despontavam em toda a banda recordações cruéis: mulambos já incolores, de fardas, oscilando à ponta dos esgalhos secos; velhos selins, pedaços de mantas e trapos de capotes esparsos pelo chão, de envolta com fragmentos de ossadas. À margem esquerda do caminho, erguido num tronco - feito um cabide em que estivesse dependurado um fardamento velho - o arcabouço do coronel Tamarindo, decapitado, braços pendidos, mãos esqueléticas calçando luvas pretas...

Jaziam-lhe aos pés o crânio e as botas.

E do correr da borda do caminho ao mais profundo das macegas, outros companheiros de infortúnio: esqueletos vestidos de fardas poentas e rotas, estirados no chão, de supino, num alinhamento de formatura trágica; ou desequilibradamente arrimados aos arbustos flexíveis, que, oscilando à feição do vento, lhes davam singulares movimentos de espectros delatavam demoníaca encenação adrede engenhada pelos jagunços. Nada lhes haviam tirado, excluídas as munições e as armas. Uma praça do $25^{\circ}$ encontrou, no lenço envolto na tíbia descarnada de um deles, um maço de notas somando quatro contos de réis - que o adversário desdenhara, como a outras coisas de valor para ele despiciendas.

Os combatentes, assombrados, mal atentaram naquele cenário; porque o inimigo continuava aferroando-os, de esguelha. Repelido no recontro anterior, depois que o contornara pela direita uma companhia do $25^{\circ}$ dirigida pelo capitão Trogílio de Oliveira, recuava, atacando.

O $25^{\circ}$ e logo após o $27^{\circ}$, do major Henrique Severino da Silva, prosseguiram repelindo-o, até ao Angico.

Era meio-dia. A batalha parecia iminente. Em vários pontos, partindo dos flancos e da frente, estalavam tiros destacados. O comandante geral tomou as disposições mais convenientes para repelir o adversário que tudo denotava ir aparecer, rodeando-o. Um piquete de cavalaria dirigido pelo alferes Marques da Rocha, de seu estado-maior, enviado a bater o matagal, à esquerda, revolveu-o, entretanto, inutilmente. A avançada prosseguiu.

Duas horas depois, ao transpor o general o teso de uma colina o ataque recrudesceu, de súbito. Fizeram-se alguns disparos de Krupp. Um 
sargento de cavalaria e algumas praças arrojaram-se temerariamente na caatinga. Varrem-na. A marcha continuou. Na frente o $25^{\circ}$ vanguardeado por uma companhia de exploradores, e sucessivamente seguidos do $27^{\circ}$ e o $16^{\circ}$, replicava aos tiroteios escassos e acelerava a investida.

Aproximava-se a noite. A vanguarda arremeteu com as últimas ladeiras vivas do caminho, nas Umburanas. Subiu-as ofegante, sem vacilar na marcha. Repeliu mais uma vez o ataque sério, pelo flanco.

\section{E vingou a montanha.}

No último passo da ascensão se lhe antolhou um plano levemente inclinado, entre duas largas ondulações, fechado adiante por alguns cerros desnudos.

Era o alto da Favela.

\section{O alto da Favela}

Naquele ponto este morro lendário é um vale. Subindo-se tem-se a impressão imprevista de se chegar numa baixada.

Parece que se desceu. Toda a fadiga da ascensão difícil se volve em penoso desapontamento ao viajor exausto. Constringe-se o olhar repelido por toda a sorte de acidentes. Ao contrário de uma linha de cumeadas, depara-se, no prolongamento do caminho do Rosário, um talvegue, um sulco extenso, espécie de calha desmedida trancada, transcorridos trezentos metros, pela barragem de um cerro.

Atingindo este, veem-se-lhe aos lados, esbotenando-lhes os flancos e corroendo-os, fundos rasgões de enxurros que drenam a montanha. Por um deles, o da direita, se enfia, entalando-se em passagem estreita de rampas vivas e altas, quase verticais, lembrando restos de antigos túneis, aquele caminho, descendo, em desnivelamentos fortes. À esquerda outra depressão, terminando na encosta suave de um morro, o do Mário, se dilata na extensão maior de norte a sul, fechando-se, naquele primeiro rumo, ante outro cerro, que oculta o povoado e tomba, de chofre, pelo outro, em boqueirão profundo até ao leito do Umburanas. À frente, em nível inferior, a Fazenda Velha. O pequeno Serrote dos Pelados cai logo, em seguida, em declive, até o Vaza-Barris, embaixo. E para todos os quadrantes — para leste, buscando o vale do Macambira, aquém das cumeadas do Cocorobó e a estrada de Jeremoabo que o atravessa; para o norte, derivando para a vasta planície ondeada; para o ocidente, procurando os leitos dos pequenos rios, o Umburanas e o Mucuim perto do extremo da estrada do Cambaio; para todos os lados, o terreno descamba com o mesmo facies que lhe imprimem sucessivos cômoros empolando-se numa confusão de topos e talhados. Tem-se a imagem real de uma montanha que desmorona, avergoada pelas tormentas, escancelando-se em gargantas, que as chuvas torrenciais de ano a ano reprofundam, sem o abrigo de vegetação que lhe amorteça a crestadura dos estios e as erosões das torrentes.

Porque o morro da Favela, como os demais daquele trato dos sertões, não tem nem mesmo o revestimento bárbaro da caatinga. É desnudo e áspero. Raros arbúsculos, esmirrados e sem folhas, raríssimos cereus ou bromélias esparsas, despontam-lhe no cimo sobre o chão duro, entre as junturas das placas xistosas justapostas em planos estratigráficos, nitidamente visíveis, expondo, sem o disfarce da mais tênue camada superficial, a estrutura interior do solo. Entretanto, embora desabrigado, quem o alcança pelo sul não vê logo o arraial, ao norte. Tem que descer, como vimos, em suave declive, a larga plicatura em que se arqueia, em diedro, a montanha, numa selada entre lombas paralelas.

\section{Fuzilaria}

Por ali enveredou, ao anoitecer, a testa da coluna e uma bateria de Krupp, seguidas do resto da $2^{\mathrm{a}}$ Brigada e da $3^{\mathrm{a}}$, ficando a $1^{\mathrm{a}}$ e o grosso da tropa retardados à retaguarda. Mas deram poucos passos mais. O tiroteio frouxo, que até então acompanhara os expedicionários, progredira num crescendo contínuo, à medida que se realizava a ascensão, transmudando-se ao cabo, no alto, em fuzilaria furiosa.

E desencadeou-se uma refrega original e cruenta.

Não se via o inimigo - encafurnado em todas as socavas, metido dentro das trincheiras-abrigos, que minavam as encostas laterais, e encoberto nas primeiras sombras da noite que descia.

As duas companhias do $25^{\circ}$ Batalhão suportaram valentemente o choque. Desenvolvendo-se em atiradores avançaram, disparando, ao acaso, 
as armas - enquanto as duas brigadas, que as precediam, se abriram para que passasse a bateria. Esta, jogada violentamente para a frente, arrastada, mais a pulso que pelos muares exaustos e espantados, passou entre elas, em acelerado, ruidosamente. Subiu o cômoro fronteiro. Alinhou-se em batalha, no alto. Desenrolou-se no ar a bandeira nacional. Uma salva de 21 tiros de granadas atroou sobre Canudos...

O general Artur Oscar, a cavalo junto aos canhões, observou pela primeira vez, esbatido no clarão do luar deslumbrante, a misteriosa cidade sertaneja; e teve o mais fugaz dos triunfos na eminência varejada em que se expusera temerariamente.

Porque a situação era desesperadora. A sua tropa, batida por todos os flancos, envolta pelo inimigo a cavaleiro, comprimia-se numa flexura estreita que lhe impedia as manobras.

Se estivesse toda reunida era possível uma solução: prosseguir logo, vencendo a perigosa travessia, e juntar-se ao general Savaget que, depois de uma marcha entrecortada de combates, fizera alto três quilômetros adiante. Não havia, porém, chegado a $1^{\text {a }}$ Brigada, que ficara protegendo a bateria de tiro rápido e o 32; e mais moroso ainda, o comboio ficara no Angico, distanciado de duas léguas.

\section{Crítica}

Aquele plano de campanha dera o único resultado que podia dar. A expedição homogênea que, pelo seu dispositivo inicial, não podia fracionarse, porque vinha adstrita a uma direção única e abastecida por um comboio único, dividira-se precisamente ao chegar ao objetivo da luta. De sorte que a arremetida doida rematada por uma salva real, de balas, sobre Canudos, era a mais contraproducente das vitórias. O chefe expedicionário definiu-a depois como um combate de êxito brilhante, mercê do qual o inimigo fugira, abandonando-lhe a posição expugnada. Entretanto todos os sucessos ulteriores revelaram a ânsia irreprimível da tropa por abandoná-la e o empenho persistente, dos jagunços, em impedir que ela dali saísse.

\section{Trincheiras dos jagunços}

Aquilo era uma armadilha singularmente caprichosa. Quem percorresse mais tarde as encostas da Favela avaliava-a. Estavam minadas. A cada passo uma cava circular e rasa, protegida de tosco espaldão de pedras, demarcava uma trincheira. Eram inúmeras; e volvendo todas para a estrada os planos de fogo quase à flor da terra, indicavam-se adrede dispostas para um cruzamento sobre aquela.

Explicavam-se, assim, os ataques ligeiros, feitos em caminho e a insistência, a partir do Angico, do inofensivo tiroteio em que os sertanejos, salteando e correndo, tinham evidente intuito de atrair a expedição segundo um rumo certo, impedindo-lhe a escolta de qualquer atalho entre tantos que dali por diante levam ao arraial.

Triunfara-lhes o ardil. Os expedicionários, sob o estímulo da ânsia perseguidora contra o antagonista disperso na frente, em fuga, haviam imprudentemente enveredado, sem uma exploração preparatória, pela paragem desconhecida, acompanhando, sem o saberem, um guia ardiloso e terrível, com que contavam — Pajeú...

E tombaram na tocaia com aquele aprumo de triunfadores. Mas a breve trecho o perderam, num tumultuar de fileiras retorcidas, quando, em réplica ao bombardeio que tempesteava a um lado, correu vertiginoso, de extremo e de alto a baixo, nas encostas, incendiando-as, um relampaguear de descargas terríveis e fulminantes, rompendo de centenares de trincheiras, explodindo debaixo do chão como fogaças.

\section{Continua a fuzilaria}

Era um fuzilamento em massa...

Os batalhões surpreendidos fizeram-se multidão atônita, assombrada e inquieta: centenares de homens esbarrando-se desorientadamente, tropeçando nos companheiros que baqueavam, atordoados pelos estampidos, deslumbrados pelos clarões dos tiros, e tolhidos, sem poderem arriscar um passo na região ignota sobre que descera a noite.

A réplica, alvejando as encostas, era inútil. Os jagunços atiravam sem riscos, de cócaras ou deitados no fundos dos fossos, em cuja borda 
estendiam os canos das espingardas; excluindo o alvitre de os desalojar a cargas de baionetas, lançando-as desesperadamente contra os morros, ou de prosseguirem, aventurando-se a piores assaltos e abandonando a retaguarda, restava aos combatentes o de permanecerem a pé firme na posição perigosa aguardando o amanhecer.

\section{Acampamento na Favela}

Esta solução única foi favorecida pelo adversário. O ataque ao fim de uma hora amorteceu-se e afinal cessou inesperadamente. As brigadas acamparam na formatura da batalha. A $2^{\text {a }}$ desenvolveu-se em linhas avançadas, do centro para a direita, tendo à retaguarda a $1^{\mathrm{a}}$; a artilharia alinhou-se próxima, sobre o cerro fronteiro, extremada à direita pela bateria de tiro rápido tendo no centro o Whitworth 32 , que se confiara à guarda do $30^{\circ}$, do tenente-coronel Tupi Caldas. O general, que comandara este batalhão quando coronel, pô-lo em pessoa naquele posto perigoso:

À honra do $30^{\circ}$ entrego a artilharia e fico tranquilo.

$\mathrm{O}$ resto do $5^{\circ}$ Regimento, do major Barbedo, emparcou, desenvolvendo-se para a esquerda, tendo próxima a ala de cavalaria do major Carlos Alencar. Perto da depressão, junto ao Alto do Mário, ponto fraco da posição, a que ulteriores sucessos dariam o nome de Vale da Morte, se adensaram os batalhões do coronel Flores. Numa sanga menos enfiada pelos fogos se improvisou um hospital de sangue. Para lá se arrastaram 55 feridos, que com vinte mortos por ali esparsos, porque não havia como os remover, alteavam a 75 o número de baixas do dia, em pouco mais de uma hora de combate.

Estendeu-se em torno um cordão de sentinelas; e a tropa, comandantes e praças deitados pelo chão na mais niveladora promiscuidade — repousou em paz.

A inopinada quietude do inimigo dera-lhes a ilusão da vitória. Saudaram-na antecipadamente as bandas de música da $3^{\text {a }}$ Brigada, esgotando até desoras um grande repertório de dobrados; e um luar admirável alteou-se sobre os batalhões adormecidos...

Mas era uma placidez enganadora. Os sertanejos haviam conseguido o intento que lhes ditara a astúcia. Tendo arrastado até lá a expedição, restava-lhes, de todo desprotegido, à retaguarda, o comboio de munições de guerra e de boca. No dia imediato assaltariam simultaneamente por dois pontos, na Favela e no Angico - e, ainda quando vitoriosas no primeiro as forças arremetessem com o arraial, alcançá-lo-iam desmuniciadas, inermes.

\section{Canudos}

Esta circunstância não pesou, porém, no ânimo dos que se haviam abeirado tão precipitadamente do centro das operações.

Ao clarear da manhã de 28 , reunidos na posição dominante da artilharia, oficiais e praças, contemplavam, afinal a "caverna dos bandidos", segundo o dizer pinturesco das ordens do dia do comandante-em-chefe.

Canudos crescera ainda, porém tendo apenas mais amplo o aspecto primitivo: a mesma casaria vermelha, de tetos de argila, alargando-se cada vez mais esparsa pelo alto das colinas em torno do núcleo compacto abraçado pela volta viva do rio. Circunvalada nos quadrantes de sudoeste e noroeste por aquele, abrangida ao norte e a leste pelas linhas ondeantes dos cerros, emergia, a pouco e pouco, na claridade daquela hora matinal com a feição perfeita de uma cidadela de expugnação dificílima. Percebia-se que um corpo de exército ao cair no dédalo de sangas, que lhe enrugam em roda o terreno, marcharia como entre galerias estreitas de uma praça de armas colossal. Não havia lobrigar-se um ponto francamente acessível.

A estrada de Jeremoabo entrando, duzentos metros antes, pelo leito seco do Vaza-Barris, metia-se entre duas trincheiras, que lhe orlavam uma e outra margem, mascaradas de sebes contínuas de gravatás bravios. A vereda sagrada de Maçacará - por onde seguia o Conselheiro nas suas peregrinações para o sul - tombando pelos morros, entre os quais se encaixa o Umburanas, era igualmente impraticável. As do Uauá e Várzea da Ema, ao norte, estavam livres, mas exigiam para atingirem-se longa e perigosa marcha contornante.

A igreja nova, quase pronta, alevantava as duas altas torres, assoberbando a casaria humilde e completava a defesa. Enfiava pela frente todos os caminhos, batia o alto de todos os morros, batia o fundo de todos os vales. Não tinha ângulo morto a espingarda do atirador alcandorado em 
suas cimalhas espessas, em que só faltavam planos de fogo de canhoneiras, ou recortes de ameias.

O terreno que na frente da Favela, ao norte, deriva até ao rio, empolado e revolto, abre-se, como vimos, para a esquerda na larga depressão, dando acesso ao morro do Mário e à linha de cumeadas em declive que se dirige para Fazenda Velha.

\section{Ali estava a $3^{\text {a }}$ Brigada, desde cedo, formada em colunas.}

Mais para a direita, dominante, a artilharia. Sucessivamente a $2^{\mathrm{a}}$ e a $1^{\text {a }}$ Brigadas. A tropa amanhecera na formatura da batalha. Atendendo, porém, às vantagens táticas da posição, esta devia principiar e em grande parte sustentar-se com a artilharia, cujo efeito, no bater a tiros mergulhantes o arraial distante 1.200 metros, se acreditou capaz de acarretar em pouco tempo a mais completa vitória.

As esperanças concentraram-se, por isto, no primeiro momento, nas baterias do coronel Olímpio da Silveira.

Eram tão grandes que pouco antes de ser feito o primeiro disparo, às seis horas da manhã, numerosos combatentes de outras armas, aglomerados em volta dos canhões, tinham o papel neutral de espectadores, ansiando por um quadro terrivelmente dramático: Canudos ardendo sob a tunica molesta do canhoneio! Uma população fulminada dentro de 5 mil casebres em ruínas!

Era mais uma ilusão a ser duramente desfeita...

O primeiro tiro partiu, disparando o Krupp da extrema direita. E determinou, de fato, um empolgante lance teatral.

Os jagunços haviam dormido ao lado da tropa, por todas aquelas encostas riçadas de algares e, sem aparecerem, circularam-na para logo de descargas.

\section{Chuva de balas}

Mais tarde, relatando o feito, o chefe expedicionário se confessou impotente para descrever a imensa "chuva de balas que desciam dos morros e subiam das planícies num sibilo horrível de notas”, que atordoavam. Por sua vez o comandante da $1^{\text {a }}$ coluna afirmou em ordem do dia, que durante cinco anos, na guerra do Paraguai, jamais presenciara coisa semelhante.

Realmente, os sertanejos revelaram uma firmeza de tiro surpreendedora. As descargas, nutridas, rolantes e violentíssimas, deflagrando pelos cerros como se as ateasse um rastilho único, depois de abrangerem a tropa desabrigada, bateram, convergentes, sobre a artilharia. Dizimaram-na. Tombaram dezenas de soldados e a metade dos oficiais. Sobre o cerro, varrido em minutos, permaneceu, entretanto, firme, a guarnição rarefeita e no meio dela, atravessando entre as baterias, impassível como se desse instrução num polígono de tiro, um velho de bravura serena e inamolgável - um valente tranquilo, o coronel Olímpio da Silveira. Foi a salvação. Em tal emergência o abandono dos canhões seria o desbarato..

\section{Confusão e desordem}

Vibrara o alarma em todos os corpos. Instintivamente, sem direção fixa e sem ordem de comando, 3 mil espingardas dispararam a um tempo dirigidas contra os morros. Estes fatos passaram em minutos, e em minutos, na área comprimida em que se agitava, inútil, a expedição, viu-se a mais lastimável desordem.

Ninguém deliberava. Todos agiam. Ao acaso, estonteadamente, sem campo para o arremesso das cargas ou para a manobra mais simples, os pelotões englobados atiravam a esmo em pontarias altas, para não se trucidarem mutuamente, contra o inimigo sinistro que os rodeava, intangível, surgindo por toda a parte e por toda a parte invisível. Neste tumulto, a $3^{\text {a }}$ Brigada, no flanco esquerdo, disposta em colunas de batalhões e tendo na vanguarda o $7^{\circ}$, começou a avançar, descendo, na direção da Fazenda Velha, de onde rompiam mais fortes as descargas. Aquele batalhão, que quatro meses antes subira por aquele mesmo caminho em debandada, fugindo e atirando-lhe à margem o cadáver do coronel Moreira César, ia penitenciar-se do desaire. Completando esta circunstância especialíssima, acompanhava-o, logo depois, um sócio de reveses, o $9^{\circ}$. O major Cunha Matos dirigia a vanguarda. Os vencidos da expedição anterior deparavam ensejo raro para a desafronta e tinham um chefe que, sob muitos aspectos, se equiparava ao comandante infeliz que ali tombara - o coronel 
Thompson Flores. Era um lutador de primeira ordem. Embora lhe faltassem atributos essenciais de comando e, principalmente, esta serenidade de ânimo, que permite a concepção fria das manobras dentro do afogueamento de um combate - sobravam-lhe coragem a toda a prova e um quase desprezo pelo antagonista por mais temeroso e forte, que o tornavam incomparável na ação. Demonstrou-o o ataque temerário que realizou. Fê-lo indisciplinadamente autônomo, sem determinação superior e com o intento firme de arrebatar, numa carga única, até à praça das igrejas, vitoriosos, os mesmos soldados que lá se tinham debandado, vencidos, quatro meses antes. A sua brigada investiu, batida em cheio pelos fogos diretos do inimigo entrincheirado; e, quase cem metros da posição primitiva, a vanguarda desenvolveu-se em atiradores. O coronel Flores que, a cavalo, lhe tomara a frente, descavalgou, então, a fim de pessoalmente ordenar a linha de fogo. Por um requinte dispensável, de bravura, não arrancara dos punhos os galões que o tornavam alvo predileto dos jagunços. Ao reatar-se, logo depois, a avançada, baqueou, ferido em pleno peito, morto.

\section{Baixas}

Substituiu-o o major Cunha Matos, que dignamente prosseguiu no movimento imprudentemente planeado, porque o $7^{\circ}$ Batalhão, entre os demais corpos, era o único que não podia recuar naquele terreno. $\mathrm{O}$ seu comando foi, porém, brevíssimo. Desmontado logo por um projetil certeiro, passou-o ao major Carlos Frederico de Mesquita. Este por sua vez foi, adiante, atingido por uma bala, assumindo a direção da brigada um capitão, Pereira Pinto. Era assombroso: o $7^{\circ}$ Batalhão teve em meia hora 114 praças fora de combate, e nove oficiais.

Reduzira-se de um terço. Dissolvia-se à bala. Idêntico destroço lavrava noutros pontos. Rapidamente, com um ritmo inflexível, de minuto em minuto, as graduações dos chefes caíam em escalas assustadoras. O $14^{\circ}$ de Infantaria, ao abalar em reforço às linhas do flanco direito, perdera, transcorridos alguns metros, o comandante, major Pereira de Melo. Substituiu-o o capitão Martiniano de Oliveira e, a breve trecho, foi retirado da linha, baleado. O capitão Sousa Campos, que lhe sucedeu, apenas dados alguns passos, caiu morto. O $14^{\circ}$ prosseguiu comandado por um tenente.
A mortandade alastrava-se deste modo por todas as linhas e, como uma agravante, ao fim de duas horas de um combate feito sem a mínima combinação tática, viu-se que as munições se esgotavam. A artilharia, dizimada na eminência em que permanecera valentemente, dera o último tiro, calando o canhoneio. Perdera a metade dos oficiais, e entre estes o capitão fiscal do $5^{\circ}$ Regimento, Nestor Vilar Barreto Coutinho.

Começaram a chegar ao quartel-general reclamos insistintes para que fossem municiados os batalhões.

Fez-se, então, seguir à retaguarda o capitão Costa e Silva, assistente do deputado do Quartel-Mestre-General, a fim de apressar a vinda do comboio. Resolução tardia. Dois ajudantes de ordens imediatamente enviados depois dele volveram de rédeas, percorrido um quilômetro. Não podiam romper as fuzilarias que trancavam a passagem. Cortara-se a retaguarda. E se parassem o tumulto, o estrépito de armas, o alarido confuso e estampidos insistentes, que estrugiam os ares em torno dos lutadores, no alto da Favela, eles perceberiam o tiroteio longínquo do $5^{\circ}$ de Polícia a braços com os jagunços, a duas léguas de distância.

\section{Uma divisão aprisionada}

Toda a primeira coluna estava aprisionada. Por mais estranho que se afigure o caso não havia aos triunfadores um meio de sair da posição que tinham conquistado. Confessa-o o general-em-chefe ${ }^{3}$ :

Atacado o comboio e interdita a passagem de qualquer soldado, como demonstraram os casos precedentes, tive de mandar uma força de cavalaria ao general Cláudio do Amaral Savaget, na intenção de receber socorro de munições, o que ainda uma vez contrariou o meu pensamento porque o piquete não pôde atravessar a linha de fogo do inimigo que tiroteava no flanco direito.

Deste modo, batida no flanco direito, de onde tornara repelido o piquete de cavalaria; batida à retaguarda, que dois auxiliares não conseguiram romper; batida no flanco esquerdo, onde se sacrificara gloriosamente e estacara a $3^{\text {a }}$ Brigada; e batida pela frente onde a artilharia,

\footnotetext{
${ }^{3}$ Ordem do dia 118
} 
dizimada, perdera quase toda a oficialidade e emudecera, a expedição estava completamente suplantada pelo inimigo.

Restava-lhe um recurso sobremaneira problemático e arriscadíssimo: saltar fora daquele vale sinistro da Favela, que era como uma vala comum imensa, a ponta de baionetas e a golpes de espadas.

Fez-se, porém, uma última tentativa. Um emissário seguiu furtivamente, insinuando-se pelas caatingas, em busca da $2^{\mathrm{a}}$ coluna, que estacionara menos de meia légua, ao norte...

\section{Capítulo III}

\section{Coluna Savaget}

A tropa do general Cláudio do Amaral Savaget partira de Aracaju. Fizera alto nas cercanias de Canudos, depois de uma marcha de setenta léguas. Viera pelo interior de Sergipe em brigadas isoladas até Jeremoabo, onde se organizara em 8 de junho, prosseguindo a 16, unida, para o objetivo das operações.

Forte de 2.350 homens, incluídas as guarnições de dois Krupps ligeiros, caminhara passo folgado e firme, para o que contribuíra dispositivo mais bem composto para as circunstâncias.

Aquele general, sem avocar a si, inteira e rígida, uma autoridade, que sob tal forma seria contraproducente, repartira-a, sem deslize da inteireza militar, com os seus três auxiliares imediatos, coronéis Carlos Maria da Silva Teles, Julião Augusto da Serra Martins e Donaciano de Araújo Pantoja, comandantes da $4^{\mathrm{a}}$, $5^{\mathrm{a}}$ e $6^{\mathrm{a}}$ Brigadas. E estes realizaram até às primeiras casas do arraial uma marcha que se destaca das demais.

Não havia instruções prescritas. Não se ideara justapor ao áspero teatro da guerra a esquadria das formaturas, ou a retitude de planos preconcebidos. A campanha, compreenderam-na como a deviam compreender: imprópria a opulências de teorias guerreiras exercitadas através de um formalismo compacto; e girando toda em tática estreita e selvagem, feita de deliberações de momento.

Pela primeira vez os lutadores suportavam-na numa atitude compatível: subdivididos em brigadas autônomas, para se não dispersarem; e móveis bastante para se modelarem à rapidez máxima das manobras ou movimentos que, subtraindo-as a surpresas, as preparassem a aguardar a única coisa que na guerra aventurosa e sem regras lhes era dado esperar o inesperado. As três brigadas, ágeis, elásticas e firmes, abastecidas de comboios parciais, que lhes não travavam os movimentos; feitas para desenvolverem a envergadura à ginástica das guerrilhas e às asperezas da terra, repartindo a massa da divisão, substituíam-lhe a importância do número pela da velocidade e vigor das evoluções aptas a se realizarem nas 
mais circunscritas áreas de combate, sem os entraves dos elefantes de Pirro de uma artilharia imponente e imprestável.

Viera na frente a $4^{\mathrm{a}}$ composta dos $12^{\circ}$ e $31^{\circ}$ Batalhões, comandados pelo tenente-coronel Sucupira de Alencar Araripe e major João Pacheco de Assis.

\section{Carlos Teles}

Dirigia-se o coronel Carlos Teles — a mais inteiriça organização militar do nosso exército nos últimos tempos.

Perfeito espécime desses extraordinários lidadores riograndenses bravos, joviais e fortes - era como eles feito pelo molde de Andrade Neves, um chefe e um soldado: arrojado e refletido, impávido e prudente, misto de arremessos temerários e bravura tranquila; não desadorando o brigar ao lado da praça de pré no mais aceso dos recontros, mas depois de haver planeado friamente a manobra.

A campanha federalista do Sul dera-lhe invejável auréola. A sua figura de campeador - porte dominador e alto, envergadura titânica, olhar desassombrado e leal - culminara-lhe o episódio mais heroico, o cerco de Bagé.

A campanha de Canudos ia ampliar-lhe o renome. gaúchos.

Compreendeu-a como poucos. Tinha a intuição guerreira dos

De posse de sua brigada e, abalando com ela, isolado, para Simão Dias, onde chegou a 4 de maio, modelara-a em pequeno corpo de exército adaptando-a às exigências da luta.

Aligeirou-a; adestrou-a; e como era impossível transmudar a instrução prática dos soldados que vinham de um severo exercício de batalhas nos campos do Rio Grande, procurou, malgrado o antagonismo do terreno, dar-lhe, em parte a mesma celeridade das marchas, o mesmo arranco vertiginoso das cargas. Escolheu, entre as companhias do $31^{\circ}$, sessenta homens, cavaleiros adestrados, decaídos "monarcas das coxilhas" inaptos ao passo tardo dos pelotões de infantaria. E constituiu com eles um esquadrão de lanceiros, entregando-os ao comando de um alferes. Era uma inovação; e parecia um erro. A arma “fria e silenciosa” de Damiroff, feita para os arrancos e choques nas estepes e nos pampas, à primeira vista se impropriava em absoluto àquele solo revolto e recamado de espinheiros.

Entretanto, mais tarde se verificou o alcance da medida.

Os improvisados lanceiros tinham a prática das corridas pulando sobre as "covas de touro" das campinas do Sul.

Vingaram de idêntico modo os barrocais do sertão. Fizeram reconhecimentos preciosos. E mais tarde, quando se reuniram as colunas no ermo da Favela, a lança fez-se-lhes a aguilhada do vaqueiro, no arrebanhar o gado esparso pelas cercanias, único sustento com que contava a tropa combalida.

Esta função dupla patentou-se valiosíssima, sob o primeiro aspecto, logo ao partir a divisão do general Savaget de Jeremoabo para Canudos. Levava esclarecida a marcha.

Dias antes, vinte soldados daquele esquadrão haviam batido a estrada até às cercanias do povoado, e do reconhecimento resultava estar, aquela, franca até a Serra Vermelha onde o terreno se acidenta nos primeiros cerros de Cocorobó.

A coluna em marcha de duas léguas por dia, beirando o Vaza-Barris, passando sucessivamente pelos pequenos sítios de Passagem, Canabrava, Brejinho, Mauari, Canché, Estrada Velha e Serra Vermelha, chegou àquele ponto a 25 de junho certa de encontrar o inimigo.

Pela primeira vez uma tropa expedicionária dos sertões não se deixava surpreender.

\section{Cocorobó}

Cocorobó, nome que caracteriza não uma serra única mas sem número delas, recorda restos de antiquíssimos canyons, vales de erosão ou quebradas, abertos pelo Vaza-Barris em remotas idades, quando incomparavelmente maior efluía talvez de grande lago que cobria a planície rogada de Canudos. A massa de águas, então contida pelos acidentes mais possantes que ondulavam da Favela ao Caipã, nos dois quadrantes de SO e 
NO e deste último espraiando-se pelo de NE, abarreirada pelas serranias de Poço de Cima e Canabrava, efluía para leste em escoadouros estreitos.

\section{Retrospecção geológica}

A sua conformação topográfica instiga esta retrospecção geológica. Com efeito, as serranias cortadas de angusturas, fracionando-se em serrotes de aclives vivos, figuram-se ruínas de uma barragem aluída e rota pelas enchentes. Aprumam-se entre várzeas, feito um recorte nas planuras, e a despeito dos contornos incorretos, permitem que se lhes reviva o facies primitivo. São uma montanha fóssil. Definido pelas mesmas camadas silurianas, que vimos noutros trechos, o núcleo da terra, ali, aflora à medida que a ablação das torrentes lhe remove as formações sedimentárias mais modernas. E nesse exumar-se a serra primitiva ressurge espelhando na ousadia das curvas hipsométricas a potência dos elementos que há longos séculos a combatem. Porque, como na Favela, a caatinga resistente lhe morre no sopé; evita-a; deixa-lhe desnudos os flancos; e estes, já lastrados de blocos, já descendo a prumo, à maneira de muros em cujas junturas ma se apegam orquídeas enfezadas; ou alcantilando-se em fraguedos, repentinos ressaltos que os rasgam em pontas crivando-os até ao alto, onde se agrupam em grimpas serreadas, contrastam com os terrenos achanados em roda, não já na forma, senão na estrutura definidora.

Quem segue de Canudos para Jeremoabo depara, entretanto, com uma passagem única - a brecha profunda por onde se enfia o Vaza-Barris, correndo para o levante. Rompe-a com ele, porque o rio é a única vereda, trilhando-lhe o leito vazio, e, transcorridos alguns metros, acredita haver varado por um postigo estreito. Acaba-se o desfiladeiro. Afastam-se vivamente as rampas abruptas que o formam; arqueando-se e desatando-se por diante, fronteando-se, contrapostas as concavidades numa arqueadura de anfiteatro amplíssimo. Ali dentro, porém, o terreno continua revolto; erguem-se outros cerros mais baixos, centralizando-o; e a primitiva passagem bifurca-se, encaixando-se na direita, em curva, o Vaza-Barris. Estas duas gargantas de larguras variáveis, apertando-se de cerca de vinte metros em dados pontos, progridem, encurvando-se a pouco e pouco, segundo o traçado dos dois galhos exteriores da serra; e, acompanhando-os, aproximam-se convergentes, depois do primitivo afastamento, até se unirem outra vez, formando outra passagem única sobre a estrada de Jeremoabo.
Aos lados de ambas, antes deste cruzamento, em grande percurso, fronteiam os taludes dos cerros centrais com os das duas vertentes laterais, envolventes e maiores, eriçadas de penhascos acumulados a esmo ou agrupando-se em socalcos, repartindo-se em sucessivos patamares à maneira de galerias de um coliseu monstruoso.

O desfiladeiro de Cocorobó é em pálido resumo aquele rasgão da terra, de extremos afunilados, que se subdividem de um e outro lado na forquilha de dois outros porventura ainda menos praticáveis. A estrada duplica-se na falsa encruzilhada de dois desvios que o Vaza-Barris percorre por igual nas enchentes, ilhando os cômoros centrais - até sair, unidos os dois braços, numa várzea desimpedida e vasta que o caminho de Jeremoabo corta pelo meio, estirando-se em cheio para leste.

De sorte que quem a trilha em sentido oposto, vindo daquela vila para o ocidente, incide de idêntica maneira na bifurcação que a divide. Atravessa-a, metendo-se por uma das veredas, à direita ou à esquerda, até chegar à outra saída única. Transpõe-na. Mas livre da garganta multívia não encontra uma várzea complanada como a da outra banda. O solo, ainda que em menor escala, continua revolto. O Vaza-Barris, contorcido em meandros, alonga-se, entalado, entre cerros sucessivos. A estrada que o fraldeia, ou acompanha-lhe o leito, perturba-se em atalhos, ondulante, tornejando sem número de encostas, derivando em aladeirados; e vai até ao vale de um ribeirão efêmero, ao qual deu o nome um dos cabecilhas sertanejos que ali tinha a vivenda, Macambira.

Segue dali, perlongando qualquer das bordas do rio, até Canudos, menos de duas léguas na frente.

\section{Diante das trincheiras}

A vanguarda da força marchando neste sentido fez alto uns quinhentos metros antes daquela barreira, no dia 25 de junho, pouco antes do meio-dia.

O esquadrão de lanceiros descobrira o inimigo. Abeirara-se, galopando, dos entrincheiramentos grosseiros e vira-os, de relance. Recebido a tiro, volvera a toda a rédea, perdendo duas praças feridas, para junto da $5^{\text {a }}$ Brigada na testa da coluna, que desenvolveu imediatamente em 
atiradores um dos seus batalhões, o $40^{\circ}$, do major Nonato de Seixas, enquanto os dois outros, o $34^{\circ}$ e o $35^{\circ}$, se dispunham de reforço. O general Savaget, prevenido do encontro, adiantara-se acompanhando a $4^{a}$ Brigada. Estacou a quatrocentos metros da vanguarda, a fim de aguardar a $6^{a}$ Divisão de Artilharia e os comboios marchando ainda cerca de três quilômetros à retaguarda. Enquanto isto passava, os corpos avançados, mais de oitocentos homens ao mando do coronel Serra Martins, iniciavam o ataque num tiroteio nutrido, em que os fogos irregulares da linha de atiradores se intermeavam das descargas rolantes dos pelotões que a reforçavam mais de perto, revidando vigorosamente aos tiros dos antagonistas. Estes sustentaram o choque com valor.

Audaciosos e tenazes, diz a parte do combate do comando-geral, qualidades essas que eram ao que parece reforçadas pelas excelentes posições que ocupavam, as quais dominavam a planície em toda a extensão e grande trecho da estrada, não arredaram pé e, ao contrário, aceitaram e sustentaram com firmeza e energia o ataque, rompendo renhida fuzilaria sobre os nossos, tanto que começamos a ter algumas baixas por mortes e ferimentos.

Era, como se vê, a reprodução justalinear dos episódios do Cambaio e da Favela.

Os sertanejos reviviam em cenário idêntico todas as peripécias do dramalhão sinistro e monótono de que eram protagonistas invisíveis. Um maior tirocínio na guerra não lhes variara o sistema, certo porque este, pela própria excelência, não comportava corretivos ou aditamentos. Atiravam, a seguro, do alto daqueles parapeitos desmantelados, sobre a força, inteiramente em alvo na planura descoberta e rasa embaixo. E os seus projetis começaram a rarear-lhe as fileiras mais próximas, derrubando os atiradores, caindo, adiante, entre os corpos que os apoiavam, e irradiando para mais longe em trajetórias altas, sulcando as últimas seções da retaguarda; expandindo-se, dominantes, sobre a expedição inteira.

Não se adensavam, contudo, em descargas por demais cerradas. A justeza substituía-lhe a quantidade. Percebia-se que os atiravam combatentes avaros no contar, um a um, os cartuchos, timbrando em não perderem um único, firmando-os em pontarias cuidadosas. De sorte que, no fim de algum tempo, o tiroteio calculado, ante o qual estrondavam terrivelmente oitocentas Mannlichers, começou de se tornar funestíssimo.
A $5^{a}$ Brigada foi admirável de disciplina, afrontando-o por duas horas, na posição em que estacara, à margem do Vaza-Barris, abrigando-se entre os ralos arbustos que a revestem. Não adiantara, em todo esse tempo, um passo. A um simples lance de vista, punham-se de manifesto os riscos de uma investida visando as duas angusturas, que se lhe abriam fronteiras, e imporiam, durante o assalto, um desfilar em seções diminutas, capaz de the anular o vigor precisamente na fase mais decisiva. Por outro lado não havia evitá-las, contornando-as. À direita e à esquerda se sucediam montes crespos de contrafortes, e procurar entre eles um desvio qualquer pressupunha uma marcha de flanco, talvez dilatada, sob a vigilância do inimigo, o que seria problematizar ainda mais qualquer sucesso vantajoso.

O general Savaget aquilatou com firmeza a conjuntura gravíssima.

Em que pese aos seus oito batalhões, magnificamente armados, a luta era desigual. Depois de uma marcha segura, esclarecida por explorações eficazes que predeterminaram o dia e a sede do recontro, tinha-os, ali, havia duas horas, manietados, sacrificados e inúteis - sob o espingardeamento impune de um ajuntamento de matutos.

$\mathrm{O}$ transe requeria combinações concretas, de momento; improvisos de estratégia, repentinos e de pronto executados. Nas aperturas do dilema acima exposto, porém, e diante do contraste das posições adversas, nenhum ocorria capaz de o resolver. O alvitre do momento resumia-se no reagir, arrastando tudo, ao bárbaro fuzilamento. Foi reforçada a vanguarda. Chegara a divisão de artilharia e um dos Krupps destacou-se logo para junto das linhas avançadas.

Bombardeou-se a montanha. Arrojadas de perto as granadas e lanternetas, batendo-lhe em cheio os flancos ou ricochetando, confundiam nos ares as balas e estilhas de ferro com o lastro aspérrimo das encostas rijamente varridas; e, arrebentando entre fraguedos, deslocando-os, derrubando-os, fazendo-os rolar com estrépito pelos pendores abaixo, como um súbito derruir de lanços de muralhas, pareciam desmascarar inteiramente as posições contrárias. Mas foram contraproducentes. Estimularam réplica violentíssima, estupenda, inexplicável, expluindo maior e mais viva dentre o desabamento das trincheiras. Os atiradores suportavam-na a custo. Rareavam. Os dois batalhões de reforço, francamente engajados na ação, sacrificavam-se inutilmente tendo, 
crescente, o número de baixas. O resto da expedição, estirada em colunas numa linha de dois quilômetros para a retaguarda, permanecia imóvel.

\section{Era quase um revés.}

No fim de três horas de fogo os atacantes não tinham adquirido um palmo de terreno. A quinhentos metros dos adversários, não tinham milhares de vistas fixas nas vertentes despidas - lobrigado um único sequer. Não lhes avaliavam o número. Os cerros mais altos, bojando em esporões sobre a várzea, figuravam-se desertos. Batia-os de chapa o sol ofuscante e ardente; viam-se-lhes os mínimos acidentes da estrutura; podiam contar-se-lhes um a um os grandes blocos, que por ali se espalham, a esmo, mal equilibrados em bases estreitas ao modo de loggans oscilantes e prestes a caírem uns, outros acumulados em acervos imponentes; e distinguiam-se, intermeando-os, em touceiras, ou encimando-os, esparsas, as bromélias resistentes, caroás e macambiras de espatas lustrosas, retilíneas e longas, rebrilhando à luz como espadas; viam se, mais raros, cactos esguios e desolados; mais longe, um tumultuar de cimos, do mesmo modo desertos.

E daquele desolamento, daquela solidão absoluta e impressionadora, irrompia, abalando as encostas, uma "fuzilaria cerrada e ininterrupta como se ali estivesse uma divisão inteira de infantaria!”1.

\section{Carga de baionetas excepcional}

Os jagunços eram duzentos ou eram dois mil. Nunca se lhes soube, ao certo, o número. Na frente dos expedicionários o enigmático da campanha se antolhava mais uma vez, destinando-se a ficar para sempre indecifrável. Tolhendo-se-lhes deste modo o passo, só restavam decisões extremas: ou recuarem lentamente, lutando, até se subtraírem ao alcance das balas; ou contornarem o trecho inabordável, buscando um atalho mais acessível, em movimento envolvente aventuroso, de flanco, o que redundaria em desbarate inevitável; ou arremeterem em cheio com os outeiros, conquistando-os. O último alvitre era o mais heroico e o mais simples. Sugeriu-o o coronel Carlos Teles. O general Savaget adotou-o. Conforme confessa em documento oficial onde define, com lastimável

${ }^{1}$ Ordem do dia do general Savaget. desquerer, o adversário temível que o fizera parar, não podia admitir "que duas ou três centenas de bandidos sustivessem a marcha da segunda coluna por tanto tempo”. E, como empenhara na ação pouco mais de um terço das tropas, esta circunstância salvou-o, tornando factível uma manobra arrojada, certo irrealizável se todos os batalhões, num arremesso único se tivessem embaralhado desde o começo às duas entradas do desfiladeiro.

Planeou-a:

A $5^{\text {a }}$ Brigada, que se mantinha desde o princípio nas suas posições por entre as caatingas, devia carregar pelo flanco esquerdo e pelo leito do rio, a fim de desalojar o inimigo dos cerros centrais e outeiros, que ficam desse lado, e a $4^{\text {a }}$ pelo flanco direito devendo, antes, desenvolver-se em linha, ao sair da estrada para a várzea.

O esquadrão de lanceiros, entre ambas, carregaria pelo centro. A $6^{\text {a }}$ Brigada não compartiria o combate, permanecendo à retaguarda em reforço, e garantindo os comboios.

Assim os cinco batalhões destinados à investida se dispunham na ordem perpendicular reforçada numa das alas, a da esquerda, onde os corpos avançados do coronel Serra Martins formavam em colunas sucessivas, enquanto, quatrocentos metros atrás e para a direita, se desdobrava, em linha, a Brigada Teles, tendo no flanco esquerdo o esquadrão de lanceiros.

O conjunto da formatura projetava-se na superfície do nível da várzea com a forma exata de um desmedido martelo.

E a carga, que logo depois se executou - episódio culminante da refrega - semelhou, de fato, uma percussão, uma pancada única de 1.600 baionetas de encontro a uma montanha.

Os assaltantes avançaram todos a um tempo: os pelotões da frente embatendo com os morros e enfiando pela bocaina da passagem esquerda, enquanto a $4^{\text {a }}$ Brigada, a marche-marche, de armas suspensas e sem atirar, vencia velozmente a distância que a separava do inimigo. Tomara-lhe a frente o coronel Carlos Teles. Este oficial notável — recordando Osório na postura e Turenne no arrojo cavalheiresco - sem desembainhar a espada, hábito que conservou em toda a campanha, atravessou com a sua gente todo o trecho do campo varejado de balas. 
No sopé da serrania, à esquerda, se abria o desfiladeiro da direita, por onde se meteu atrevidamente, em disparada, o esquadrão de cavalaria. A $4^{\text {a }}$ Brigada, porém, evitou-o. Investiu com as encostas. Os jagunços não haviam contado com este movimento temerário, visando diretamente, a despeito dos obstáculos de uma ascensão difícil, as posições que ocupavam. Pela primeira vez se deixaram surpreender por inesperada combinação tática, que os desnorteava, obrigando-os a deslocarem para outros pontos os lutadores de antemão destinados a trancarem as duas passagens estreitas, por onde acreditavam investiria toda a tropa. A $4^{\mathrm{a}}$ Brigada, realizando a mais original das cargas de baionetas, por uma ladeira íngreme e crespa de tropeços acima, ia decidir do pleito.

Foi um lance admirável. A princípio avançou corretíssima. Uma linha luminosa de centenares de metros se estirou, fulgurando. Ondulou à base dos cerros. Abarcou-os; e começou a subir. Depois inflectiu em vários pontos; envesgou, torcida, pelas encostas; e, a pouco e pouco, desarticulada, fragmentou-se. Os sertanejos, entocaiados a cavaleiro, golpeavam-na; partiam-na, por sua vez, as anfractuosidades do solo. A linha do assalto, rota em todos os pontos, subdividida em pelotões estonteadamente avançando, espelhou-se, revolta, nos pendores da serra...

O coronel Teles, guiando-a pelo flanco direito do $31^{\circ}$ de Infantaria, perdeu nessa ocasião o cavalo que montava, atravessado por uma bala junto à espenda da sela. Substituiu-o. Reuniu as frações dispersas de combatentes, em que já se misturavam soldados dos seus dois corpos. Animou-os. Arrojou-os valentemente sobre as trincheiras mais próximas. Encontraramnas vazias, tendo cada uma, ao fundo, dezenas de cartuchos detonados e ainda mornos. Consoante à tática costumeira, os jagunços deslizavam-lhes adiante, recuando, negaceando, apoiando-se em todos os acidentes, deslocando a área do combate, impondo todas as fadigas de uma perseguição improfícua. A breve trecho, porém, dominadas as primeiras posições, viu-se, sobre as vertentes que apertam o desfiladeiro naquele ponto, a $4^{\mathrm{a}}$ Brigada, escalando-as. Dali tombavam os mortos e os feridos, alguns até ao fundo da garganta, embaixo, por onde tinham entrado os sessenta homens do esquadrão de lanceiros e a divisão de artilharia, quebrando-se, ambos, de encontro a forte trincheira posta de uma e outra margem do rio, na bifurcação das duas bocainas, feito uma represa. Nas vertentes da esquerda, a $5^{\mathrm{a}}$ Brigada, perdida igualmente a formatura primitiva, lutava do mesmo modo tumultuário.

A ação tornou-se formidável. Cinco batalhões debatiam-se entre morros, sem vantagem sensível, depois de quatro horas de luta. Aumentara grandemente o número de feridos repulsados do alvoroto das cargas, titubeantes, caindo ou arrimando-se às espingardas, errantes pelas faldas, descendo-as, entre os mortos por ali jacentes, a esmo.

Embaixo, no vale estreito, viam-se, sem dono, disparados em todos os sentidos, relinchando de pavor, os cavalos do esquadrão de lanceiros, que arrebentara arrojadamente sobre a forte trincheira do rio..

\section{A travessia}

Nesta enorme confusão alguns pelotões do $31^{\circ}$ de Infantaria galgaram, afinal, num ímpeto incomparável de valor, as trincheiras mais altas da vertente da direita. E cortadas, deste modo, as guarnições das que se sucediam a espaços pela linha de cumeadas, abandonaram-nas inesperadamente. Não era o recuo temeroso habitual; era a fuga. Os adversários foram ali, vistos de relance, pela primeira vez: dispersos pelos altos, correndo e sobraçando as armas, rolando e resvalando pelos declives, desaparecendo. Os soldados encalçaram-nos; e, revigorada logo em todos os pontos, a investida, num movimento único para frente, propagou-se até às alas da extrema esquerda. Era a vitória. Minutos depois as duas brigadas, num imenso alvoroto de batalhões a marche-marche, adensavam-se, confundidas, na última e única passagem do desfiladeiro.

Os jagunços em desordem, contudo, depois do primeiro arranco da fuga, volveram ainda ao mesmo resistir inexplicável. Abandonando as posições e franqueando a travessia perigosa, recebiam, de longe, os triunfadores, a tiros longamente espaçados.

O general Savaget foi atingido e desmontado juntamente com um ajudante de ordens e parte do piquete quando, à retaguarda da coluna, penetrava a garganta da direita e já se ouviam, ao longe, as aclamações triunfais dos combatentes da vanguarda. Como sempre, os sertanejos tornavam incompleto o sucesso, ressurgindo inexplicavelmente dentre os estragos de um combate perdido. Batidos, não se deixaram esmagar. 
Desalojados de todos os pontos, abroquelavam-se noutros, vencidos e ameaçadores, fugindo e trucidando, como os partas. Haviam, entretanto, sofrido sério revés, e a denominação, que ulteriormente deram de "batalhão talentoso” à coluna que lho infligira, por si só o denota. Porque o combate de Cocorobó, a princípio vacilante, indeciso numa dilação de três horas de tiroteios ineficazes, e ultimando-se por uma carga de baionetas fulminante, foi, de fato, um raro golpe de audácia apenas justificável, senão pelo dispositivo das tropas que o vibraram, pela sua natureza especial. Predominava nas fileiras o soldado rio-grandense. E o gaúcho destemeroso, se é frágil ao suportar as lentas provações da guerra, não tem par no se despenhar em súbitos lances temerários.

A infantaria do Sul é uma arma de choque. Podem suplantá-la outras tropas, na precisão e na disciplina de fogo, ou no jogo complexo das manobras. Mas nos encontros à arma branca aqueles centauros apeados arremetem com os contrários, como se copiassem a carreira dos ginetes ensofregados das pampas. E a ocasião sorrira-lhes para a empresa estupenda levada a cabo com brilho inexcedível.

À tarde, acampadas as forças além da passagem, verificaram-se as perdas sofridas: 178 homens fora de combate, dos quais 27 mortos, em que se incluíam dois oficiais mortos e dez feridos.

A $6^{a}$ Brigada, que não tomara parte na ação, foi encarregada do enterramento dos últimos, e acampou à retaguarda das duas outras, que ocupavam extensa rechã sobranceira à estrada.

\section{Macambira}

Depois disto a marcha se fez num combate contínuo. Foi lenta. Todo o dia 26 se despendeu em breve travessia até à confluência do Macambira, poucos quilômetros além de Cocorobó.

O general Savaget comunicou, então, às tropas que no dia subsequente, 27, segundo determinara o comando-em-chefe, deviam estar na orla de Canudos, de onde, feita a convergência das seis brigadas, iriam dar, reunidas, sobre o arraial. Este devia estar mui perto. Viam-se já, esparsas, pelo teso dos outeiros, as choupanas colmadas, de disposição especial anteriormente descrita: surgindo dentre trincheiras ou fossos mascarados de touceiras de bromélias, feitas a um tempo lares e redutos.

A $2^{\mathrm{a}}$ coluna ao avançar naquele dia - nos últimos passos da jornada —, tendo à vanguarda a $6^{\mathrm{a}}$ Brigada, com o $33^{\circ}$ de Infantaria à frente, penetrava os subúrbios da tremenda cidadela. E mal percorridos dois quilômetros, quando ainda restava no acampamento o grosso dos combatentes, empenharam-se, batidos de todos os flancos, em combate sério, os batalhões do coronel Pantoja.

\section{Nova carga de baionetas}

Foi, de pronto, adotado o expediente que na véspera tivera tão seguras efeitos. Os Batalhões $26^{\circ}, 33^{\circ}$ e $39^{\circ}$ desdobrando-se em linha, calaram as baionetas e lançaram-se impetuosamente pelos recostos das colinas. Galgaram-nas em tropel. E depararam em torno, por todos os lados, outras, sem número de outras, apontoando o terreno rugado, desatado por muitos quilômetros em roda...

De todas elas, irrompendo dos casebres que as encimavam, convergiam descargas. O campo de combate, agora amplíssimo, estava adrede moderado às ardilezas do adversário: vencido qualquer um dos cômoros, viam-se centenares de outros a subir. Descida uma baixada, caíase num dédalo de sangas. A investida seria um colear fatigante pelas linhas flexuosas dos declives. Poucos quilômetros adiante se lobrigava, indistinto, sob o aspecto tristonho de enorme cata abandonada, Canudos...

\section{Fuzilaria}

\section{A peleja travara-se à ilharga e foi renhidíssima.}

A breve trecho os três batalhões da vanguarda viram-se impotentes para a suportarem: das choupanas atestadas de lutadores, de todas as trincheiras dispersas pelos cerros, partiam, convergentes, fuzilarias seguras, dizimando-os.

Uma companhia do $39^{\circ}$, logo no começo da ação, fora literalmente esmagada batendo um daqueles redutos selvagens. Vingara improvisamente o outeiro e no topo estacara à borda de um fosso largo, ao tempo que do casebre por este envolvido partiam dentre as rachas das paredes, batendo-a 
em cheio e à queima-roupa, descargas furiosas. Perdeu logo o comandante, perdendo imediatamente depois, sucessivamente, dois subalternos que o substituíam, conquistando afinal a posição, depois de grandemente rarefeita, às ordens de um sargento.

Diante desta resistência imprevista aquela brigada única, inapta para abranger a área extensíssima do combate, foi reforçada pelas duas outras. Sucessivamente os Batalhões $12^{\circ}, 31^{\circ}, 35^{\circ}$ e $40^{\circ}$, enviados em reforço, avançaram. Eram mais de mil baionetas, quase toda a coluna, empenhadas no conflito. Os jagunços então recuaram; e recuando lentamente, de colina em colina, desalojados de um ponto para surgirem em outro, obrigando os antagonistas a um contínuo descer e subir de ladeiras, parecia desejarem arrebatá-los até ao arraial, exaustos e torturados de tiroteios. Volviam à tática invariável. O campo do combate começou a fugir debaixo dos pés aos assaltantes. As cargas de baionetas não tiveram então o brilho das de Cocorobó. Amolentava-as a retratilidade daquele recuo. Arrojados contra os cerros, os pelotões alcançavam os altos sem toparem mais um só adversário. Batidos logo na posição interjacente, enfiada pelos tiros partidos das eminências interpostas, desciam-na, em grupos, precipitadamente, buscando os ângulos mortos das baixadas - para reproduzirem, mais longe, a mesma escalada exaustiva e a mesma exposição perigosa às balas.

Começaram a perder, além de grande número de praças, oficiais altamente graduados. O comandante do $12^{\circ}$, tenente-coronel Tristão Sucupira, tombara moribundo quando seguia em esforço à vanguarda. $\mathrm{O}$ do 33, tenente-coronel Virgílio Napoleão Ramos, fora também retirado, ferido, da ação, assim como o capitão Joaquim de Aguiar, fiscal do mesmo corpo. E outros e muitos outros se sacrificaram nesse mortífero combate de Macambira, nome do sítio adjacente, porque, impropriando o terreno quaisquer combinações táticas capazes de balancearem as negaças vertiginosas do inimigo, todas as garantias de sucesso se resumiam na coragem pessoal. Alguns oficiais, como o capitão ajudante do $32^{\circ}$, com mais de um ferimento sério, se obstinavam no recontro, surdos à intimativa dos próprios comandantes determinando-lhes a retirada das linhas de fogo. Estas desatavam-se por três quilômetros. - Deflagravam pelos outeiros, crepitavam, ressoantes, nas baixadas, e rolavam para Canudos...
A noite fê-las parar. A expedição estava a um quarto de légua do arraial. Viam-se, fronteiras e altas, longe, branqueando no empardecer do crepúsculo, as torres da igreja nova...

Estava enfim atingido o termo da marcha por Jeremoabo. A segunda coluna, porém, pagara-o duramente: tivera neste dia 148 homens fora de combate, entre os quais quarenta mortos, seis oficiais mortos e oito feridos. Somadas às perdas anteriores perfaziam 327 baixas, que tanto custara a travessia de menos de três léguas, de Cocorobó até àquele lugar.

Mas tudo delatava sucesso compensador. Realizara-se pontualmente o itinerário preestabelecido: minutos depois de acampadas, as tropas do general Savaget ouviram, no flanco esquerdo, estrugindo o silêncio das noites sertanejas e reboando longamente pelos contrafortes da Favela o canhoneio àquela hora aberto pela vanguarda da $1^{\mathrm{a}}$ coluna.

\section{Bombardeio}

No dia 28, tendo avançado cedo e tomado posição em pequeno platô, distante dois quilômetros do arraial, começou por sua vez a bombardeá-lo, enquanto os dois batalhões da Brigada Carlos Teles se avantajavam mais para a frente ainda, em reconhecimento rápido. Um piquete de cavalaria, dirigido por um valente, destinado a uma morte heroica, o alferes Wanderley, explorou o terreno pelo flanco esquerdo, até à Favela, onde àquela hora — oito da manhã — recrudescera, intenso, o canhoneio.

A dois passos do comando-em-chefe, a segunda coluna estava pronta para o assalto. Chegara até ali ultimando uma travessia de setenta léguas com um combate de três dias

Impusera-se ao inimigo; afeiçoara-se ao caráter excepcional da luta; e o movimento irreprimível da carga que iniciara em Cocorobó e prolongara ininterruptamente até àquele ponto poderia arrebatá-la, triunfante, ao centro de Canudos, em plena praça das igrejas. Vinha, a despeito das perdas que tivera, esperançosa e robusta. A ordem do dia de 26 , em que o seu comandante lhe comunicou o próximo assalto, em companhia dos companheiros da $1^{\text {a }}$ coluna, é expressiva. 


\section{Trabubu}

Foi dada em Trabubu, na travessia dos desfiladeiros, e diz muito no próprio laconismo. A nova, entusiasticamente recebida, deriva de poucas palavras, corteses e despretensiosas:

Acampamento no campo de batalha de Cocorobó, 26 de junho de 1897.

Meus camaradas. Acabo de receber do Sr. general comandante-emchefe um telegrama comunicando-me que amanhã nos abraçaremos em Canudos. Não podemos, portanto, faltar ao honroso convite, que é para nós motivo de justo orgulho e de completa alegria.

A concentração almejada, através de um assalto convergente, far-seia, porém, fora do centro da campanha.

\section{Emissário inesperado}

Com surpresa geral dos combatentes da $2^{\mathrm{a}}$ coluna, que - olhos fitos na Favela - esperavam ver, descendo as vertentes do norte, os batalhões da $1^{\mathrm{a}}$, apareceu no acampamento um sertanejo notificando-lhes, por ordem do comandante-em-chefe, as aperturas em que se achava aquela, exigindo imediato socorro. A nova era inverossímil, e pareceu, nos primeiros momentos, uma traça do adversário. O homem ficou retido até que novo emissário a confirmasse. Este, um alferes honorário, adido à comissão de engenharia, não se fez esperar muito. $\mathrm{O}$ general-em-chefe apelava instantemente para o concurso da outra coluna. Ante o novo reclamo, e informações que o esclareciam, o general Savaget, que a princípio imaginara enviar apenas uma brigada levando munições, ficando as demais sustentando a posição conquistada, seguiu, inflectindo para a esquerda, com toda a sua gente. Chegou, seriam onze horas, ao alto da Favela, a tempo de libertar a tropa assediada.

\section{Destrói-se um plano de campanha}

Preposterara-se, porém, todo o plano de campanha e do mesmo passo se anulara o esforço despendido nas marchas pelo Rosário e Jeremoabo.
Reunidas as colunas, tornou-se possível destacar um contingente para reaver o comboio retido à retaguarda. Foi cometido o encargo ao coronel Serra Martins que prontamente refluiu à reçaga da expedição intercisa, levando a $5^{\text {a }}$ Brigada - num oscilar perigoso entre dois combates — até às Umburanas, onde chegou ainda a tempo de impedir o desbarate do $5^{\circ}$ de Polícia e salvar parte dos volumes de 180 cargueiros que, dispersos pelos caminhos, tinham sido grandemente danificados pelos jagunços.

Este movimento feliz, porém, de pouco atenuou as condições estreitas da tropa. Mal paliou o transe. Firmou-se logo um regime desesperador de contrariedades de toda a sorte. 


\section{Capítulo IV}

\section{Vitória singular}

A ordem do dia relativa ao feito de 28 de junho caracteriza-o "uma página tarjada de horrores, mas perfumada de glória”.

\section{Mas fora franco o revés.}

Não iludiu a História o fanfarrear do vencido. O exército vitorioso, segundo o brilhante eufemismo das partes oficiais armadas a velarem aquele insucesso, apresentava na noite daquele dia o caráter perfeito de uma aglomeração de foragidos. Triunfadores que não podiam ensaiar um passo fora da posição conquistada, tinham caído num período crítico da guerra: perdidos os alentos em recontros estéreis, ou duvidosas vitórias, que valiam derrotas, apoucando-lhes do mesmo passo as forças e o ânimo, sentiam-se dissociados e de algum modo unidos apenas pela pressão externa do próprio adversário que haviam julgado sopear facilmente. O heroísmo era-lhes, agora, obrigatório. A coragem, a bravura retransida de sobressaltos, um compromisso sério com o terror. Circulavam-nos os mais originais dos vencidos: impiedosos, enterreirando-os em todos os pontos no círculo de um assédio indefinido e transmudando-se em fiscal incorruptível, trancando todas as abertas à deserção. De sorte que, ainda quando não carecessem de valor, os nossos soldados não tinham como se subtrair à emergência gravíssima em que se equiparavam heróis e pusilânimes.

\section{O medo}

A história militar, de urdidura tão dramática a recamar-se por vezes das mais singulares antíteses, está cheia das grandes glorificações do medo. A ânsia perseguidora do persa fez a resignação heroica dos "Dez mil”; a fúria brutal dos cossacos imortalizou o Marechal Ney...

Íamos enxertar-lhe, idêntico, senão na amplitude do quadro na paridade do contraste, um capítulo emocionante - porque a tenacidade feroz do jagunço transfigurou os batalhões combalidos do general Artur Oscar. E eles ali quedaram unidos, porque os enlaçava a cintura de pedra das trincheiras, impertérritos, porque lhes era impossível o recuo; forçadamente heroicos, encurralados, cosidos à bala numa nesga de chão...

\section{Baixas}

Nada revelava mesmo breves linhas de acampamento no acervo das brigadas. Não se armaram barracas que roubariam espaço demais na área de si estreita. Não se ordenaram ou se dividiram as unidades combatentes. A tropa -5 mil soldados, mais de novecentos feridos e mortos, mil e tantos animais de montada e tração, centenares de cargueiros - sem flancos, sem retaguarda, sem vanguarda, desorganizara-se por completo. A primeira coluna tivera naquele dia 524 homens fora de combate que, com 75 da véspera, somavam 599 baixas. A segunda ligara-se-lhe desfalcada de 327 combatentes. Ao todo 926 vítimas. Fora sem número de estropiados exauridos das marchas, sem número de famintos e grande maioria de pusilânimes sob a emoção dos morticínios recentes e vendo por ali estirados, insepultos, companheiros pela manhã ainda entusiastas e vigorosos:

- Thompson Flores, vitimado no comando fatídico do $7^{\circ}$ de Infantaria; Tristão de Alencar Sucupira, que chegara agonizante com a $2^{\mathrm{a}}$ coluna; Nestor Vilar, capitão fiscal do $2^{\circ}$ Regimento, que caíra com mais de dois terços da oficialidade de artilharia; Gutierrez, oficial honorário, um artista que fora até lá atraído pela estética sombria das batalhas; Sousa Campos, que comandara por um minuto o $14^{\circ} \ldots$ e outros de todas as graduações, lançados por toda a parte.

Um rasgão de enxurros se escancelava longo, longitudinalmente, afundando o sulco da garganta. E dentro dele mais de oitocentos baleados punham no tumulto a nota lancinante de sofrimentos irreparáveis. Aquela prega do solo, onde se improvisara um hospital de sangue, era a imagem material do golpe que sulcara a expedição, abrindo-a de meio a meio. Considerando-a entibiavam-se os mais fortes. Porque, afinal, nada compensava tais perdas ou explicava semelhante desfecho a planos de campanha tão maduramente arquitetados. Triunfantes e unidas, as duas colunas imobilizaram-se impotentes ante a realidade. Apagavam-se as linhas de ordens do dia retumbantes. Estavam no centro das operações - e não podiam dar um passo à frente ou, o que era pior, não podiam dar um 
passo à retaguarda. Haviam esparzido profusamente pelos ares mais de um milhão de balas; haviam rechaçado o adversário em todos os encontros e sentiam-no porventura mais ameaçador em roda, prendendo-os, cortandolhes o passo para o recuo, depois de o haverem tolhido para a investida.

Realmente tudo delatava um assédio completo. A $5^{\mathrm{a}}$ Brigada no movimento que fizera à retaguarda perdera quatorze homens. $\mathrm{O} 5^{\circ}$ de Polícia, 45. Foram e voltaram num tirotear incessante pelos caminhos entrincheirados.

A expedição, em pleno território rebelde, insulara-se sem a mais ligeira linha estratégica vinculando-a à base de operações em Monte Santo, a não ser que se considerasse tal a perigosa vereda do Rosário, repleta de emboscadas. E como o comboio reconquistado chegara reduzidíssimo, ficando mais de metade das cargas em poder dos sertanejos, ou inutilizada, a tropa perdera munições de inestimável valor na emergência, e ao mesmo tempo os aparelhara com cerca de 450.000 cartuchos, o bastante para prolongarem indefinidamente a resistência. Municiara-os. Completara o destino singular da expedição anterior que lhes dera espingardas. Estas estrondavam agora, a cavaleiro do acampamento. Os vencidos restituíam daquele modo as balas, estadeando provocações ferozes, aos vitoriosos tontos, que não lhes replicavam.

A noite descera sem que se atreguasse a luta; sem o mais curto armistício, permitindo que se corrigissem as fileiras. Um luar fulgurante desvendava-as às pontarias dos jagunços; e estes, batendo-as calculadamente em tiros longamente pausados, revelavam-lhes a vigilância temerosa, em torno.

Um ou outro soldado, indisciplinadamente, revidava, disparando à toa, a arma, para os ares. Os demais, sucumbidos de fadigas, caídos sobre os fardos por ali esparsos a esmo, estirados sobre o chão duro, quedavam-se inúteis, abraçando as espingardas...

\section{Começo de uma batalha crônica}

A noite de 28 de junho iniciara uma batalha crônica. alarma.

Daquela data ao termo da campanha a tropa iria viver em permanente

Começou desde logo um regime deplorável de torturas. Ao amanhecer de 29 verificaram-se insuficientes as munições de boca, para a ração completa das praças da $1^{a}$ coluna, já abatidas por uma semana de alimentação reduzida.

A $2^{a}$, embora mais bem avitualhada, não tinha por sua vez garantido o sustento por três dias, depois de o repartir com a outra. De sorte que logo no começo desta fase excepcional da luta se lançou mão dos últimos recursos, sendo naquele dia abatidos os bois mansos, que até lá tinham conduzido o pesado canhão 32. Ao mesmo tempo antolhava-se uma tarefa penosíssima: fazer daquele acervo de homens e bagagens um exército; ordenar os batalhões dissolvidos; reconstituir as brigadas; curar centenares de feridos; enterrar os mortos e desatravancar a área reduzida dos fardos e cargueiros, postos por toda a banda. Estes trabalhos indispensáveis realizavam-se, porém, sem método, atumultuadamente, sem a diretriz de uma vontade firme. A colaboração justificável dos comandantes de corpos, dos próprios subalternos, surgia espontânea, de todos os lados, no sugerir sem número de medidas urgentes. De modo que, a breve trecho, toda aquela gente, movendo-se às encontroadas, em todos os sentidos; improvisando trincheiras; agrupando-se ao acaso em simulacros de formatura; arrastando fardos e cadáveres; retirando os muares, cujas patas entaloadas eram ameaça permanente aos feridos que lhes rastejavam aos pés, não teve esforços convergentes e úteis.

\section{Não a dominava, todavia, inteiramente, a desesperança.}

Volvera-lhe com o amanhecer o valor; e, a despeito de tantos casos expressivos, não avaliara ainda bem a pervicácia feroz dos sertanejos. De sorte que nos espíritos ressurgiu o pensamento consolador de próximo desenlace, ante um bombardeio vigoroso que propiciavam as vantajosas posições da artilharia, emparcada a cavaleiro do arraial. Punha-se de manifesto que um vilarejo aberto do sertão não suportasse por muitas horas as balas mergulhantes de dezenove canhões modernos. 


\section{Canhoneio. Réplica dos jagunços}

Mas o primeiro tiro partiu e bateu em Canudos como um calhau numa colmeia. $\mathrm{O}$ acampamento até àquele momento em relativa calma foi, como na véspera, improvisamente varrido de descargas; e, como na véspera, os combatentes compreenderam quase impossível a réplica em tiros divergentes, dispartindo pelo círculo amplíssimo do ataque. Além disto, encafurnados numa dobra de morro, atirando por elevação e sem alvo, as nossas descargas sobre inócuas implicavam estéril malbaratar das munições escassas. Por outro lado, o efeito do canhoneio se patenteou francamente nulo. As granadas, explodindo dentro das casas, perfuravamlhes as paredes e os tetos e como que se amorteciam entre os frágeis anteparos de argila - estourando sem ampliarem o raio dos estragos, caindo muitas vezes intactas sem arrebentarem as espoletas. Por isso o alvo predileto foi, mais uma vez, a igreja nova, bojando no casario baixo, como um baluarte imponente. Ali se alinhavam os jagunços - por detrás das cimalhas das paredes mestras, engrimpados nas torres ou mais abaixo nas janelas abertas em ogivas, ou ao rés-do-chão sobre o embasamento cortado de respiradouros, estreitos à semelhança de troneiras.

Conteirara-se, visando-a, o Whitworth 32, que viera adrede para lhe derrubar os muros. Rugiu, porém, neste dia, sobre ela sem a atingir: as balas passavam-lhe, silvando, sobre a cumeeira. Perdiam-se nos casebres unidos. Uma única tombou sobre o adro, escaliçando a fachada. As demais se perderam. Essa péssima estreia do colosso proveio, principalmente, do açodamento com que o açulavam.

Era uma nevrose doida. A grande peça - o maior cão de fila daquela monteria - fez-se monstruoso fetiche desafiando o despertar de velhas ilusões primitivas. Rodeavam-no, ofegantes, ansiosamente, mal reprimindo o desapontamento das trajetórias desviadas, toda a espécie de lutadores.

Até um médico, Alfredo Gama, não pôde forrar-se à ânsia de a apontar. Caiu vitimado. O escapamento de gases da peça mal obturada, incendiando um barril de pólvora, perto, fê-la explodir, matando-o e incinerando-o, assim como o $2^{\circ}$ tenente Odilon Coriolano e algumas praças.

Este incidente mostra como se combatia...
É natural que a refrega resultasse inútil, traduzindo-se o bombardeio, estoiraz e inofensivo, numa salva imponente à coragem dos matutos.

Ao cair da noite nada se adiantara. Verificara-se contraproducente aquele duelo à distância, ao mesmo passo que as descargas circulantes indicavam, iniludível agora a todos os combatentes, o assédio que os prendia. Era um sítio em regra - embora disfarçado no rarefeito das linhas inimigas, desatando-se, frouxas mas numerosas, em raios indefinidos pelos recostos do morro. Uma brigada, um batalhão, uma companhia mesmo, poderia vará-las pelos claros que as cindiam ou quebrá-las numa carga de baionetas; mas quando estacasse na marcha, sentir-se-ia novamente circulada, batida pelos flancos e tendo outra vez, em roda, como se brotassem do chão, os antagonistas inexoráveis, jarretando-lhe os movimentos. A tática invariável do jagunço expunha-se temerosa naquele resistir às recuadas, restribando-se em todos os acidentes da terra protetora. Era a luta da sucuri flexuosa com o touro pujante. Laçada a presa, distendia os anéis; permitia-lhe a exaustão do movimento livre e a fadiga da carreira solta; depois se constringia repuxando-o, maneando-o nas roscas contráteis, para relaxá-las de novo, deixando-o mais uma vez se esgotar no escarvar, a marradas, o chão; e novamente o atrair, retrátil, arrastando-o — até ao exaurir completo...

Havia ali uma inversão de papéis. Os homens aparelhados pelos recursos bélicos da indústria moderna é que eram materialmente fortes e brutais, jogando pela boca dos canhões toneladas de aço em cima dos rebeldes que lhes antepunham a esgrima magistral de inextricáveis ardis. Davam de bom grado aos adversários o engodo das vitórias inúteis, mas quando eles, depois de calçarem à bala o solo das caatingas, desdobravam bandeiras e enchiam os ermos quietos de toques de alvorada, como não possuíam esses requintes civilizados, compassavam-lhes os hinos triunfais com as balas ressoantes dos trabucos..

O canhoneio de 29 não os abalara. Ao alvorecer de 30 todo o acampamento foi investido. Foi, como sempre, um choque, um sobressalto instantâneo, eterno reproduzir dos mesmos fatos. Aprontou-se mais uma vitória. Os inimigos, que rolavam de todos os lados, foram repelidos para todos os lados. Para voltarem horas depois, e serem ainda rechaçados; e retornarem, passado breve intervalo, e serem novamente repulsados intermitentemente, ritmicamente, feito o fluxo e refluxo de uma onda, 
batendo, monótona, os flancos da montanha. A artilharia, como na véspera, espalhou algumas balas sobre os tetos, embaixo. E uma fuzilaria frouxa, irradiando de lá e dos cerros próximos, como na véspera, sem variante alguma, caiu durante o dia sobre a tropa...

\section{Regime de privações}

Firmara-se definitivamente um regime insustentável. A estadia na Favela era sobremaneira inconveniente porque, além de acumular baixas diárias sem efeito algum, desmoralizava dia a dia a expedição, lhe malsinava o renome e tornar-se-ia em breve inaturável pelo esgotamento completo das munições. Abandoná-la era deixar as contingências de um cerco mais perigosas que as alternativas da batalha franca. Alguns oficiais superiores sugeriram então a única medida — forçada e urgente - a alvitrar-se: o assalto imediato ao arraial.

Seja, porém, como for, no dia 30 de junho as forças estavam bem dispostas; a artilharia podia continuar a bombardear Canudos durante algumas horas ainda; em seguida era possível levar-se um ataque à cidadela. Havia para isto a melhor disposição dos comandantes das colunas, brigadas e corpos e dos oficiais subalternos e dos soldados cuja aspiração predominante era atingir o Vaza-Barris que lhes representava a abundância de que se achavam privados numa posição acanhada, enfiada por toda a parte, sem capacidade para dois quanto mais perto de 6 mil homens ${ }^{1}$.

O general-em-chefe, porém, repeliu o alvitre “acreditando que de Monte Santo chegasse, em breve, um comboio de gêneros alimentícios como lhe afiançara o deputado do Quartel-Mestre-General e só então, depois de três dias de ração completa, investiria sobre os baluartes do Conselheiro".

Mas esse comboio não existia. Enviada a seu encontro, no dia 30, a brigada do coronel Medeiros, para o aguardar nas Baixas e dali o proteger até ao acampamento, aquele comandante, nada encontrando, prosseguiu na jornada para Monte Santo onde também nada existia. E o exército, que à sua partida já sofria os primeiros aguilhões da fome, entrou num período de provações indescritíveis.

${ }^{1}$ Coronel Dantas Barreto, Última expedição a Canudos.

\section{Aventuras do cerco. Caçadas perigosas}

Vivia-se à aventura, de expedientes. De moto próprio, sem a formalidade, na emergência dispensável, de uma licença qualquer, os soldados principiaram a realizar, isolados ou em pequenos grupos, excursões perigosas pelas cercanias talando as raras roças de milho ou mandioca, que existiam; caçando cabritos quase selvagens por ali desgarrados, em abandono desde o começo da guerra; e arrebanhando o gado. Não havia evitá-las ou proibi-las. Eram o último recurso. A partir de 2 de junho só houve gêneros - farinha e sal, nada mais — para os doentes. As caçadas faziam-se, pois, obrigatoriamente, a despeito dos maiores riscos e os que a elas se abalançavam - vestindo a pele do jagunço, copiando-lhe a astúcia requintada, a marcha cautelosa, acobertando-se em todos os sulcos do terreno - aventuravam-se a extremos lances temerários.

Não se podem individuar os episódios parciais desta fase obscura e terrível da campanha. O soldado faminto, cevada a cartucheira de balas, perdia-se nas chapadas, presumindo-se de resguardos como se fosse à caça de leões. Atufava-se no bravio das moiteiras... Rompia a galhada inflexa, entressachada de gravatás mordentes. E - olhos e ouvidos armados aos mínimos contornos e aos mínimos rumores - atravessava longas horas na perquisição exaustiva...

Às vezes era um esforço vão. Volvia à noite para o acampamento, desinfluído e com as mãos vazias. Outros, mais infelizes, não apareciam mais, perdidos por aqueles ermos; ou mortos nalguma luta feroz, para todo o sempre ignorada. Porque os jagunços por fim opunham tocaias imprevistas aos caçadores bisonhos que sem lhes pleitearem parelhas na ardileza, não lhas evitavam.

Assim é que, não raro, depois de muitas horas de esforço inútil, o valente faminto dava tento, afinal, de um ressoar de cincerros, pressagos da caça apetecida, porque é costume trazerem-nos as cabras, no sertão; e reanimava-se esperançado.

Recobrava-se um momento das fadigas. Refinando no avançar cauteloso, por não espantar a presa fugidia, retraía-se das trilhas descobertas para o âmago das macegas. Seguia serpejando, deslizando devagar, guiado pelas notas da campainha, a pontilharem, nítidas e claras, o silêncio das 
chapadas. Adiantava-se até as ouvir perto... e era feliz, em que pese à dolorosa contrariedade, se as ouvia novamente ao longe, indistintas, inatingíveis, ao través do embaralhado dos desvios. Porque não imaginava, em certas ocasiões, os riscos que corria: a um lado, nos recessos da caatinga, em vez do animal arisco negaceava, sinistro e traiçoeiro, procurando-o por sua vez, o jagunço. Acaroado com o chão, rente da barba a fecharia da espingarda e avançando de rastros, quedo e quedo entre as macegas, e fazendo a cada movimento tanger o cincerro que apresilhara ao próprio pescoço, via-se, ao invés da cabra, o cabreiro feroz. A caça caçava o caçador. Este, inexperto, caía, geralmente abatido por um tiro seguro, a não ser que atirasse primeiro sobre o vulto lobrigado no último momento.

Outras vezes ante um grupo de famintos aparecia, num revesso de colina, uma mangueira fechada. Dentro, alguns bois, presos. Eram um chamariz ardilosamente disposto: e o cercado uma arapuca grande. Ante a imprevista descoberta, porém, mal desfechavam, aqueles, olhos indagadores em roda. Transpunham num pulo as cercas do curral. Arremetiam com os bois, abatendo-os a tiro ou jugando-os à faca... e espalhavam-se, tontos, alarmados, batidos de descargas envolventes, partidas das esperas, adrede predispostas aos lados...

No acampamento ouviam-se muitas vezes tiroteios nutridos e longos, com ecos de combates.

Estas aventuras ao cabo foram regulamentadas. As ordens de detalhe escalavam, de véspera, os batalhões para as caçadas. Eram verdadeiras sortidas de praças de armas em apuros. Mas inglórias. Um triste avançar sem bandeiras e sem clarins pela maninhez dos ermos. As linhas inimigas dobravam-se-lhes em frente, ralas, invisíveis, traidoras. Os corpos em diligencia escoavam-se-lhes pelos claros. Batiam longo tempo a terra, onde a entrada da estação sem chuvas se refletia já na flora emurchecida. Recebiam meia dúzia de tiros de adversários incorpóreos.

\section{Voltavam abatidos e exaustos.}

Apenas o esquadrão de lanceiros agia com algum efeito. Partia diariamente em batidas longas pelos arredores. Montando cavalos estropiados, que rengueavam sob a espora, os gaúchos faziam façanhas de pealadores. Largavam, sem medir distâncias e perigos, pela região desconhecida; e, conseguindo sopear na carreira os bois esquivos, lançavam-nos em tropel, todas as tardes, para dentro de uma caiçara, à ilharga do acampamento. O inimigo perturbava-lhes a montaria. Além do trabalho de reunir as reses espantadiças, tinham o de impedir a sua dispersão ante súbitos assaltos. E nestes recontros rápidos e violentos, contendo do mesmo passo os bois alvorotados prestes a espalharem-se por toda a banda, e replicando, a disparos de mosquetão, às tocaias que os aferroavam; caindo, surpresos, numa tocaia ao transpor uma baixada, alvejados por um tiroteio subitamente partindo do alto; e não abandonando nunca a presa irrequieta; circulando-a, arremessando-a para diante e ao mesmo tempo contendo-a pelos flancos, fizeram prodígios de equitação e bravura.

O gado diariamente adquirido - oito a dez cabeças - era, porém, um paliativo insuficiente ao minotauro de 6 mil estômagos. Além disto, a carne cozida sem sal, sem ingrediente algum, em água salobra e suspeita, ou chamuscada em espetos, era quase intragável. Repugnava à própria fome.

As pequenas roças de milho, feijão da vazante e mandioca, que atenuavam a princípio a sensaboria dessa alimentação de feras, exauriramse prestes. Tornou-se necessário buscar outros recursos.

Como os retirantes infelizes, os soldados apelaram para a flora providencial. Cavavam os umbuzeiros em roda, arrancando-lhes os tubérculos túmidos; catavam cocos dos ouricuris, ou talhavam os caules moles dos mandacarus, alimentando-se de cactos que a um tempo lhes disfarçavam ou iludiam a fome e a sede. Não lhes bastava, porém, este recurso, que para os mais inexpertos mesmo era perigoso. Alguns morreram envenenados pela mandioca brava e outras raízes, que não conheciam.

Por fim a própria água faltava — tornando-se de aquisição dificílima. Nos regatos rasos do Vale das Umburanas, não raro ficava de bruços, varado por um tiro, o soldado sequioso.

Cada dia que passava aumentava esses transes. A partir de 7 de junho, cessou a distribuição de gêneros aos doentes

E os infelizes, mutilados, estropiados, abatidos de febres, começaram a viver da esmola incerta dos próprios companheiros... 


\section{Desânimos}

À medida que se agravavam estes fatos, surgiam, consequentes, outros, igualmente sérios. Relaxava-se a disciplina; esgotava-se a resignação da soldadesca. Uns murmúrios afrontosos de protestos, ante os quais se fingia surda a oficialidade impotente para os fazer calar, surgiam irreprimíveis, inevitáveis, como borborigmos dos ventres vazios.

Por um contraste irritante, os adversários batidos em todos os combates afiguravam-se fartamente abastecidos, ao ponto de aproveitarem apenas nos comboios assaltados as munições de guerra. A $5^{\text {a }}$ Brigada, ao seguir certa vez até às Baixas, encontrara em suas vizinhanças, orlando os caminhos até próximo ao Angico, malas de carne seca esturradas, montes de farinha, café e açúcar, de mistura com as cinzas das fogueiras que os haviam consumido. Era um traço firme de altivez selvagem com que se arrojavam à luta os jagunços que, afinal, não tinham abastança tal que justificasse tais atos. Afeitos, porém, às parcimônias de frugalidade sem par, os rudes lidadores, que nas quadras benignas atravessavam o dia com três manelos de paçoca e um trago d'água, haviam refinado a abstinência disciplinadora, na guerra, ostentando uma capacidade de resistência incomparável. Os nossos soldados não a tinham. Não podiam tê-la. A princípio reagiram bem. Deram um epíteto humorístico à fome. Distraíramse nas aventuras perigosas das caçadas ou no rastrear os rebutalhos das roças em abandono. Ao soar dos alarmas precipitavam-se às linhas de fogo, sem que o jejum lhes sopeasse o arrojo. Depois fraquearam. Sobre o aniquilamento físico descia dolorosa incerteza do futuro. Estavam em função da sorte de uma brigada única, a $1^{\mathrm{a}}$, que seguira à descoberta do comboio e da qual nada se sabia. Cada dia que passava sem novas de sua vinda sobrecarregava-lhes os desalentos. Além disto a insistência inflexível dos ataques tornara-se inaturável. Não havia uma hora de tréguas. Surgiam investidas súbitas à noite, pela manhã, no correr do dia, sempre improvisas, incertas e variáveis; carregando às vezes sobre a artilharia, outras sobre um dos flancos, outras, mais sérias, por toda a banda. Estridulavam os clarins; formava a tropa toda em fileiras bambas, em que mal se distinguiam as menores subdivisões táticas, e batia-se nervosamente por algum tempo. Os assaltantes eram repelidos. Caía-se, de improviso, na calma anterior. Mas o inimigo ali ficava, a dois passos, sinistramente, acotovelando os triunfadores. Cessava o ataque. Mas de minuto em minuto, com precisão inflexível, caía uma bala entre os batalhões. Variava vagarosamente de rumo, percorrendo a pouco e pouco todas as linhas, de um a outro flanco, num giro longo e torturante, indo e vindo, devagar, traçando ponto a ponto o círculo espantoso, como se um atirador único, ao longe, do alto de algum cerro remoto, houvesse o compromisso bárbaro de ser o algoz de um exército. E era-o. Valentes ainda ofegantes de recontros em que entravam intrêmulos, estremeciam, por fim, ante o assovio daqueles projetis esparsos, transvoando ao acaso para o alvo imenso, escolhendo, entre milhares de homens, um vítima qualquer...

\section{Assalto ao acampamento. A “matadeira”}

E iam-se assim os dias, nesse intermitir de refregas furiosas e rápidas, e longas reticências de calma, pontilhadas de balas...

Os assaltos, às vezes, contra toda a expectativa, não cessavam logo. Num crescendo aterrador, agitavam todas as linhas e tinham vislumbres de batalha. Num deles, a $1 .^{\circ}$ de julho, os sertanejos penetraram em cheio o acampamento até ao centro das baterias. O ódio votado aos canhões, que dia a dia lhes demoliam os templos, arrebatara-os à façanha inverossímil, visando a captura ou a destruição do maior deles, o Whitworth 32, a matadeira, conforme o apelidavam. Foram poucos, porém, os que se abalançaram à empresa. Onze apenas, guiados por Joaquim Macambira, filho do velho cabecilha de igual nome. Mas ante o grupo diminuto formaram-se batalhões inteiros. Deram-se cargas cerradas de baionetas a toques de corneta, como se fosse uma legião; até que baqueassem todos, salvo um único, que escapou miraculosamente, varando pelas fileiras agitadas.

A tropa teve o adminículo de mais uma vitória pouco lisonjeira e acrescido o respeito ao destemor do adversário.

O ascendente deste avultava dia a dia. Descobriam-se, mais próximas, avançando num constringir vagaroso, as trincheiras circulantes: pela esquerda, trancando o passo para a Fazenda Velha; pela direita, ameaçando o posto de carneação e reduzindo a área do pequeno pasto em que estavam os animais de tração e montaria; e pela retaguarda, aproximando-se pelo caminho do Rosário. Os corpos destacados para as tomar e demolir tomavam-nas e demoliam-nas facilmente. Tornavam com 
poucas baixas ou de todo indenes. E no dia subsequente volviam à mesma tarefa, reconstruídos durante a noite, e cada vez mais próximos, os entrincheiramentos ameaçadores.

Enquanto se empregavam de tal modo os dias, reservavam-se as noites para o enterramento dos mortos, missão, além de lúgubre, perigosa, em que não raro o carregador aumentava a carga, caindo por sua vez entre os cadáveres, baqueando dentro da vala comum, que com as próprias mãos abria.

É natural que uma semana depois da ocupação do morro se generalizasse o desânimo. Afrouxamento em toda a linha. A própria artilharia, verificando-se a ineficácia do canhoneio e a necessidade de poupar a munição reduzida, apenas atirava, certos dias, dois ou três tiros longamente espaçados...

\section{Atitude do comando-em-chefe}

Aguardava-se a brigada salvadora. Se por um golpe de mão, que o inimigo podia e não soube dar, ela tivesse cortado a marcha nas cercanias do Rosário ou do Angico, a expedição estaria perdida. Era a convicção geral. O estado da força facultava ainda uma defesa frouxa daquela posição, mas impossibilitava-lhe prolongar esse esforço por mais de oito dias. Somente o prestígio de alguns chefes de corpos a salvava da desorganização completa. Ficara em algumas brigadas, dominando a indisciplina emergente, a dedicação pessoal aos comandantes.

O general Artur Oscar, que se obstinara a permanecer ali iludido, a princípio, pela miragem de um comboio, justificava-se, agora, pela impossibilidade absoluta de se mover.

Estadeou então a sua única qualidade militar frisante: a tendência a enraizar-se nas posições conquistadas. Este atributo contrasta com qualidades pessoais opostas. Irrequieto e ruidosamente franco; encarando a profissão das armas pelo seu lado cavalheiresco e tumultuoso; quase fanfarrão, embora valente, no relatar façanhas de pasmar; incomparável, no idear surpreendedores recontros; encontrando sempre nas conjunturas mais críticas uma frase explosiva, que as sublinha com traço vigoroso de jovialidade heroica, num calão pitoresco e incisivo e vibrante; patenteando sempre, insofridas, todas as impaciências e todos os arrojos de um temperamento nervoso e forte; - aquele general, numa campanha, no meio de cultura por excelência de tão notáveis requisitos, se transmuda, e, com espanto dos que o conhecem, só tem uma tática — a da imobilidade.

Resiste; não delibera.

Inflexivelmente imóvel diante do adversário, não o perturba com as sortidas bem combinadas e o arremesso das cargas; opõe-lhe a força emperradora da inércia.

Não o combate; cansa-o. Não o vence; esgota-o.

Guiando a expedição, concentrou-se inteiramente no objetivo da luta: absorveu-se desde o começo na sua fase derradeira, abstraindo de todas as circunstâncias intermediárias; e, realizando uma investida original, sem bases e sem linhas de operações, não preestabeleceu a hipótese de um insucesso, a necessidade eventual de um recuo.

Tinha um plano único - ir a Canudos. Tudo mais era secundário. Levando 6 mil baionetas à margem do Vaza-Barris, ganharia a partida, de qualquer modo, desse por onde desse. Não recuaria. Alterou um verbo na frase clássica do romano e seguiu.

Chegou; viu; e ficou.

Se no dia 28 o erro serodiamente corrigido do abandono do comboio lhe vedava marchar à investida, no dia 30, segundo o depoimento dos seus melhores auxiliares, devia tê-la feito. Não a fez. Entretanto estavam, afinal, reunidas as duas colunas e o arraial desdobrava-se à distância de um tiro de Mannlicher. Completou, assim, com um erro outro, colocando-se em situação insustentável, de onde, se não ocorresse o curso caprichoso dos acontecimentos, talvez não mais saísse.

Não desanimara, porém. Compartia o destino comum resignado, estoico, inflexível, imóvel ..

"Não lhe afrouxara o garrão!..." frase predileta, que despedia violentamente, como um golpe de sabre, despedaçando o fio dos comentários mais desalentados, ou desalentadoras conjeturas. 
Mas presa nos liames de um assédio extravagante, cujas linhas se distendiam elásticas, ante todas as cargas, e se ligavam logo depois de serem rotas, em todos os pontos; exausta de fazer recuar o adversário, sem o esmagar nunca; sentindo engravescer-se a sua situação precária, a tropa não resistiria. Afrouxava. Surgiam já, traduzindo-se em alusões acerbas, surdos rancores contra imaginários responsáveis por aquelas desventuras. O deputado do Quartel-Mestre-General foi, então e depois, a vítima expiatória de todos os desmandos. Era o único culpado, comentava o desquerer geral. Não se ponderava que a acusação ilógica refluía toda sobre o comando-emchefe, do qual a absolvição pressupunha uma culpa maior — o olvido da sua autonomia incondicional de chefe.

De feito, aquele funcionário tinha, pela permanência no cargo, a sua confiança plena. E, empunhando febrilmente o lápis calculista com que floreteava a impaciência geral, permanecia, estéril, na Favela: somando, subtraindo, multiplicando e dividindo; pondo em equação a fome; discutindo estupendas soluções sobre cargueiros fantásticos; diferenciando a miséria transcendente; arquitetando fórmulas admiravelmente abstratas com sacos de farinha e malas de carne seca; idealizando comboios...

Era todo o esforço. Não havia notícias da $1^{\text {a }}$ Brigada. Os batalhões, diariamente mandados até as Baixas, voltavam sem rastrear nem um sinal da sua existência, pelas estradas vazias. Um deles, o $15^{\circ}$, comandado pelo capitão Gomes Carneiro, no dia 10, ao tornar da diligência inútil, comboiara como suprema irrisão um boi, um único boi - magro, retransido de fome, oscilante sobre as pernas secas - uma arroba de carne para 6 mil famintos...

\section{Outro olhar sobre Canudos}

E sobre tudo aquilo uma monotonia acabrunhadora... A sucessão invariável das mesmas cenas do mesmo cenário pobre, despontando às mesmas horas com a mesma forma, dava aos lutadores exaustos a impressão indefinível de uma imobilidade no tempo.

À tarde ou durante o dia, nos raros momentos em que se atreguavam os assaltos, alguns se distraíam contemplando o arraial intangível. Lá se iam, então, cautelosamente, desenfiando-se pelo viés das encostas, alongando as distâncias, para atingirem com resguardos um ponto abrigado qualquer de onde o distinguissem a salvo. Perturbavam-se-lhes, então, as vistas, no emaranhado dos casebres, esbatidos embaixo. E contavam: 1, 2, 3, 4 mil, 5 mil casas! Cinco mil casas ou mais! Seis mil casas, talvez! Quinze ou 20 mil almas - encafurnadas naquela tapera babilônica... E invisíveis. De longe em longe, um vulto, rápido, cortava uma viela estreita, correndo, ou apontava, por um segundo, indistinto e fugitivo, à entrada da grande praça vazia, desaparecendo logo. Nada mais. Em torno o debuxo misterioso de uma paisagem bíblica: a infinita tristura das colinas desnudas, ermas, sem árvores. Um rio sem águas, tornejando-as, feito uma estrada poenta e longa. Mais longe, avassalando os quadrantes, a corda ondulante das serras igualmente desertas, rebatidas, nitidamente, na imprimadura do horizonte claro, feito o quadro desmedido daquele cenário estranho.

Era uma evocação. Como se a terra se ataviasse em dados trechos para idênticos dramas, tinha-se, ali, o que quer que era recordando um recanto da Iduméia, na paragem lendária que perlonga as ribas meridionais do Asfaltite, esterilizada para todo o sempre pelo malsinar fatídico dos profetas e pelo reverberar adusto dos plainos do Iêmen...

O arraial — “compacto" como as cidades do Evangelho completava a ilusão.

Ao cair da noite, de lá ascendia, ressoando longamente nos descampados em ondulações sonoras, que vagarosamente se alargavam pela quietude dos ermos e se extinguiam em ecos indistintos, refluindo nas montanhas longínquas, o toque da Ave-Maria...

Os canhões da Favela bramiam, despertos por aquelas vozes tranquilas. Cruzavam-se sobre o campanário humilde as trajetórias das granadas. Estouravam-lhe por cima e em roda os shrapnels. Mas lento e lento, intervaladas de meio minuto, as vozes suavíssimas se espalhavam, silentes, sobre a assonância do ataque. O sineiro impassível não claudicava um segundo no intervalo consagrado. Não perdia uma nota.

Cumprida, porém, a missão religiosa, apenas extintos os ecos da última badalada, o mesmo sino dobrava estridulamente sacudindo as vibrações do alarma. Corria um listrão de flamas pelas cimalhas das igrejas. Caía feito um rastilho no arraial. Alastrava-se pela praça deflagrando para as faldas do morro; abrangia-as; e uma réplica violenta caía estrepitosamente sobre a tropa. Fazia calar o bombardeio. O silêncio descia 
amortecedoramente sobre os dois campos. Os soldados escutavam, então, misteriosa e vaga, coada pelas paredes espessas do templo meio em ruínas, a cadência melancólica das rezas...

\section{Desânimo}

Aquele estoicismo singular impressionava-os, e dominava-os; e como tinham, mal esvaecidas na alma, as mesmas superstições e a mesma religiosidade ingênua, vacilavam por fim ante o adversário que se aliara à Providência.

Imaginavam-lhe recursos extraordinários. As próprias balas que usavam revelavam efeitos extravagantes. Crepitavam nos ares com estalidos secos e fortes, como se arrebentassem em estilhaços inúmeros. Criou-se, então, a lenda, depois insistentemente propalada, das balas explosivas dos jagunços. Tudo a sugeria. Aceita ainda a hipótese de previrem os estalos do desigual coeficiente de dilatação entre os metais constituintes do projétil, expandindo-se o núcleo de chumbo mais rapidamente do que a camisa de aço, a natureza excepcional dos ferimentos afigurava-se eloquentíssima: a bala, que penetrava os corpos mal deixando visível o círculo do diminuto calibre, saía por um rombo largo de tecidos e ossos esmigalhados. Tais fatos arraigavam na soldadesca, inapta ao apercebimento da lei física que os explicava, a convicção de que o adversário, terrivelmente aparelhado, requintava no estadear a selvageria impiedosa.

\section{Deserções heroicas}

Principiaram as deserções. Deserções heroicas, incompreensíveis quase, em que o soldado se aventurava aos maiores riscos, sob a fiscalização incorruptível do inimigo. No dia 9, vinte praças do $33^{\circ}$ deixaram os companheiros, afundando no deserto. E, uma a uma, diariamente, outras as imitaram, preferindo o tiro de misericórdia do jagunço àquela agonia lenta.

Havia permanente em todos os espíritos o desejo absorvente de deixar afinal aquela paragem sinistra da Favela.

Os batalhões que abalavam em diligência para vários pontos despertavam inveja aos que ficavam. Invejavam-lhes os perigos, as emboscadas, os combates. Tinham ao menos a esperança das presas acaso conquistadas. Viam-se por algum tempo fora do quadro miserando que o acampamento patenteava.

Como nos maus dias dos cercos lendários, rememorados em velhas crônicas, os gêneros mais vulgares adquiriam cotações fantásticas: uma raiz de umbu ou uma rapadura valiam como iguarias suntuárias. Um cigarro reles era um ideal de epicurista.

Falava-se, às vezes, na retirada. O boato surdo, cochichado a medo, por algum desesperado que atirava, anônimo, aquela consulta vacilante aos companheiros penetrava sussurrando, insidioso, entre os batalhões, despertando ora apóstrofes e protestos violentos, ora um silêncio comprometedor e suspeito. Mas a retirada era inexequível. Uma brigada ligeira podia, impune ,varrer os arredores, ir tiroteando para qualquer ponto, e voltar. O exército, não. Se o tentasse, com o tardo movimento que lhe impunham a artilharia, as ambulâncias e o contrapeso de mil e tantos feridos - consumar-se-ia a catástrofe.

Ficar, a despeito de tudo, era o recurso supremo e único.

Se a $1^{\text {a }}$ a Brigada, porém, retardasse por mais oito dias a vinda nem este restaria. Os jagunços partiriam, afinal, num dos assaltos, as linhas de fogo dos soldados inteiramente exaustos...

\section{Um choque galvânico na expedição combalida}

Na tarde de 11 de julho, porém, um vaqueiro, escoltado por três praças de cavalaria, apareceu inesperadamente no acampamento. Trazia um ofício do coronel Medeiros notificando a sua vinda e requisitando forças necessárias à proteção do grande comboio que puxava.

Foi um choque galvânico na expedição combalida.

Não há descrevê-lo. De uma à outra ponta das alas, correu, empolgante, a nova auspiciosa e, transfigurados os rostos abatidos, corretas as posturas dobradas, movendo-se febrilmente em alacridade imensa, exposta em abraços, em gritos, em estrepitosas exclamações, entrecruzaram-se em todos os sentidos os lutadores. Desdobraram-se as 
bandeiras. Ressoaram os clarins, tocando a alvorada. Formavam as bandas de todos os corpos. Restrungiram hinos...

O vaqueiro rude, vestido de couro, montando no campião suarento e resfolegante, empunhando ao modo de lança a guiada longa, olhava surpreendido para tudo aquilo. A sua corpulência de atleta contrastava com os corpos mirrados que turbilhonavam em roda. Lembrava um gladiador possante entre boximanes irrequietos.

A torrente ruidosa das aclamações rolou até à sanga do hospital de sangue. Os doentes e os moribundos calaram os gemidos - transmudandoos em vivas...

O nordeste soprando rijo ruflava as bandeiras ondulantes; e arremessava sobre o arraial, misturadas, baralhadas, as notas metálicas das bandas marciais e milhares de brados de triunfo...

Descia a noite. De Canudos ascendia — vibrando longamente pelos descampados num ondular sonoro, que vagarosamente avassalava o silêncio dos ermos e se extinguia a pouco e pouco em ecos indistintos refluindo nas montanhas longínquas - o toque da Ave-Maria...

\section{Capítulo V}

\section{O assalto: preparativos}

O comboio chegou ao alto da Favela a 13 de julho; e no dia subsequente, convocados os comandantes de brigadas, na tenda do general Savaget, enfermo do ferimento recebido em Cocorobó, concertaram sobre o assalto. O dia era propício: uma data de festa nacional. Logo pela manhã uma salva de 21 tiros de bala a comemorara. Os matutos broncos foram varridos cedo - surpreendidos, saltando estonteadamente das redes e dos catres miseráveis - porque havia pouco mais de cem anos um grupo de sonhadores falara nos direitos do homem e se debatera pela utopia maravilhosa da fraternidade humana...

\section{$\mathrm{O}$ ataque contra $\mathrm{o}$ arraial era urgente.}

O comandante da $1^{\text {a }}$ Brigada ao voltar comunicara que na pretensa base de operações nada existia. Encontrara-a desprovida de tudo, tendo-lhe sido necessário organizar com dificuldades o comboio que trouxera. Este em pouco se esgotaria e volver-se-ia de novo à crítica situação anterior.

Deliberou-se. As opiniões, dissentindo em minúcias, firmaram-se acordes no pensamento da investida em grandes massas por um único flanco. Os comandantes da $3^{\mathrm{a}}$, $4^{\mathrm{a}}$, e $5^{\mathrm{a}}$ Brigadas opinaram pelo abandono preliminar da Favela por uma posição mais próxima de onde, depois, empenhassem a ação. Os demais, fortalecidos pelo voto favorável dos três generais, contravieram: permaneceriam na Favela o hospital de sangue, artilharia e duas brigadas, garantindo-os.

Este alvitre, que afinal pouco divergia do primeiro, prevaleceu. Reincidia-se num erro. O inimigo ia ter, mais uma vez, diante da sua fugacidade a potência ronceira das brigadas. Havia, como se vê, persistente na maioria dos ânimos, o intento de se não executar o que a campanha, desde o começo, reclamava: a divisão dos corpos combatentes. $\mathrm{O}$ ataque por dois pontos, pelo caminho de Jeremoabo e pela extrema esquerda, derivando pelos contrafortes da Fazenda Velha, enquanto a artilharia, sem deixar a sua posição, agisse, bombardeando pelo centro, surgia, entretanto, como único plano - imperioso e intuitivo - à mais ligeira observação do 
teatro da luta. Não se cogitou, porém, de observar o teatro da luta. O plano firmado era mais simples. As duas colunas combatentes, após uma marcha de flanco de quase dois quilômetros para a direita do acampamento, que se preestabeleceu realizada sem que a perturbasse o inimigo, obliquariam à esquerda, demandando o Vaza-Barris. Dali, volvendo ainda à esquerda, arremeteriam em cheio até à praça das igrejas. O movimento, contornante a princípio, ultimar-se-ia em trajetória retilínea; e se fosse impulsionado com sucesso favorável, os jagunços, mesmo no caso de inteiro desbarate, teriam, francos ao recuo, três ângulos do quadrante. Poderiam, a salvo, deslocar-se para as posições inacessíveis do Caipã, ou qualquer outra de onde renovassem a resistência.

\section{Esta era certa e previa-se a todo o transe.}

Diziam-no acontecimentos recentes. Duas semanas de canhoneio e o reforço de munições aos adversários não tinham desinfluído os sertanejos. Revigoraram-nos. No dia 15, como se ideassem atrevida paródia à recente vinda do comboio, foram vistos, em bandos, em que se incluíam mulheres e crianças, avançando pela direita do acampamento, tangendo para o arraial numerosas reses. O 25 Batalhão, enviado a atacá-los, não os alcançara. Naquele mesmo dia, os expedicionários, fartos e alentados de novo pela esperança da vitória próxima, não tiveram permissão de andar à vontade na própria posição em que acampavam. A travessia de um para outro abarracamento era a morte. Tombaram, baleados, o sargento-ajudante do $9^{\circ}$ e várias praças. Foi assaltado o pasto, a dois passos da $2^{\mathrm{a}}$ coluna, e capturados alguns animais de montaria e tração, sem que os retomasse o $30^{\circ}$ de Infantaria, imediatamente destacado para a diligência. A 16 ostentaram o mesmo afoitar-se desafiador com o adversário abastecido. Bateram todas as linhas. A comissão de engenheiros, para fazer ligeiros reconhecimentos nas cercanias, fê-lo combatendo, levando a escolta formidável de dois batalhões, o $7^{\circ}$ e o $5^{\circ}$. Esta atitude indicava-os dispostos a reagir com vigor; e como se não conheciam os recursos que contavam, o ataque planeado devia ater-se à condição essencial de não ser nele, de chofre, comprometida toda a força, o que ademais impropriava a zona mesma do combate. Vista do alto da Favela, esta parecia ser, de fato, a de mais fácil acesso. Apesar disto, o solo, pregueado de sangas e ondeando em outeiros, impossibilitava o desdobramento rápido das colunas; permitia prever-se o travamento forçado da investida em massa e sugeria por si mesmo, como corretivo único à sua conformação especial, a ordem largamente dispersa. Mas esta só seria factível se, excluído de todo o alvitre das cargas de pelotões maciços, precipitando-se contra os cerros, a batalha tivesse a preliminar de uma demonstração preparatória ou reconhecimento enérgico feito por uma brigada única livremente desenvolvida e agindo fora da compreensão entibiadora de fileiras compactas e inúteis. Esta vanguarda combatente à medida que progredisse, varrendo as trincheiras abertas em todos os altos e em todas as encostas, seria gradativamente seguida pelas outras, que a reforçariam nos pontos mais convenientes, até se operar, afinal, naturalmente, na própria esteira do recuo do antagonista, a concentração de todas, dentro do arraial. Ia fazer-se o contrário. O comandante-geral oscilava entre extremos. Saía da anquilose para o salto; da inércia absoluta para os movimentos impulsivos. Deixou a vacilação inibitória, que o manietava no alto da Favela, para a obsessão delirante das cargas. Nas disposições, dadas a 16, para o combate, são elas a nota preponderante. Postos em plano inferior todos os dispositivos que garantissem o desenlace do recontro, espelha-se ali, a preocupação absorvente dos choques violentos: 3 mil e tantas baionetas rolando, como uma caudal de ferro e chamas, pelo leito do Vaza-Barris em fora...

Dado o sinal da carga ninguém mais procura evitar a ação dos fogos do inimigo. Carrega-se sem vacilar com a maior impetuosidade. Depois de cada carga cada soldado procura a sua companhia, cada companhia o seu batalhão e assim por diante.

Estas instruções iam de nível com as tendências gerais. As longas combinações concretas de um combate, adrede elaboradas consoante as condições excepcionais do meio e do adversário, não as satisfaziam. O rancor longamente acumulado por anteriores insucessos exigia revides fulminantes. Era preciso levar às recuadas os bandidos tontos e, de uma só vez, de pancada, socá-los dentro da cova de Canudos, a coices de armas.

A ordem do dia 17 de julho marcando o ataque para o imediato, 18, foi recebida com delírio. Esteando-se nas façanhas anteriores, o comandante-em-chefe, numa dedução atrevida, voltava uma página do futuro e punha diante dos lutadores a miragem da vitória.

Valentes oficiais e soldados da forças expedicionárias no interior do Estado da Bahia! 
Desde Cocorobó até aqui o inimigo não tem podido resistir à vossa bravura. Atestam-no os combates de Cocorobó, Trabubu, Macambira, Angico, dois outros no alto da Favela e dois assaltos que o inimigo trouxe à artilharia.

Amanhã vamos batê-lo na sua cidadela de Canudos. A pátria tem os olhos fitos sobre vós, tudo espera da vossa bravura. O inimigo traiçoeiro, que não se apresenta de frente, que combate-nos sem ser visto, tem, contudo, sofrido perdas consideráveis. Ele está desmoralizado, e, pois ,se...

Paremos um momento diante de uma condicional comprometedora. Ante ela a ordem do dia, lida com aplausos a 17, devia ter sido trancada ao cair da noite de 18 .

... se tiverdes constância, se ainda uma vez fordes os bravos de todos os tempos, Canudos estará em vosso poder amanhã; iremos descansar e a Pátria saberá agradecer os vossos sacrifícios.

Canudos cairia no dia seguinte. Era fatal. O inimigo mesmo parecia ciente da resolução heroica: cessara os tiroteios irritantes. Acolhia-se embaixo, timorato e quedo, vencido de véspera. $\mathrm{O}$ acampamento não fora atormentado. À tarde as fanfarras dos corpos vibraram harmoniosamente até cair a noite.

\section{Plano do assalto}

Delineou-se o ataque. Ficaram na Favela cerca de 1.500 homens sob o mando geral do general Savaget, guardando a posição: a $2^{\mathrm{a}}$ e $7^{\mathrm{a}}$ Brigadas dos coronéis Inácio Henrique de Gouveia e Antonino Nery, a última recémformada, assim como a de artilharia, que secundaria o ataque num bombardeio firme.

A $1^{\text {a }}$ a coluna dirigida pelo general Barbosa marcharia na frente para o combate encalçada logo pela ala de cavalaria e uma divisão de dois Krupps de 71/2. A $2^{\mathrm{a}}$ acompanhá-la-ia fechando a retaguarda.

Entravam na ação 3.349 homens repartidos em cinco brigadas: a $1^{\text {a }}$, do coronel Joaquim Manuel de Medeiros, composta de dois batalhões apenas, o $14^{\circ}$ e o $30^{\circ}$, respectivamente comandados pelo capitão João Antunes Leite e tenente-coronel Antônio Tupi Ferreira Caldas; a $3^{\mathrm{a}}$, do tenente-coronel Emídio Dantas Barreto, reunia o $5^{\circ}, 7^{\circ}, 9^{\circ}$ e $25^{\circ}$, todos chefiados por capitães, Antônio Nunes de Sales, Alberto Gavião Pereira Pinto, Carlos Augusto de Sousa e José Xavier dos Anjos; a 4a, do coronel Carlos Maria da Silva Teles, formava-se com o $12^{\circ}$ e o $31^{\circ}$ sob o mando dos capitães José Luís Buchelle e José Lauriano da Costa; a $5^{a}$, do coronel Julião Augusto da Serra Martins, que substituíra o general Savaget na direção da $2^{\mathrm{a}}$ coluna, estava sob o comando do major Nonato Seixas e constituía-se com o $35^{\circ}$ e $40^{\circ}$ Batalhões do major Olegário Sampaio e capitão J. Vilar Coutinho; e finalmente a $6^{\text {a }}$, do coronel Donaciano de Araújo Pantoja, com o $26^{\circ}$ e $32^{\circ}$ comandados pelo capitão M. Costa e major Colatino Góis. O $5^{\circ}$ de Polícia baiana, chefiado pelo capitão do exército Salvador Pires de Carvalho Aragão, acompanhava, autônomo, a $2^{a}$ coluna.

O tenente-coronel Siqueira de Meneses, com um contingente reduzido, enquanto o grosso da expedição atacasse devia operar ligeira diversão à direita, sobre os contrafortes da Fazenda Velha.

Definidos os lutadores, via-se que ali estavam alguns para os quais o sertão de Canudos era um campo estreito:

Carlos Teles, uma altivez sem par sangrando sob o cilício da farda, lembrava o belo episódio do cerco de Bagé; Tupi Caldas - nervoso, irrequieto e barulhento, trazia invejável reputação de coragem da refrega mortífera de Inhanduí, contra os federalistas do sul; Olímpio da Silveira, o chefe da artilharia, com o seu facies de estátua - face bronzeada vincada de linhas imóveis — , realizava a criação rara de um lutador modesto, impassível diante da glória e diante do inimigo, seguindo retilineamente pela vida entre o tumulto das batalhas, como obediente a uma fatalidade incoercível. Nos menos graduados uma oficialidade moça, ávida de renome, anelando perigos, turbulenta, jovial, destemerosa: Salvador Pires, comandante do $5^{\circ}$ de Polícia, que ele mesmo formara com os tabaréus robustos escolhidos nos povoados do S. Francisco; Wanderley, destinado a tombar heroicamente no último passo de uma carga temerária; Vieira Pacheco, o gaúcho intrépido que chefiava o esquadrão de lanceiros; Frutuoso Mendes e Duque Estrada, que desarticulariam pedra por pedra os muros da igreja nova; Carlos de Alencar, cujo comando se extinguiria pela morte de todos os soldados da ala de cavalaria que dirigia; e outros...

Toda essa gente aguardava com impaciência o combate. Porque o combate era a vitória decisiva. Segundo o velho hábito, os lutadores 
recomendaram aos que permaneciam na Favela que tivessem pronto o almoço, para quando tornassem da empresa fatigante..

\section{$O$ recontro}

As colunas abalaram, no dia 18, ainda alta a madrugada. Contramarchando à direita do acampamento, seguiram olhando em cheio para o levante, demandando o caminho de Jeremoabo, descendo. No fim de algum tempo, volveram à esquerda, descendo sempre, em rumo certo à borda do Vaza-Barris, embaixo. A marcha, a passo ordinário, realizava-se tranquilamente, sem a menor revelação do inimigo, como se fosse surpreendê-lo aquele movimento contornante. Apenas os dois Krupps, rangendo emperradamente na vereda mal gradada, a perturbavam, às vezes. Eram tropeços breves, porém, prestamente removidos. O tropear da investida rolava surdamente, ameaçador, contínuo...

A terra despertava triste. As aves tinham abandonado, espavoridas, aqueles ares varridos, havia um mês, de balas. A manhã surgia rutilante e muda. Desvendava-se, a pouco e pouco, a região silenciosa e deserta: cômoros despidos ou chapadas breves; caatingas decíduas, pintando, já em julho, em grandes nódoas pardo-escuras, a revelarem o alastramento vagaroso da seca. A planície ondeante, alargando-se no quadrante de NE até ao sopé da Canabrava, indefinida para o norte, batendo ao sul contra a Favela, empolava-se para o poente em maciços sucessivamente mais altos, subindo para as grimpas longínquas do Cambaio. O Vaza-Barris, cortado em gânglios esparsos, percorria-a em dobras divagantes. Numa destas, depois de correr direito para o ocidente, torce abruptamente ao sul e volve, transcorridos poucas centenas de metros, para leste, invertendo de todo o sentido da corrente e formando imperfeita península, tendo no extremo o arraial. Assim, bastava aos que o defendessem o estenderem-se ligando os dois galhos paralelos e próximos do rio, segundo a corda daquele círculo extensíssimo de circunvalação, para cortarem toda a frente do ataque. Porque a direção deste a interferia normalmente, como a flecha do enorme semicírculo: depois de transposta a baixada aquém de Trabubu, os assaltantes atravessariam a pés enxutos o Vaza-Barris e, volvendo mais uma vez, a última, à esquerda, carregariam de frente.
Antes de completa esta conversão, porém, o inimigo lhes renteou o passo. Eram sete horas da manhã.

Os exploradores receberam os primeiros tiros ao galgarem a barranca esquerda do rio. O terreno próximo empolava-se num cerro, onde se viam, revestindo-o até ao topo, lembrando muros de pedra seca derruídos, irregulares entrincheiramentos de pedras. $\mathrm{O}$ arraial, mil e quinhentos metros na frente, desaparecia numa depressão mais forte, lobrigando-se apenas, o olhar rasante pela crista dos cerros, os vértices das duas torres da igreja. Duas cruzes ameaçadoras e altas, recortando-se, nítidas, na claridade nascente...

A vanguarda atacada, uma companhia do $30^{\circ}$, replicou sem parar, acelerando o passo, ao tempo que o grosso da $1^{\text {a }}$ Brigada e quatro batalhões da $3^{\mathrm{a}}$ chegavam, compactos, abeirando-se do leito do rio, transpondo-o.

Toda a primeira coluna penetrava, reunida, a arena do combate.

\section{Linha de combate}

Os breves tropeços à translação dos dois Krupps tinham, em boa hora, remorado a retaguarda. De sorte que atenuando-se, em parte, o grave inconveniente de um acúmulo compressor de batalhões, o general Barbosa pôde tentar o esboço de uma linha de combate: a $1^{\mathrm{a}}$ Brigada distendendo-se em atiradores para a direita; a $3^{\text {a }}$, na mesma ordem, para a esquerda enquanto a ala de cavalaria, avantajando-se a toda brida a estremar o flanco direito, devia obstar que o envolvessem.

\section{Crítica}

Mas este movimento geral da tropa, como era de prever, foi mal feito. Sobre ser uma manobra sob o olhar do adversário, impropriava-a o terreno. Faltava-lhe a base física essencial à tática. A linha ideada, feita por um rápido desdobramento de brigadas numa longura de dois quilômetros, ia partir-se em planos verticais, segundo as cotas máximas dos cerros e o fundo das baixadas; e desde que não podia traçar-se com celeridade tal que tornasse o mais possível passageira uma situação de desequilíbrio e fraqueza, forçadamente assumida por todas as unidades combatentes, no se 
desarticularem e darem o flanco ao inimigo até nova posição de combate era impraticável.

Impraticável e perigosíssima. Diziam-no todas as condições palpáveis, concretas, em torno, da áspera topografia do solo ao extraordinário vigor de pronto patenteado pelo adversário, que tomara, desde os primeiros minutos, toda a frente à investida, numa fuzilaria impenetrável. E revelariam-no os resultados imediatos da ação. Os soldados - feixes de baionetas arremessando-se contra os morros - embatiam-lhes as ilhargas; tornejavam-nas, vingavam-nas a custo, no vertiginoso desatarse das linhas de atiradores. Mas tudo isto sem a firmeza e a velocidade que implicava a tática concebida. Além de não conseguirem executá-la deste modo, o que era essencial, alteraram-na logo em pormenores, insignificantes talvez, mas delatadores de um princípio de confusão nas fileiras. Em contraposição à ordem primitiva, a $3^{\text {a }}$ Brigada começou a lutar pelo flanco direito do $30^{\circ}$, que era da primeira. O $9^{\circ}$ Batalhão, na extrema esquerda, caíra no valo do Vaza-Barris por onde começou a avançar ferido de descargas irradiantes das duas bordas; enquanto o $25^{\circ}$, o $5^{\circ}$ e a ala direita do $7^{\circ}$ mal centralizavam o conflito.

\section{Confusão}

Era impossível estirar-se a formatura dispersa debaixo de balas em semelhante local. As seções, as companhias, os batalhões, destacando-se para a direita, única banda apropriada aos alinhamentos, enfiavam num labirinto de sangas em torcicolos e a breve trecho sentiam-se perdidos, desorientados, iludidos, sem verem o resto dos companheiros, sem poderem distinguir sequer os toques discordes das cornetas. Recuando, às vezes, no estonteamento da marcha tortuosa, supondo que avançavam, esbarravam, não raro, dados poucos passos, inopinadamente, com outras seções, outras companhias e outros batalhões, a marche-marche em sentido contrário...

Enredavam-se. O próprio general que os atirara em tais forças caudinas, mais tarde, na ordem do dia relativa ao feito, não encontrando no léxico opulento da nossa língua um termo lídimo para caracterizar bem a desordem da refrega, aventurou um gauchismo bárbaro — as forças entrelisavam-se...
De sorte que quando, passada meia hora, chegou a $2^{\mathrm{a}}$ coluna, era já sensível o número de baixas. Vinham mais duas brigadas, a $4^{\mathrm{a}}$ e a $5^{\mathrm{a}}$, ficando apenas de reserva, à reçaga, uma, a $6^{\mathrm{a}}$, sob as ordens imediatas do comando-em-chefe. Os recém-vindos deviam ainda alongar-se para a direita, segundo o plano único imposto pelas circunstâncias, o que, além de tomar toda a frente ao inimigo, obstando-lhe qualquer ação contornante, facultaria, depois, a investida final numa concentração contínua, que o próprio campo de combate indicava, definindo-se como setor amplíssimo de raios convergentes na praça das igrejas. Mas esta concepção tática, aliás rudimentar, não foi ainda efetuada. As brigadas auxilares, ao chegarem debaixo de uma fuzilaria estonteadora e deparando o tumulto, não podiam mais adaptar-se às linhas de um plano qualquer - articulando-se às que as tinham precedido, revigorando-as reforçando-lhes os pontos fracos, ou completando-lhes os movimentos; ou, ainda, prendendo-se-lhes às alas extremas, expandindo-lhas, ampliando-lhas de modo a estenderem, possante e vibrátil, defronte dos rudes antagonistas, a envergadura de ferro da batalha.

O coronel Carlos Teles em sua parte de combate - documento que não foi contestado - afirmou, depois, nuamente, que ao chegar notara não se acharem as forças nele engajadas com as formaturas que lhes são próprias.

Não obstante, o dever único na ocasião era avançar e carregar...

Avançaram e carregaram.

Eram oito horas da manhã. Formosa e quente manhã sertaneja que naquelas zonas irradia sempre um resplendor belíssimo de centelhas refluídas da terra desnuda e quartzosa... De sorte que se a tropa imprimisse naquele espadanar de brilhos o fulgor metálico de 3 mil baionetas, como se planeara, o cenário tornar-se-ia singularmente majestoso.

Mas foi lúgubre. Dez batalhões despencaram, de mistura, pelos cerros abaixo. Atulharam as baixadas. Galgaram depois as ladeiras que as apertam. Coalharam o topo das colinas; e desceram-nas de novo, ruidosamente, em tropel - para novamente investirem com as que se sucedem indefinidamente por toda a banda - num ondear de vagas humanas, revoltas, desencadeadas, estrepitosas, arrebatando nas encostas, 
espraiando-se nas planuras breves, acachoando um tumulto nos declives, represando-se comprimidas nas quebradas...

Os jagunços em roda fulminavam-nas, invisíveis, recuando talvez, talvez concentrando-se-lhes às ilhargas, talvez envolvendo-as...

Nada podia conjeturar-se. Os soldados começaram, certo, desde logo a conquistar bravamente o terreno. Vingavam morros sucessivos. Pisavam de momento em momento à borda de trincheiras, e no fundo destas os cartuchos detonados e ardentes delatavam-lhes a fuga recente do inimigo. Mas não sabiam no fim de algum tempo a direção real do próprio ataque que realizavam. A réplica dos adversários, por sua vez, variando em todos os rumos, parecia adrede disposta a desnorteá-los. Apenas no meio da ação ela se patenteou — uniforme e mais bem definida - na extrema direita, onde era lícito esperá-la tão constante, sugerindo o pensamento de algum vigoroso ataque de flanco que, se fosse impulsionado com energia, lançaria inevitavelmente os sertanejos, triunfantes, dentro dos batalhões desmantelados. Viu-se, porém, que aqueles realizavam apenas uma demonstração ligeira, deixando escapar a oportunidade para acometimento sério. Revelou-o o esquadrão de lanceiros num reconhecimento temerário. Precipitando-se velozmente naquela direção, deu de chofre, no tombar de uma encosta, com cerca de oitenta jagunços. Estavam dentro de um curral, de onde atiravam de soslaio sobre a tropa. Dispersou-os a pontaços de lança e a patas de cavalos, numa carga violenta. Subiu depois a galope, perseguindo-os, por uma ladeira menos abrupta, até ao alto de um dilatado platô, em rechã distendida para nordeste. E o arraial, a menos de trezentos metros, apareceu-lhe inopinadamente, na frente...

Neste comenos, por sua vez, ali chegavam atropeladamente alguns pelotões de infantaria.

\section{A situação era culminante.}

À fímbria das primeiras casas esparsas, num recosto fronteiro a cerca de trezentos metros das igrejas, oferecia-se aos combatentes área mais desimpedida e plana. Estes, porém, ali chegavam em grupos e sem ordem, mal repartidos na larga divisão das brigadas: a $5^{\mathrm{a}}$ marchando pela direita, a $3^{\mathrm{a}}$ e a $4^{\mathrm{a}}$ pelo centro e a $6^{\mathrm{a}}$, que entrara por último na refrega, pela esquerda, perlongando o rio.
Era o momento agudo do combate.

Naquela eminência, a tropa, sobretudo do centro para a direita, completamente exposta, estava dominada pelas igrejas e de nível com a parte alta do arraial, que se alteia para o norte. E deste último ponto até ao extremo da praça, a oeste - abrangendo todo o quadrante em longura mínima de dois quilômetros, caiu-lhe em cima, convergente, uma fuzilaria tremenda. As brigadas, entretanto, avançaram ainda. Mas incoerentemente, num dissipar improdutivo de valor e de balas, sem a retitude de um plano, sem uniformidade na marcha. No torvelinho das fileiras sobrevinham paralisações súbitas. Cada soldado tendo levado somente 150 cartuchos nas patronas gastara-os logo. De modo que se tornou necessária a parada de batalhões inteiros — em pleno conflito e na eminência completamente batida - para se abrir a machado os cunhetes de munições e distribuí-las.

Além disto, completando os tiroteios nutridos que irrompiam do arraial, onde cada parede se rachava em seteiras, atrevidos guerrilheiros afrontavam-se, de perto, com os assaltantes, alvejando-os à queima-roupa, abrindo-lhes, em descargas esparsas, claros assustadores. Batiam-nos ainda pelo flanco direito. O rarefeito dos estampidos denunciava, naquela banda, raros franco-atiradores. Mas estes, embora diminutos, tolhiam, pelo rigor das pontarias, o passo a pelotões inteiros.

\section{Di-lo episódio expressivo.}

\section{Tocaias dos jagunços}

Foi no último arranco da investida. A força, na ocasião fortalecida pela $4^{\text {a }}$ Brigada tendo à frente o coronel Carlos Teles, cujo estado-maior quase todo baqueara, abalara transpondo a última ladeira, quando as seções extremas daquele flanco, rudemente batidas, convergiam em acelerado para a direita, na repulsa a adversários que não viam, na planura desnuda e chata, que as vistas, entretanto, num lance devassavam. Arremeteram, ao acaso, na direção de um umbuzeiro, frondente ainda. Era a única árvore que ali aparecia. Os tiros rápidos, porém sucessivos como feitos por um homem único, bateram-nas, então de frente. Vararam-nas; desfalcaram-nas, derrubando, um a um, inflexivelmente, os que as formavam. Destes, muitos, por fim, estacaram atônitos pelo inconceptível de um fuzilamento em plaino escampo e limpo, onde não havia a ondulação mais ligeira acobertando o 
adversário inexorável. Outros, porém, teimaram, correndo para a árvore solitária. E a alguns passos dela, viram afinal, à borda de uma cova circular, ressurgir à flor do chão um rosto bronzeado e duro. E pulando do fojo, sem largar a arma, o jagunço, escorregando célere ao viés da encosta, desapareceu embaixo no afogado das grotas. Na trincheira soterrada trezentos e tantos cartuchos vazios diziam que o caçador feroz estivera largo tempo de tocaia naquela espera ardilosamente escolhida. Outras, idênticas, salpicando o solo, apareciam, salteadamente em roda. E em todas os mesmos restos de munições revelavam a estadia recente de um atirador. Eram como fogaças perigosas, alastrando-se por toda a banda. O chão explodia sob os pés da tropa. Os sertanejos desalojados desses esconderijos acolhiam-se, recuando, noutros; e as novas trincheiras arrebentavam logo em descargas vivas, até serem por sua vez abandonadas - concentrando-se pouco a pouco, aqueles, no arraial, cujas primeiras casas foram, ao cabo, atingidas às dez horas da manhã.

Arrumadas a leste, derramaram-se aquelas em lombada extensa, expandida mais ou menos segundo a meridiana e tendo a vertente ocidental suavemente descaída até à praça das igrejas, adiante. A força chegou àquela situação dominante cobrindo-a de uma linha descontínua e torcida, que se alongava para a esquerda até ao Vaza-Barris. Em parte os soldados abrigaram-se então nos casebres conquistados. A maioria, porém, impelida por oficiais, que na conjuntura se revelaram dignos de mais gloriosos feitos, avançou ainda, fulminada, num círculo de descargas, até aos fundos da igreja velha. A $6^{\text {a }}$ Brigada e o $5^{\circ}$ de Polícia, rompendo pelo álveo seco do rio, completaram esta acometida, que foi o derradeiro ímpeto da tropa.

Dali à frente ela não deu mais um passo. Conquistara um subúrbio diminuto da cidade bárbara e sentia-se impotente para ultimar a ação. As baixas avultaram. A retaguarda, coalhada de feridos e mortos, dava a impressão emocionante de uma derrota. Por entre eles passaram, contudo, ainda, impelidos a pulso, os dois Krupps. Postos logo depois em batalha, sobranceiros às igrejas, iniciaram um canhoneio firme - enquanto no alto da Favela, coroado de fumo, estrugiam dentro de uma cerração de tormenta as baterias do coronel Olímpio da Silveira. Mas, batido pelas granadas que ali tombavam, mergulhantes, batido pelas fuzilarias, que lhe tomavam toda a orla do nascente, o arraial recrudesceu na réplica. As balas irradiando de lá, inúmeras, varavam os tabiques das casas, em que se acolhiam os assaltantes, e matavam-nos lá dentro. A igreja nova, à margem do rio, fulminava a $6^{\text {a }}$ Brigada. $O 5^{\circ}$ de Polícia, rudemente combatido, caiu por fim numa grota estreita e coleante que o livrou de um fuzilamento em massa.

O Sol culminou nesta situação gravíssima e dúbia. A batalha iniciada a dois quilômetros continuava mais renhida na orla do casario.

Neste transe os chefes da $3^{\mathrm{a}}$ e $4^{\mathrm{a}}$ Brigadas, que se tinham avantajado até ao cemitério junto à igreja velha, reclamaram a presença do general Artur Oscar. Este apareceu depois de fazer a pé, mal encoberto pelas casinhas esparsas da vertente, uma travessia que foi um lance de bravura. Ao chegar encontrou, já gravemente feridos dentro do próprio pouso em que se haviam acolhido, o coronel Carlos Teles, o comandante do $5^{\circ}$ de linha e o capitão Antônio Sales. A conferência - rápida - realizou-se dentro do casebre exíguo. Em torno estalava a desordem: vibrações de tiros, tropear de carreiras doidas, notas estrídulas de cornetas, vozes precípites de comando, brados de cólera, gritos de dor, imprecações e gemidos. O tumulto.

Desorganizados os batalhões, cada um lutava pela vida. Nos grupos combatentes reunidos ao acaso, feitos de praças de todos os corpos, adensando-se por trás de frágeis paredes de taipa ou no cunhal das esquinas, batendo-se a todo transe, fizera-se uma seleção natural de valentes. Extintas todas as esperanças, o instinto animal da conservação, como sói sempre acontecer nesses epílogos sombrios dos combates, vestia a clâmide do heroísmo, desdobrando brutalmente a forma primitiva da coragem. Alheias ao destino dos outros companheiros, reduzindo a batalha à área estreita em que jogavam a vida, as frações combatentes atulhando os tijupares em cujas paredes, como os jagunços, rasgavam seteiras, negaceando nas esquinas, correndo desencontradamente pelos claros das vielas, com o adversário a dois passos, enleados quase em luta braço a braço, agiam, à toa, por conta própria. Famintos e agoniados de sede, ao penetrarem as pequenas vivendas, dentro das quais no primeiro minuto nada distinguiam, na penumbra dos cômodos estreitos e sem janelas, olvidavam o morador. Percorriam-nos, tateantes, em busca de uma moringa d'água ou um cabaz de farinha. E baqueavam, não raro, por um disparo à queima-roupa. Soldados possantes, que vinham resfolegando de uma luta de quatro horas, caíram, alguns mortos por mulheres frágeis. Algumas valiam homens. Velhas megeras de tez baça, faces murchas, olhares afuzilando faúlhas, cabelos 
corredios e soltos, arremetiam com os invasores num delírio de fúrias. E quando se dobravam, sob o pulso daqueles, juguladas e quase estranguladas pelas mãos potentes, arrastadas pelos cabelos, atiradas ao chão e calcadas pelo tacão dos coturnos - não fraqueavam, morriam num estertor de feras, cuspindo-lhes em cima um esconjuro doloroso e trágico...

\section{Nova vitória desastrosa}

No meio desta confusão desastrosa, o comandante-em-chefe resolveu que se guardasse a posição conquistada. O alvitre impunha-se por si, inflexivelmente. Mais uma vez no fim de uma arremetida violenta a expedição se via adstrita a estacar, encravando-se em situação insolúvel. Eram por igual impossíveis — o avançamento e o recuo.

Imobilizou-se ao cair da tarde numa ourela estreita do arraial — uma quinta parte deste, limitando-o pelo levante — na larga coxilha expandida de norte a sul e descendo em declive para a praça. As casas que ali se erigiam, menos unidas que as demais, tinham data recente. Canudos, no seu crescimento surpreendedor, desbordara da depressão, em que se formara, para o viso das colinas envolventes.

A tropa ocupara um desses subúrbios. A cidadela propriamente dita, com a sua feição original e bárbara, não fora a bem dizer atingida. Ali estava, perto, em frente — ameaçadoramente —, sem muros, mas inexpugnável, pondo diante da invasão milhares de portas, milhares de entradas abertas para a rede inextricável dos becos tortuosos.

Mas não se podia ultrapassar o esforço temerário feito. A linha avançada dos corpos que mais se tinham adiantado firmou-se definitivamente. Numa grota profunda, que drenava os flancos da Favela, na extrema esquerda, entrincheirou-se o $5^{\circ}$ de Polícia, distendendo-se até à borda direita do Vaza-Barris, onde se ligava ao $26^{\circ}$ de Infantaria. Este, por sua vez, desdobrando-se, ia unir-se na margem oposta ao $5^{\circ}$ de linha, junto ao cemitério. Seguiam-se sucessivamente: o $25^{\circ}$, nos fundos da igreja velha; o $7^{\circ}$, paralelamente à face oriental da praça; e depois o $25^{\circ}$, o $40^{\circ}$ e o $30^{\circ}$ entranhando-se num dédalo de casebres, para o norte. Inflectindo deste ponto à retaguarda, a linha, com as forças desenvolvidas do $12^{\circ}, 31^{\circ}$ e $38^{\circ}$, encurvava-se, convexa, afastando-se do casario e guardando o flanco direito do acampamento, onde ficou o quartel-general, na vertente oposta, protegido pelos $14^{\circ}, 32^{\circ}, 33^{\circ}$ e $34^{\circ}$ Batalhões e pela ala de cavalaria.

O resto do dia, e grande parte da noite, empregaram-no na construção dos entrincheiramentos, blindando-se de tábuas ou pedras as paredes das casas, ou escolhendo-se raros pontos menos enfiados pelos projetis. Estes trabalhos impunham os máximos resguardos. Os expedicionários entalavam-se numa ilharga do arraial e o inimigo vigiava-os, implacável. Afrouxara a fuzilaria, mas para recair na praxe costumeira das tocaias: em cada frestão de parede insinuava-se um cano de espingarda e um olhar indagador. Cada passo do soldado fora do ângulo de uma esquina era a morte.

Começou-se a sentir o império de uma situação mais incômoda que a anterior, da Favela. Ali havia, ao menos, a esperança do assalto e da vitória; desprezava-se ainda o adversário, que só revidava de longe, entre ciladas. Agora, nem este engano restava. O jagunço ali estava - indomável desafiando um choque braço a braço. Não o atemorizara a proximidade dos contendores, profissionais da guerra, que lhe enviavam as gentes das terras grandes. Eles estavam-lhe, agora, ao lado, a dois passos, acotovelando-o, acolhidos sob os mesmos tetos de taipa e aumentando, de repente, em poucos minutos, de 3 mil almas, a população do lugarejo sagrado. Mas não lhe haviam modificado sequer o primitivo regime. Ao empardecer do dia, o sino da igreja velha batia, calmamente, a Ave-Maria; e, logo depois, do seio amplíssimo da outra, ressudava o salmear merencório das rezas...

Toda a agitação do dia fora como incidente vulgar e esperado.

\section{Baixas}

No entanto, a expedição atravessara violentíssima crise. Tivera cerca de mil homens, 947, entre mortos e feridos, e estes, com os caídos nos recontros anteriores, reduziam-na consideravelmente. Impressionavam-na, ademais, os resultados imediatos do acometimento. Três comandantes de brigadas, Carlos Teles, Serra Martins e Antonino Néri, que viera à tarde com a $7^{\mathrm{a}}$, estavam fora de combate. Numa escala ascendente, avultavam baixas de oficiais menos graduados e praças. Alferes e tenentes haviam, com desassombro incrível, malbaratado a vida em toda a linha. De alguns citavam-se, depois, os arrojados lances: Cunha Lima, estudante da Escola 
Militar de Porto Alegre, que, ferido em pleno peito numa carga de lanceiros, concentrara os últimos alentos no último arremesso da lança caindo, em cheio, sobre o inimigo, feito um dardo; Wanderley, que, precipitando-se a galope pela encosta aspérrima da última colina, fora abatido ao mesmo tempo que o cavalo no topo da escarpa, rolando por ela abaixo em queda prodigiosa, de titã fulminado; e outros, baqueando todos, valentemente - entre vivas retumbantes à República - , haviam dado à refrega um traço singular de heroicidade antiga, revivendo o desprendimento doentio dos místicos lidadores da média idade. O paralelo é perfeito. Há nas sociedades retrocessos atávicos notáveis; e entre nós os dias revoltos da República tinham imprimido, sobretudo na mocidade militar, um lirismo patriótico que lhe desequilibrara todo o estado emocional, desvairando-a e arrebatando-a em idealizações de iluminados. A luta pela República, e contra os seus imaginários inimigos, era uma cruzada. Os modernos templários, se não envergavam a armadura debaixo do hábito e não levavam a cruz aberta nos copos da espada, combatiam com a mesma fé inamolgável. Os que daquele modo se abatiam à entrada de Canudos tinham todos, sem excetuar um único, colgada ao peito esquerdo em medalhas de bronze, a efígie do marechal Floriano Peixoto e, morrendo, saudavam a sua memória - com o mesmo entusiasmo delirante, com a mesma dedicação incoercível e com a mesma aberração fanática com que os jagunços bradavam pelo Bom Jesus misericordioso e milagroso...

Ora, esse entusiasmo febril, à parte as precipitações desastrosas decorrentes, no dia 18 de julho foi a salvação...

Uma tropa exclusivamente robustecida pela disciplina, que se desorganizasse daquela maneira, estaria perdida. Mas os soldados rudes, em cujo ânimo combalido penetravam desalentos e incertezas, imobilizaram-se sob o hipnotismo da coragem pessoal dos chefes, ou dominados pelo prestígio de oficiais que, gravemente feridos, alguns mal sustendo a espada, avançavam em cambaleios para as linhas de fogo - moribundos e desafiando a morte.

Ficaram de algum modo sitiados entre eles e os jagunços.

\section{Nos flancos de Canudos}

A noite de 18 de julho, contra a expectativa geral, passou em relativa calma. Os sertanejos, por sua vez, claudicavam. No ânimo do chefe expedicionário pairara o temor de um assalto noturno para o qual não havia reação possível. As frágeis linhas de defesa, ainda quando não fossem rotas por qualquer dos seus pontos, podiam ser envolvidas pelos lados e, postas entre dois fogos e contidas na frente pelo arraial impenetrável, seriam facilmente destruídas. A situação, porém, resolvera-se pela inércia dos adversários. No dia subsequente uma linha de bandeirolas vermelhas, feita de cobertores reúnos, demarcava um segmento de cerco diminutíssimo: um quinto da periferia enorme do arraial. Mal o fechava pelo levante. Nesta banda mesmo estava em claro a extrema direita; do mesmo modo que à esquerda, entre as vertentes da Favela, e os primeiros sulcos do arroio da Providência, onde jazia o corpo policial, se via largo espaço livre. Para se ultimar a circunferência fazia-se mister um traçado que, prolongando-se para a direita em cheio ao norte, inflectindo depois para oeste, ladeando o rio e acompanhando-o na sua curvatura para o sul, galgando as ondulações maiores do solo no primeiro socalco das serras do Calumbi e do Cambaio, volvesse finalmente a leste pelo esporão dos Pelados. Um circuito de seis quilômetros, aproximadamente. Ora, a expedição reduzida a pouco mais de 3 mil homens válidos, centenares dos quais se removiam à guarda da Favela, não poderia ajustar-se a tão ampla cercadura, mesmo que tha permitisse o adversário. A paralisação temporária das operações impunhase inevitável, resumindo-se na defesa da posição ocupada, até que maiores reforços facultassem novos esforços.

\section{Posição crítica}

O general Artur Oscar avaliou, então, com segurança, o estado das coisas. Pediu um corpo auxiliar de 5 mil homens e curou de dispositivos para garantir a força que triunfara de maneira singular, a pique de uma derrota. Estava, depois de mais um triunfo, na conjuntura torturante de não poder arriscar nem um passo à frente, nem um passo atrás. Oficialmente, as ordens do dia decretavam o começo do sítio. Mas, de fato, como sempre sucedera desde 27 de junho, a expedição é que estava sitiada. Tolhia-a 0 arraial a oeste. Ao sul os altos da Favela fechavam-se-lhe atravancados de 
feridos e doentes. Para o norte e o nascente se desenrolava o deserto impenetrável. A área da sua ação aparentemente aumentara. Dois acampamentos distintos pareciam denotar mais larga movimentação, liberta da constrição de trincheiras envolventes. Esta ilusão, porém, extinguiu-se no próprio dia do assalto. Os cerros, varridos a cargas de baionetas poucas horas antes, figuravam-se de novo guarnecidos. As comunicações com a Favela tornaram-se logo dificílimas. Tombavam, novamente baleados, os feridos que para lá se arrastavam; e um médico, o Dr. Tolentino, que na tarde do combate dali descera, caíra, gravemente ferido, na ribanceira do rio. A travessia no campo conquistado fez-se problema sério aos conquistadores. Por outro lado os que haviam invadido o breve trecho do arraial copiavam, linha a linha, a reclusão que antes observavam nos jagunços. Como estes, apinhavam-se nos casebres ardentes como fornos, ao reverberar dos meios-dias mormacentos e jaziam horas esquecidas, olhos enfiados pelas rachas das paredes, caindo escandalosamente na mesma guerrilha de tocaias, sondando com as vistas o casario e disparando as espingardas todas a um tempo — cem, duzentos, trezentos tiros! — contra um vulto, um trapo qualquer, percebido de relance, indistinto e fugitivo, ao longe, no torvelinho dos becos.

Distribuída a última ração — um litro de farinha para sete praças e um boi para um batalhão —, restos do comboio salvador, era-lhes impossível preparar convenientemente a refeição escassa. Um fio de fumo branqueando no teto de barro da choupana era um chamariz de balas! À noite um fósforo aceso punha fogo a rastilhos de descargas.

Os jagunços sabiam que podiam fulminar dentro dos casebres frágeis anteparos da argila — os moradores intrusos. O coronel Antonino Nery fora ferido, justamente quando, depois de atravessar com a sua brigada a zona perigosa e aberta do combate, se acolhera a um deles. Casamataram-nos, então. Espessaram-lhes as paredes com muros interiores, de pedras, ou revestiram-nas de tábuas. E assim mais garantidos, atravessando grande parte do dia, de bruços, sobre os jiraus, olhares rasantes pelos esvãos do colmo, dedos enclavinhados nos fechos da espingarda — os vitoriosos cheios de sustos tocaiavam os vencidos...

Sobre o quartel-general, centralizado pela barraca do comandanteem-chefe, na vertente oposta, os projetis passavam inofensivos, repelidos pelo ângulo morto da colina. E aquele teve durante todo o correr da noite, que lhe fechara a jornada trabalhosa, passando-lhe em sibilos ásperos sobre a tenda, os respingos dos tiroteios que se renhiam do outro lado com as linhas avançadas. Os comandantes destas, tenentes-coronéis Tupi Caldas e Dantas Barreto, destemerosos ambos, sentiam-se todavia na iminência de um desastre, compreendendo "que um passo à retaguarda em qualquer ponto da linha central lhes seria a perdição total”" . Porque esta preocupação de uma catástrofe próxima, iniludível, ninguém a ocultava. Deduziam-se irresistivelmente na sequência de anteriores sucessos. Impunha-se. Durante muitos dias dominou todos os espíritos.

Um inimigo habituado à luta regular que soubesse tirar partido de nossas desvantagens táticas não teria certamente deixado passar esse momento em que a vingança e a desforra teriam a consequência da mais requintada selvageria.

Mas o jagunço não era afeito à luta regular. Fora até demasia de frase caracterizá-lo inimigo, termo extemporâneo, esquisito eufemismo suplantando o "bandido famigerado" da literatura marcial das ordens do dia. O sertanejo defendia o lar invadido, nada mais. Enquanto os que lho ameaçavam permaneciam distantes, rodeava-os de ciladas que lhes tolhessem o passo. Mas, quando eles, ao cabo, lhe bateram às portas e arrombaram-lhas a coices de armas, aventou-se-lhe, como único expediente, a resistência a pé firme, afrontando-os face a face, adstrito à preocupação digna da defesa e ao nobre compromisso da desforra. Canudos só seria conquistado casa por casa. Toda a expedição iria despender três meses para a travessia de cem metros, que a separavam da abside da igreja nova. E no último dia de sua resistência inconcebível, como bem poucas idênticas na História, os seus últimos defensores, três ou quatro anônimos, três ou quatro magros titãs famintos e andrajosos, iriam queimar os últimos cartuchos em cima de 6 mil homens!

Aquela pertinácia formidável começou no dia 18 e não fraqueou mais. Terminara o ataque mas a batalha continuou, interminável, monótona, aterradora, com a mesma intercadência espelhada na Favela: difundida em tiros que sulcavam o espaço de minuto a minuto, ou tiroteios alastrando-se furiosamente por todas as linhas, em arrancos súbitos, repentinos combates de quartos de hora, prestes travados, prestes desfeitos, antes que

\footnotetext{
${ }^{1}$ Coronel Dantas Barreto, Última expedição a Canudos.
} 
terminassem as notas emocionantes dos alarmas. Esses assaltos subitâneos, intermeados de longas horas de repouso relativo, traduziam sempre uma inversão de papéis. Os assaltantes eram, por via de regra, os assaltados. O inimigo encantoado é quem lhes marcava o momento angustioso das refregas, e estas surgiam sempre de chofre.

Noite velha, às vezes, quebrando um armistício de minutos, que os soldados da vanguarda aproveitavam para descanso ilusório, cabeceando abraçados às carabinas, um foguetão ascendia rechiando asperamente, feito um rasgão no firmamento escuro. E à sua luz fugaz viam-se as cimalhas das igrejas debruadas de uma orla negra e fervilhante. O combate feria-se na treva, aos fulgores intermitentes das fuzilarias.

Outras vezes, contra o que era de esperar, era ao romper do dia, em plena manhã esplendorosa e ardente, que os jagunços acometiam desassombradamente, às claras.

\section{Notas de um diário}

Um diário minucioso da luta naqueles primeiros dias, lhe patenteia o caráter anormalmente bárbaro. Esbocemo-lo em traços largos até ao dia 24 de julho, apenas para definir uma situação que daquela data em diante não se transmudou.

Dia 19 - A fuzilaria inimiga principia às cinco horas da manhã. Prossegue durante o dia. Entra pela noite dentro. O comandante da $1^{\text {a }}$ coluna, para revigorar a repulsa, determina a vinda de mais dois canhões Krupps, que estavam na retaguarda, a fim de serem assestados à noite. Às doze e meia foi ferido, em seu acampamento, dentro de um casebre onde descansava, numa rede, o comandante da $7^{\text {a }}$ Brigada. Às duas horas da tarde, depois de apontar e disparar o canhão da direita para uma das torres da igreja nova, morre trespassado por uma bala o tenente Tomás Braga. À tarde descem com dificuldade da Favela algumas reses para alimento da tropa. A boiada dispersa-se, fustigada a tiros, ao atravessar o Vaza-Barris, sendo a custo reunida, perdendo-se algumas cabeças. Ao toque de recolher os jagunços investem contra as linhas, perdurando o ataque até às nove $e$ meia e continuando, afrouxo, daí por diante. Resultado: um comandante superior ferido; um subalterno morto, dez ou doze praças fora de combate.
Dia 20 - O acampamento é subitamente atacado quando as cornetas de todos os corpos tocam a alvorada. Tiroteios durante o dia todo. Consegue-se assestar apenas um dos canhões reconduzidos. Há o mesmo número de baixas da véspera; um soldado morto.

Dia 21 - Madrugada tranquila. Poucos ataques durante o dia. Os canhões da Favela bombardeiam até à boca da noite. Dia relativamente calmo. Poucas baixas.

Dia 22 - Sem aguardar a iniciativa do adversário, a artilharia abre o canhoneio às cinco horas da manhã — provocando revide pronto e virulento de atiradores encobertos nos muros das igrejas. São penosamente conduzidos, do campo da ação para o acampamento da Favela, os últimos feridos. Segue em reconhecimento pelas cercanias o tenente-coronel Siqueira de Meneses. Ao voltar declara estar o inimigo muito forte, e que muito poucas casas de Canudos estão em nosso poder, atenta a comparação com o número das que formam o povoado. Somente à noite se torna possível distribuir parcas rações de gêneros aos soldados da linha de frente, o que foi impossível fazer durante o dia, pela vigilância dos antagonistas. Às nove horas da noite assalto violento pelos dois flancos. Resultado: 25 homens fora de combate.

Dia 23 - Alvorada tranquila. Repentinamente, uma hora depois, às seis da manhã, os jagunços, depois de um movimento contornante despercebido, caem impetuosamente sobre a retaguarda do campo de batalha. São repelidos pelo $34^{\circ}$ Batalhão e Corpo Policial, deixando quinze mortos, uma cabocla prisioneira e um surrão de farinha. À noite tiroteios cerrados. Os três canhões deram apenas nove disparos por falta de munições.

Dia 24 - Começou o bombardeio ao levantar do Sol. O povoado, contra o costume, suporta-o sem réplica. Os shrapnels da Favela caem lá dentro e estouram, como se batessem numa tapera deserta. Durante largo tempo trucida-o o canhoneio impunemente. Às oito horas, porém, ouvem-se alguns estampidos, raros, à direita; e logo depois são assaltados os canhões daquele flanco. Enreda-se o conflito braço a braço, carabinas abocadas aos peitos, e generaliza-se num crescendo apavorante. Vibram de ponta a ponta dezenas de cornetas. Toda a tropa forma para a batalha. O ataque visava cortar a retaguarda da linha de frente. Um movimento temerário. Cortando- 
a cairiam sobre o quartel-general, e poriam os sitiantes entre dois fogos. Era um plano de Pajeú que, tendo deposto os demais cabecilhas, assumira a direção da luta. Esse assalto durou meia hora. Os jagunços repelidos, porém, volveram minutos depois, outra vez sobre a tropa, arremetendo com maior arrojo sobre a direita. A custo repelidos recuam até às primeiras casas não conquistadas de onde reatam o tiroteio, cerrado, contínuo. Tombam o comandante do $33^{\circ}$, Antônio Nunes Sales, e muitos oficiais e praças. Ao meio-dia cessa a agitação.

Súbito silêncio desce sobre os dois campos. À uma hora - novo assalto, mais impetuoso ainda. Formam-se todos os batalhões. Era como a oscilação de um aríete. A nova pancada percutiu, insistente, nas linhas do flanco direito. O impetuoso Pajeú baqueia mortalmente ferido. Tombam do nosso lado muitos combatentes entre os quais, morto, o tenente Figueira, de Taubaté; feridos o comandante do $33^{\circ}$, capitão Joaquim Pereira Lobo e muitos oficiais. A fim de distrair o inimigo, o comandante-em-chefe determina que atirem os corpos do flanco esquerdo, ainda não investidos. A força toda descarrega as armas contra o arraial. Segue em acelerado uma metralhadora para reforçar a direita.

Atroam no alto todas as baterias da Favela...

Repele-se ao inimigo. À noite tirotear constante até a madrugada.

No dia 25... Nesse dia, como nos outros, as mesmas cenas, pouco destoantes, imprimindo na campanha uma monotonia dolorosa. Os entrincheiramentos da linha de cerco faziam-se nesse intermitir de combates; e somente à noite podia ser distribuída a refeição insuficiente aos soldados famintos ou conseguiam estes, ajoujados de cantis e marmitas, arriscar a tentativa heroica de alguns passos até às cacimbas do VazaBarris, buscando a água que lhes mitigasse a sede longamente suportada. Iam-se assim os dias...

\section{Triunfos pelo telégrafo}

Estes fatos chegaram às capitais da República e dos Estados inteiramente baralhados.

Do exposto pode bem inferir-se que era isto inevitável.
Quando os próprios lidadores mal rastreavam, na discordância dos sucessos, um juízo qualquer sobre a própria situação, é natural que os que atentavam, de longe, para o drama imerso na profundura dos sertões, desandassem em conjeturas, sobre instáveis, falsas. Falou-se a princípio na vitória. A travessia do Cocorobó, anteriormente sabida, pressagiava que o exército houvesse abatido, de um salto, os rebeldes. Notícias esparsas provindas do campo de ação, ou telegramas incisivos, marcavam além disto, à luta, um desenlace em três dias.

Volvidos, porém, quinze, patenteou-se a inanidade de esforços dos que haviam entrado do capricho de fantasiar triunfos. Viu-se que os jagunços haviam mais uma vez vingado o círculo cortante das baionetas. De sorte que enquanto a expedição se exauria no ermo da Favela e ia tombar, exaurida por uma sangria profunda, num trecho de Canudos - a opinião nacional, pela imprensa, extravagava, balanceando as mais aventurosas hipóteses que ainda saltaram dos prelos.

O espantalho da restauração monárquica negrejava, de novo, no horizonte político atroado de tormentas. A despeito das ordens do dia em que se cantava vitória, os sertanejos apareciam como os chouans depois de Fontenay.

Olhava-se para a História através de uma ocular invertida: o bronco Pajéu emergia com o facies dominador de Chatelineau. João Abade era um Charrete de chapéu de couro.

Depois do dia 18 a ansiedade geral cresceu. A notícia do acontecimento, como a dos anteriores, principiando num entoar de vitórias, descambava depois, a pouco e pouco, recortando-se de lancinantes dúvidas, até quase à convicção de uma derrota. Chegavam, todavia, da zona das operações, telegramas paradoxais e deploravelmente extravagantes.

\section{Calcavam-se numa norma única:}

Bandidos encurralados! Vítória certa! Dentro de dois dias estará em nosso poder a cidadela de Canudos! Fanáticos visivelmente abatidos!

Mais verídicos, porém, começaram desde o dia 27 de julho a seguir para o litoral, demandando a capital da Bahia — os documentos vivos da catástrofe... 


\section{Capítulo VI}

\section{Pelas estradas. Os feridos}

A remoção dos doentes e feridos para Monte Santo era urgente.

Assim, partiram logo as primeiras turmas protegidas por praças de infantaria até ao extremo sul da zona perigosa, Juá.

Começou, então, a derivar lastimavelmente pelos caminhos o refluxo da campanha. Golfava-o o morro da Favela. Diariamente, em sucessivas levas, abalaram dali, em inúmeros bandos, todos os desfalecidos e todos os inúteis, em redes de caroá ou jiraus de paus roliços os enfermos mais graves, outros cavalgando penosamente cavalos imprestáveis e regues, ou apinhados em carroças ronceiras. A grande maioria, a pé.

Saíam quase sem recursos, combalidos, exaustos de provações, afundando, resignados, na região ermada pela guerra.

Era a entrada do estio. O sertão principiava a mostrar um facies melancólico, de deserto. Sugadas dos sóis as árvores dobravam-se murchas, despindo-se dia a dia das folhas e das flores; e, alastrando-se pelo solo, os restolhos pardo-escuros das gramíneas murchas refletiam já a ação latente do incêndio surdo das secas. A luz crua e viva dos dias claríssimos e cálidos descia, deslumbrante e implacável, dos céus sem nuvens, sem transições apreciáveis, sem auroras e sem crepúsculos, irrompendo, de chofre, nas manhãs doiradas, apagando-se repentinamente na noite, requeimando a terra. Deprimia-se o nível das cacimbas. Esgotavam-se os regatos efêmeros, de leitos lastrados de seixos, onde tênues fios de águas defluíam imperceptíveis como nos uedes africanos; e, na atmosfera adurente, no chão gretado e poento, pressentia-se a invasão periódica do regime desértico sobre aquelas paragens infelizes.

O clima extremava-se em variações enormes: os dias repontavam queimosos, as noites sobrevinham frigidíssimas.

As marchas só podiam realizar-se às primeiras horas da manhã e ao descer das tardes. Mal culminava o Sol era forçoso interrompê-las: todo o seu ardor parecia varar, intacto, o ambiente puríssimo e, refluído pelo solo mal protegido por vegetação rarefeita, aumentar de intensidade. Ao mesmo tempo, dispersos, refletindo em todas as dobras do terreno, os seus raios rebrilhavam, ofuscantes, nos visos das serranias; e pelos ares irrespiráveis e quentes passavam como que fulgurações de queimadas extensas alastrandose pelos tabuleiros. Assim, a partir das dez horas da manhã, estacionavam as caravanas nos lugares menos impróprios ao descanso, à beira dos cursos d'água ganglionados em poças esparsas, onde a umidade remanente alentava a folhagem das caraíbas e baraúnas altas; junto aos tanques ainda cheios, perto dos sítios em abandono; ou em falta destes, à fímbria das ipueiras rasas salpicando pequenas várzeas sombreadas pelas ramagens virentes dos icozeiros.

\section{Acampavam.}

Neste mesmo dia, ao entardecer, mal refeitas as forças, reatavam a rota, progredindo, sem ordem, na medida do vigor de cada um. Saindo unidas da Favela, as turmas a pouco e pouco se distendiam pelos caminhos, fragmentando-se em pequenos grupos; esparsas, afinal, em caminhantes solitários.

Os mais fortes ou mais bem montados avantajavam-se rápidos cortando escoteiros para Monte Santo, alheios ao companheiros retardatários. Acompanhavam-nos logo, conduzidos em redes aos ombros de soldados possantes, os oficiais feridos. A grande maioria não os encalçava; seguia vagarosamente, dissolvendo-se pelos caminhos. Alguns, quando os demais abalavam dos pousos transitórios, se deixavam ficar, quietos, à sombra dos arbustos murchos, de todo sucumbidos de fadigas enquanto outros, aguilhoados pela sede, mal extinta nas águas impuras das almácegas sertanejas e impelidos pela fome, torcendo o rumo, batiam afanosamente os desvios multívios das caatingas, apelando para os recursos da flora singular transbordante de frutos e de espinhos - e desgarravam, desarraigando tubérculos de umbuzeiros, sugando os cladódios túmidos dos cardos espinescentes, catando os últimos frutos das árvores desfolhadas.

Deslembravam-se do inimigo. A ferocidade do jagunço era balanceada pela selvatiqueza da terra.

Ao fim de poucos dias a tortuosa vereda do Rosário encheu-se de foragidos. Ali estava a mesma trilha que um mês antes haviam percorrido, impávidos ante quaisquer recontros com o adversário esquivo, fascinados 
pelo irradiar de 4 mil baionetas, sacudidas no ritmo febricitante das cargas. Parecia-lhes agora mais áspera e impraticável - coleando em curvas sucessivas, tombando em ladeiras resvalantes, empinando-se em cerros, tornejando encostas, insinuando-se impacta, entre montanhas.

E reviam-lhe, pasmos, os trechos memoráveis.

Nas cercanias de Umburanas, o casebre destruído, onde os sertanejos, de tocaia, tinham aferrado de um choque o grande comboio da expedição Artur Oscar; além das Baixas, as margens do caminho debruando-se de ossadas brancas, adrede dispostas numa encenação cruel - recordavam o morticínio de março; numa inflexão antes do Angico, o ponto em que Salomão da Rocha alteara, por minutos, diante da onda rugidora que vinha em cima da coluna Moreira César, a barragem de aço de suas divisões de artilharia; no córrego seco, mais longe, a ribanceira a pique em que tombara do cavalo, pesadamente, morto, o coronel Tamarindo; nas proximidades do Aracati e Juetê, choupanas em ruínas, esteios e traves roídos dos incêndios, cercas arrombadas e invadidas de mato, velhas roças em abandono, estereografando, indelével, o rastro das expedições anteriores...

Perto do Rancho do Vigário, por um requinte de lúgubre ironia, os jagunços cobriram de floração fantástica a flora tolhiça e decídua: dos galhos tortos dos angicos pendiam restos de divisas vermelhas, trapos de dólmãs azuis e brancos, molambos de calças carmesins ou negras, e pedaços de mantas rubras - como se a ramaria morta desabotoasse toda em flores sanguinolentas...

Em torno, sem variantes no aspecto entristecedor, a mesma natureza bárbara. Morros enterroados, formas evanescentes de montanhas roídas pelos aguaceiros fortes e repentinos, tendo às ilhargas, à mostra, a romper, a ossatura íntima da terra repontando em apófises rígidas, ou desarticulandose em blocos amontoados, em que há traços violentos de cataclismos; plainos desnudos e chatos feitos llanos desmedidos; e, por toda a parte, mal reagindo à atrofia no fundo das baixadas úmidas, uma vegetação agonizante e raquítica, espalhada num baralhamento de ramos retorcidos - reptantes pelo chão, contorcendo-se nos ares num bracejar de torturas...

Choupanas paupérrimas, portas abertas para o caminho, surgiam em vários trechos, ainda não descolmadas, mas vazias, porque as deixara o vaqueiro que a guerra espavorira ou o fanático que indireitara para Canudos.

Eram logo tumultuariamente invadidas, ao tempo que as deixavam outros hóspedes surpreendidos: raposas ariscas e medrosas, saltando das janelas e esvãos da cobertura — olhos em chamas e pelo arrepiado - e atufando-se, aos pinchos, nas macegas; ou centenares de morcegos, esvoaçando desequilibradamente dos cômoros escuros, tontos, rechiantes.

A estância desolada animava-se por algumas horas. Armavam-se redes pelos quartos exíguos, na saleta sem soalho e fora, nos troncos das árvores do terreiro; amarravam-se os muares nas estacas cruzadas do curral deserto; estendiam-se pelas cercas frangalhos de capotes, cobertores e fardas velhas. Grupos erradios circuitavam a vivenda esquadrinhando, curiosos, a horta maltratada, de canteiros invadidos pelas palmatórias de flores rutilantes; e um ressoar quase festivo, de vozes, relembrava, um instante, a quadra feliz em que os matutos ali passavam a vida nas horas aligeiradas pela paz dos sertões. Os mais fortes enveredavam logo para a cacimba pouco distante onde, indiferentes aos retardatários e esquecidos dos que viriam depois e por muitas semanas ou meses ainda fariam a mesma escala obrigatória, se banhavam, lavavam os cavalos suados e poentos e abluíam as chagas no líquido que só se renova de ano em ano, pelas chuvas, passageiras. Volviam com os cantis e marmitas cheios, avaramente sobraçados.

Não raro, alguns bois — rebotalhos de manadas grandes tresmalhadas pelo alvoroto da guerra - ao lobrigarem, de longe, a azáfama que movimentava de novo a paragem a que se haviam aquerenciado, o rancho tranquilo onde tinham sofrido a primeira ferra, para lá abalavam velozmente. Vinham urrando, numa alegria ruidosa e forte. Buscavam o vaqueiro amigo que os campeara outrora e iria, de novo ao som das cantigas conhecidas ou ao toar tristonho do aboiado, levá-lo às soltas prediletas, aos logradouros fartos e às aguadas frescas.

Irrompiam, troteando, no terreiro...

E tinham recepção cruel. A turba faminta circulava-os em tumulto numa assonância de gritos discordantes. Estrondavam as espingardas. Avivados todos os corpos combalidos, arremetiam em monteria doida com os animais surpresos e refluindo logo, estonteadamente, embolados, para a 
trama do matagal bravio. Depois de se afadigarem em correrias exaustivas, irritando nos espinhos as chagas recém-abertas e agravando a febre, matavam afinal um, dois, três bois no máximo, em tiroteios vivos, que lembravam combates. Carneavam. E quedavam-se, após esses incidentes providenciais, fartos, quase felizes pelo contraste da própria penúria, aguardando o amanhecer para reatarem o êxodo...

Então, naquela quietude breve, salteava-os uma idéia empolgante um assalto dos jagunços! Viam-se inermes, depauperados, andrajosos e repulsivos quase, lívidos de fome, varridos para o deserto como trambolhos inúteis - e tinham temores infantis. O adversário, que se afoitara com as brigadas aguerridas e levara os assomos cegos ao ponto de ferrar canhões a pulso, trucidá-los-ia em minutos. E a noite descia cheia de ameças...

Valentes endurados no regime bruto das batalhas tinham sobressaltos de pavor ante as coisas mais vulgares e velavam, cautos, a despeito das fadigas, armando os ouvidos aos rumores vagos e longínquos das chapadas.

Torturavam-nos alucinações cruéis. A deiscência das vagens das caatingueiras, abrindo-se com estalidos secos e fortes, soava-lhes feito percussão de gatilhos ou estalos de espoletas, dando a ilusão de súbitas descargas de alguma algara noturna repentina; e as grinaldas fosforescentes das cunanãs irradiavam, ao longe, esbatidas nas sombras, como restos de fogueiras, em torno às quais velassem, em silêncio, expectantes, tocaias inumerosas...

A manhã libertava-os. Deixavam a paragem assombradora. Lá ficavam, porém, às vezes, rigidamente quietos, pelos cantos, os companheiros que a morte libertara. Não os enterravam. Escasseava o tempo. O chão duro, de grés, despedaçaria os alviões, opondo-lhes consistência de pedra. Alguns, depois dos primeiros passos, fraqueavam de vez. Deixavam-se ficar exaustos, pelas curvas do caminho. Ninguém lhes dava pela falta. Desapareciam, eternamente esquecidos, agonizando no absoluto abandono. Morriam. E dias, semanas e meses sucessivos, os viandantes, passando, viam-nos na mesma postura: estendidos à sombra mosqueda de brilhos das ramagens secas, o braço direito arqueando-se à fronte, como se a resguardasse do sol, com a aparência exata de combatentes fatigados, descansando. Não se decompunham. A atmosfera ressequida e ardente conservava-lhes os corpos. Murchavam apenas, refegando a pele, e permaneciam longo tempo à margem dos caminhos múmias aterradoras revestidas de fardas andrajosas...

Por fim, não impressionavam. Quem se aventura nos estios quentes à travessia dos sertões do Norte afeiçoa-se a quadros singulares. A terra, despindo-se de toda a umidade - numa intercadência de dias adustivos e noites quase frias - ao derivar para o ciclo das secas parece cair em vida latente, imobilizando apenas, sem o decompor, os seres que sobre elas vivem. Realiza, em alta escala, o fato fisiológico de uma existência virtual, imperceptível e surda - energias encadeadas, adormecidas apenas, prestes a rebentarem todas, de chofre, à volta das condições exteriores favoráveis, originando ressurreições improvisas e surpreendedoras. E como as árvores recrestadas e nuas que, à vinda das primeiras chuvas, se cobrem, exuberando seiva, de flores, sem esperar pelas folhas, transmudando em poucos dias aqueles desertos em prados - as aves que tombam mortas dos ares estagnados, a fauna resistente das caatingas que se aniquila, e o homem que sucumbe à insolação fulminante, parecem, jazendo largo tempo intactos, sem que os vermes lhes alterem os tecidos, esperar também pela volta das quadras benfazejas. Por ali ficam, patenteando, por vezes, singulares aparências de vida: as suçuaranas - que não puderam vingar, demandando outras paragens, o círculo incandescente das secas contorcidas, garras fincadas no chão, como em saltos paralisados; e - à beira das cacimbas extintas — o pescoço alongado, procurando um líquido que não existe, os magros bois, mortos há três meses ou mais, caídos sobre as pernas ressequidas, agrupando-se em manadas imóveis...

Os primeiros aguaceiros varrem, de pronto, esses espantalhos sinistros. A decomposição é, então, vertiginosa, como se os devorassem flamas vorazes. É a sucção formidável da terra, arrebatando-lhes, ávida, todos os princípios elementares, para a revivescência triunfal da flora.

Os foragidos avançavam considerando, de relance, aqueles cenários lúgubres. Empolgara-os de todo o pensamento exclusivo do abandono, no menor tempo possível, do sertão maninho e bruto. O terror e a imagem da própria miséria venciam, por fim, a sobrecarga muscular das caminhadas feitas. Galvanizavam-nos; lançavam-nos desesperadamente pela estrada desmedida em fora... 
Seguiam sem que entre eles se rastreassem breves laivos sequer de organização militar. Tendo, na maior parte, por adaptação, copiado os hábitos do sertanejo, nem os distinguia o uniforme desbotado e em tiras. E calçando alpercatas duras; vestindo camisas de algodão; sem bonés ou barretinas, cobertos de chapéus de couro, figuravam famílias de retirantes demandando em atropelo o litoral, fustigados pela seca.

Algumas mulheres, amantes de soldados, vivandeiras-bruxas, de rosto escaveirado e envelhecido, completavam a ilusão.

Oficiais ilustres, o general Savaget, os coronéis Teles e Nery e outros, volvendo feridos ou enfermos, passavam pelo meio desses bandos envoltos numa indiferença doentia. Não recebiam continência. Eram companheiros menos infelizes, nada mais. Passavam, desapareciam céleres, adiante, levantando ondas de pó. E recebiam pelas costas olhares ameaçadores, em que afuzilavam mal sopitados desapontamentos dos que lhes invejavam os cavalos ligeiros.

Os mais ditosos alcançavam por fim, depois de quatro dias de marcha, na trifurcação das estradas do Rosário, Monte Santo e Calumbi, o sítio de Juá, outra casinha de taipas no recosto de uma lomba, pela qual descai o terreno sombreado de juazeiros altos, tendo na frente os sem-fins das chapadas. Julgavam-se salvos. Mais um dia de jornada levava-os ao Caldeirão Grande, a melhor fazenda daqueles lugares, vivenda quase senhoril, ereta sobre um cerro largo, tendo ao sopé as águas de um riacho represadas em açude farto. Aí num raio de poucos quilômetros a natureza é outra. Transfigura-se, movimentando-se em serranias pequenas orladas de vegetação mais viva, e os caminhantes forravam-se, durante algumas horas, à obsessão acabrunhadora dos plainos estéreis e das serras devastadas.

Estavam à entrada do que se chamava — “a base de operações” da campanha.

Ao outro dia prosseguiam para Monte Santo. E, depois de duas horas de caminho, reanimava-os o aspecto da pequena vila, percebida à distância de uma légua. Repontava ridente no ondear dos tabuleiros amplos casinhas reunidas derramando-se por um socalco suavemente inclinado às plantas da montanha abrupta, em cujo vértice a capela branca, arremessada na altura, destacando-se nítida, a projetar-se no firmamento azul, parecia enviar-lhes, de longe, um aceno carinhoso e amigo.
Ao alcançarem-na, porém, volviam as desesperanças. Era ainda o deserto. O vilarejo morto, vazio, desprovido de tudo, mal os abrigava por um dia. Havia-o deixado a população, caindo na caatinga, consoante o dizer dos matutos, fugindo, amedrontada, por igual do jagunço e do soldado. Uma guarnição exígua tomara conta da praça humílima e lá atravessava, inútil, os dias, numa mandria mais insuportável que as marchas e as batalhas. Fantasiara-se em casarão acaçapado e escuro um hospital militar. Mas este era o pavor e a condenação suprema de todos os feridos e doentes. De sorte que o vilarejo, com as suas vielas tortas, condecoradas de nomes sonoros — rua Moreira César! rua Capitão Salomão! — era uma agravante na região ingrata; era o deserto metido entre paredes e afogado na trama de alguns becos imundos, cheios de detritos e da farragem repugnante dos batalhões que ali tinham acampado, mais deplorável que o deserto franco purificado pelos sóis e varrido pelos ventos.

Os caminhantes ao chegarem, fugindo à parceria incômoda dos morcegos nas casas em abandono, acampavam na única praça quadrangular e grande, disputando a sombra do velho tamarineiro, ao lado do barracão da feira. No outro dia, cedo, cada um por sua conta, largava para Queimadas, renovando a travessia. Eram mais dezesseis léguas extenuantes, mais seis ou oito dias de amarguras, sob o cautério dos mormaços crestadores, adstritos a escalas inevitáveis à borda das cacimbas, por Quirinquinquá duas vivendas tristes, circuitadas de mandacarus silentes, erectas sobre larga bossa de granito exposto; pelo Cansanção, lugarejo minúsculo — uma dúzia de casas cingidas de ipueiras - , pela Serra Branca, lembrando uma rancharia de tropeiros, de aspecto festivo, ensombrada de ouricurizeiros apendoados; pelo Jacurici; por todas as lagoas de águas esverdinhadas e suspeitas...

\section{Depredações}

E aquele caminho, então povoado, ermou-se. Os bandos revoltos rompiam-no espalhando estragos, como se foram restos de uma caravana de bárbaros claudicantes. Doentes e feridos, em magotes ameaçadores, de onde transudavam alaridos, imprecações e frases arrepiadoras de angústias e revoltas irrefreáveis, abeiravam-se das choupanas, apelando para a hospitalidade incondicional dos tabaréus. Fizeram a princípio pedidos coléricos, mais irritantes que intimações. Depois o assalto franco. Repruía- 
lhes o ânimo, escandalizando-lhes a vida tormentosa, o quadro tranquilo daqueles lares pobres, onde deriva, quieta, a existência dos matutos. E varejavam-nos - impulsivamente, numa irreprimível hipnose de destruição - fazendo saltar as portas a coices d'armas, enquanto a família sertaneja, apavorada, fugia para os recessos das macegas.

\section{Incêndios}

Depois - era preciso uma diversão qualquer estupidamente dramática que lhes distraísse um momento as agonias fundas! - tomando de tições em fogo chegavam-nos aos colmos de sapê. Irrompiam as flamas, num deflagrar instantâneo. Passavam os haustos rijos do nordeste e esparziam as fagulhas pela caatinga seca. Em breve, céleres arrebatadas pelo vento, enoveladas em rolos de fumo cindidos de labaredas, rolando pelas quebradas e transpondo-as, circulando todas as encostas, avassalando o topo dos morros, repentinamente acesos num relampaguear de crateras súbitas, crepitavam as queimadas, inextinguíveis, derramando-se por muitas léguas em roda.

Os foragidos, já agora salvos, suportavam os últimos transes do êxodo penosíssimo requintando nas tropelias, ampliando o círculo de ruínas da guerra e iam-se de abalada para o litoral - ao mesmo tempo miserandos e maus, inspirando a piedade e o ódio — rudemente vitimados, brutalmente vitimando. Chegavam a Queimadas esparsos e exaustos, alguns quase moribundos. Atulhavam os trens da estrada de ferro e desciam para a Bahia.

\section{Primeiras notícias certas}

Aguardava-os uma curiosidade ansiosa.

Iam chegar, afinal, as primeiras vítimas da luta que empolgara a atenção do país inteiro. A multidão desbordando da estação terminal da linha férrea, na Calçada, derramando-se pelas ruas próximas até ao forte de Jequitaia, contemplava diariamente a passagem do heroísmo infeliz. E nunca lhe imaginou aspectos tão dramáticos.

Sacudiam-na frêmitos de emoções nunca sentidas.
Os feridos chegavam em estado miserando. Prolongavam pelas ruas da cidade aquela onda repulsiva de trapos e carcaças, que vinham rolando pelas veredas sertanejas o refluxo repugnante da campanha.

Era um desfilar cruel. Oficiais e soldados, uniformizados pela miséria, vinham indistintos, revestidos do mesmo fardamento inclassificável: calças em fiapos, mal os reguardando como tangas; camisas estraçoadas; farrapos de dólmãs sobre os ombros; farrapos de capotes, em tiras, escorridos pelos torsos desfibrados, dando ao conjunto um traço de miséria trágica. Coxeando, arrastando-se penosamente, em cambaleios, titubeantes e imprestáveis, traziam no escavado das faces e na atitude dobrada um traço comovente da campanha. Esta desvendava pela primeira vez sua feição real, naqueles corpos combalidos, varados de balas e de espinhos, retalhados de golpes. E chegavam às centenas todos os dias: a 6 de agosto, 216 praças e 26 oficiais; a 8, 150; a 11, 400; a 12, 260; a 14, 270; a 18, 53; e assim por diante.

A população da capital recebia-os comovida. Como sempre sucede, o sentimento coletivo ampliara as impressões individuais. O grande número de pessoas, identificadas pela mesma comoção, fez-se o expoente do sentir de cada um e, vibrando uníssonas todas as almas, presas do mesmo contágio, e sugestionadas pelas mesmas imagens, todas as individualidades se apagaram no anonimato nobilitador da multidão piedosa que bem poucas vezes apareceu tão digna na História. A vasta cidade fez-se um grande lar. Organizaram-se em toda a linha comissões patrióticas, para agenciar donativos, que espontaneamente surgiram numerosos, constantes. No Arsenal de Guerra, na Faculdade Médica, nos hospitais, nos próprios conventos, se improvisaram enfermarias. Em cada uma dessas os gloriosos mutilados foram postos sob o patrocínio de algum nome ilustre: Esmarch, Claude Bernard, Duplay, Pasteur, jamais tiveram tão bela consagração no futuro.

Avantajando-se à ação do governo, o povo constituíra-se tutor natural dos enfermos, amparando-os incondicionalmente, abrindo-lhes os lares, rodeando-os, animando-os, auxiliando-lhes os passos trôpegos nas ruas. Nos dias facultados às visitas, invadia os hospitais, em massa, em silêncio - religiosamente. Abeiravam-se então os visitantes dos leitos como se neles jazessem velhos conhecidos; tratavam com os doentes menos graves sobre as provações sofridas e lances arriscados ocorridos; e, ao deixarem 
aquelas trágicas exposições da guerra feitas de traumatismos e moléstias horríveis, levavam, afinal, um juízo claro sobre a luta mais brutal dos nossos tempos. Mas, por um contraste inexplicável, sobre esta comiseração profunda e geral pairava, intenso, um entusiasmo vibrante. Os mártires tinham ovações de triunfadores. E estas despontavam ao acaso, sem combinações prévias, rápidas, espontâneas, incisivas, aparecendo e desaparecendo em quartos de hora, num desencadear intermitente de movimentos impulsivos. Os dias sucediam-se agitados numa larga movimentação de multidões ruidosas, turbilhonando nas ruas e nas praças, no meio de expansões discordes, numa alacridade singular rorejada de prantos, por meio da qual se fazia a comemoração sombria do heroísmo. Os feridos eram uma revelação dolorosíssima, certo, mas de algum modo alentadora. Naquelas sevícias retratava-se a energia de uma raça. Aqueles homens que chegavam dilacerados pelas garras do jagunço e pelos espinhos da terra eram o vigor de um povo posto à prova do ferro, à prova do fogo e à prova da fome. Abaladas pelo cataclismo da guerra, as camadas superficiais de uma nacionalidade cindiam-se, pondo à luz os seus elementos profundos naqueles titãs resignados e estoicos. Sobre tudo isto um pensamento diverso, não boquejado sequer mas por igual dominador, latente em todos os espíritos: a admiração pela ousadia dos sertanejos incultos, homens da mesma raça, de encontro aos quais se despedaçavam daquele modo batalhões inteiros...

E um longo frêmito tonificador vibrava nas almas. Faziam-se romarias ao quartel da Palma, onde estava ferido o coronel Carlos Teles; à Jequitaia, onde convalescia o general Savaget; e quando este último pode arriscar alguns passos nas ruas, paralisou-se inteiramente toda a azáfama comercial da Cidade Baixa, em ovação espontânea e imensa, que, irradiando de repente e congregando a população em torno do heroico chefe da $2^{a}$ coluna, transmudou um dia comum de trabalho em dia de festa nacional.

\section{Baixas}

Sobre esta agitação chegavam diuturnamente pormenores que a acirravam. Sabia-se, por fim, positivamente, com rigor aritmético, a extensão do desastre. Era surpreendente.
De 25 de junho, em que trocara os primeiros tiros com o inimigo, até 10 de agosto, tivera a expedição 2.049 baixas.

Detalhavam-nas os mapas oficiais.

No total entrava a $1^{\text {a }}$ coluna com 1.171 homens e a $2^{\text {a }}$ com 878 . Discriminadamente eram estes os algarismos:

$1^{\text {a }}$ coluna - Artilharia: 9 oficiais e 47 praças feridas; 2 oficiais e 12 praças mortas; Ala de Cavalaria: 4 oficiais e 46 praças feridas; 30 oficiais e 16 praças mortas; engenheiros: 1 oficial e 8 praças feridas; 1 praça morta; Corpos de Polícia: 8 oficiais e 46 praças feridas; 8 oficiais e 24 praças mortas; $5^{\circ}$ Batalhão de Infantaria: 4 oficiais e 66 praças feridas; 1 oficial e 25 praças mortas; $7^{\circ}: 8$ oficiais e 95 praças feridas; 5 oficiais e 52 praças mortas; $9^{\circ}$ : 6 oficiais e 59 praças feridas; 2 oficiais e 22 praças mortas; $14^{\circ}: 8$ oficiais e 119 praças feridas; 5 oficiais e 42 praças mortas; $15^{\circ}: 5$ oficiais e 30 praças feridas; 10 praças mortas; $16^{\circ}$ : 5 oficiais e 24 praças feridas; 10 praças mortas; 25: 9 oficiais e 134 praças feridas; 3 oficiais e 55 praças mortas; $27^{\circ}: 6$ oficiais e 45 praças feridas; 24 praças mortas; $30^{\circ}$ : 10 oficiais e 120 praças feridas; 4 oficiais e 35 praças mortas.

$2^{\mathrm{a}}$ coluna -1 general ferido; Artilharia: 1 oficial morto; $12^{\circ}$ de Infantaria: 6 oficiais e 128 praças feridas; 1 oficial e 50 praças mortas; $26^{\circ}: 6$ oficiais e 36 praças feridas; 2 oficiais e 22 praças mortas; $31^{\circ}: 7$ oficiais e 99 praças feridas; 4 oficiais e 48 praças mortas; $32^{\circ}: 6$ oficiais e 62 praças feridas; 4 oficiais e 31 praças mortas; $32^{\circ}: 10$ oficiais e 65 praças feridas; 1 oficial e 15 praças mortas; $34^{\circ}: 4$ oficiais e 18 praças feridas; 7 praças mortas; $35^{\circ}: 4$ oficiais e 91 praças feridas; 1 oficial e 22 praças mortas; $40^{\circ}: 9$ oficiais e 75 praças feridas; 2 oficiais e 30 praças mortas.

E a hecatombe progredia com uma média diária de oito homens fora de combate. Por outro lado, os adversários pareciam dispor de extraordinários recursos.

\section{Versões e lendas}

Transfiguravam-nos, além disto, numa distensão exagerada, as imaginações superexcitadas. Recente mensagem do Senado Federal, onde batera também a onda da comoção geral, tendo requerido, esteada em veementes denúncias, esclarecimentos sobre o terem sido despachadas em 
Buenos Aires com destino aos portos de Santos e Bahia armas, que tudo delatava se destinarem aos conselheiristas, tal incidente, em que incidiam todas as fantasias, assumiu, ampliado pela nevrose comum, visos de realidade.

Completavam-no, justificando e do mesmo passo refletindo o modo de pensar das repúblicas americanas, todas as notícias transmitidas pelos seus órgãos mais sérios. O de mais peso talvez na América do Sul ${ }^{1}$, depois de se referir aos curiosos sucessos da campanha, aditava-lhes pormenores de um simbolismo estranho e pavoroso:

Trata-se de duas missivas que, com intervalo de dois dias recebemos da "Sección Buenos-Aires de la unión internacional de los amigos del imperio del Brasil” comunicando-nos, por ordem da seção executiva em Nova York, que a referida União tem ainda uma reserva de não menos 15 mil homens - só no Estado da Bahia para reforçar em caso de necessidade o exército de fanáticos; além de 100 mil em vários Estados do Norte do Brasil e mais 67 mil em certos pontos dos Estados Unidos da América do Norte, prontos a sair em qualquer momento para as costas do ex-Império, todos muito bem armados e preparados para a guerra. Também temos, ajuntam as missivas, armas dos mais modernos sistemas, munições e dinheiro em abundância.

De uma redação, caligrafia e ortografia corretas, estas enigmáticas comunicações trazem à sua frente a mesma inscrição que as subscreve, escrita com tinta que faz recordar a violácea cor dos mortos, destacando-se as maiúsculas em vermelho, da vermelha cor do sangue.

Ante o quadro formidável de homens e armas que nos oferecem os misteriosos amigos do Império, de forma não menos misteriosa, não sabemos se pensar em uma daquelas terríveis associações que forjam nas trevas seus planos de destruição ou em alguns cavalheiros dados à mistificação do próximo.

Entretanto, pelo que possa haver no fundo de tudo isto, é que fazemos constar e acusamos recebimento das repetidas missivas.

Acreditava-se. A quarta expedição ilhara-se de todo, no território conflagrado, a pique de uma catástrofe. Diziam-no insuspeitos informes. Só

\footnotetext{
${ }^{1}$ La Nación, de Buenos Aires, 30 de julho.
}

do município de Itapicuru, garantia-se, haviam partido 3 mil fanáticos para Canudos, conduzidos por um padre que, aberrando dos princípios ortodoxos, lá se ia comungar das tolices abstrusas do cismático. Pela Barroca passavam centenares de quadrilheiros armados, seguindo o mesmo rumo. Citavam-se nomes de novos cabecilhas. Apelidos funambulescos, como o dos chouans: Pedro, o Invisível, José Gamo, Caco de Ouro, e outros.

Agravando estas conjeturas vinham notícias verdadeiras. Os sertanejos dispartiam pelo sertão em algaras atrevidas: atacaram o termo de Mirandela, guiados por Antônio Fogueteiro; investiram, tomaram e saquearam a Vila de Santana do Brejo; irradiavam para toda a banda. Alargavam o âmbito da campanha, revelando mesmo lineamentos firmes de estratégia segura. Além do arraial duas novas posições de primeira ordem e defensáveis estavam guarnecidas: as vertentes caóticas do Caipã e as cordas de cerros em torno da Várzea da Ema. Desbordando de Canudos, a insurreição espraiava-se desta maneira pelos lados de um triângulo enorme, em que podiam inscrever-se 50 mil baionetas. Alastrava-se.

Os comboios que partiam de Monte Santo, ainda que reforçados, não por batalhões mas por brigadas, tinham viagem acidentada, tolhida de constantes assaltos. Atingido o Aracati, era indispensável que viessem de Canudos dois ou três batalhões a protegê-los. O sinistro trecho de estrada entre o rancho do Vigário e as Baixas, tornara-se o pavor dos mais provados valentes. Era o lugar clássico do estouro das boiadas e da dispersão dos cargueiros, espantados pelos tiroteios vivos e atropelando pelotões inteiros no recuar precípite da fuga.

E nesses recontros sucessivos, adrede feitos à pertubação das marchas, começara-se a lobrigar, por fim, uma variante do jagunço, auxiliando-o, indiretamente, com outros intuitos. Distinguiam-se entre os claros das galhadas rarefeitas, passando, céleres, no vertiginoso pervagar das guerrilhas, brilhos de botões de fardas, loivos rubros de calças carmesins...

O desertor faminto atacava os antigos companheiros.

Era um lastimável sintoma, completando com um outro caráter a campanha, cuja feição dia a dia se agravava num episodear extremado dos sucessos mais triviais. 
Os soldados enfermos, em perene contato com o povo, que os conversava, tinham-se, ademais, constituído rudes cronistas dos acontecimentos e confirmavam-nos mercê da forma imaginosa por que a própria ingenuidade lhes ditava os casos, verídicos na essência, mas deformados de exageros, que narravam. Urdiam-se estranhos episódios. O jagunço começou a aparecer como um ente à parte, teratológico e monstruoso, meio homem e meio trasgo; violando as leis biológicas, no estadear resistências inconceptíveis; arrojando-se, nunca visto, intangível, sobre o adversário; deslizando, invisível, pela caatinga, como as cobras; resvalando ou tombando pelos despenhadeiros fundos, como espectro; mais leve que a espingarda que arrastava; e magro, seco, fantástico, diluindo-se em duende, pesando menos que uma criança, tendo a pele bronzeada colada sobre os ossos, áspera como a epiderme das múmias...

A imaginação popular, daí por diante, delirava na ebriez dos casos estupendos, apontoados de fantasias.

Alguns eram rápidos, espelhando incisivamente a energia inamoldável daqueles caçadores de exércitos.

\section{"Viva o Bom Jesus !"}

Numa das refregas subsequentes ao assalto, ficara prisioneiro um curiboca ainda moço que a todas as perguntas respondia automaticamente, com indiferença altiva:

\section{"Sei não!”}

Perguntaram-lhe por fim como queria morrer.

"De tiro!"

“Pois há de ser a faca!” contraveio, terrivelmente, o soldado.

Assim foi. E; quando o ferro embotado lhe rangia nas cartilagens da glote, a primeira onda de sangue borbulhou, escamando, à passagem do último grito gargarejando na boca ensanguentada:

"Viva o Bom Jesus!..."

\section{Um lance épico}

Outros tinham delineamentos épicos:

No dia $1^{\circ}$ de julho, o filho mais velho de Joaquim Macambira, rapaz de dezoito anos, abeirou-se do ardiloso cabecilha:

"Pai! quero escangalhar a matadeira!”

O astuto guerrilheiro, espécie grosseira de Imanus, acobreado e bronco, encarou-o impassível :

“Consulta o Conselheiro - e vai."

O valente abalou, seguido de onze companheiros dispostos. Transpuseram o Vaza-Barris, cortado em cacimbas. Investiram com a larga encosta ondulante da Favela. Embrenharam-se, num deslizar flexuoso de cobras, pelas caatingas ralas.

Ia em meio o dia. O Sol irradiava a pino sobre a terra, jorrando sem fazer sombras, até ao fundo dos grotões mais fundos, os raios verticais e ardentes...

Naquelas paragens o meio-dia é mais silencioso e lúgubre que a meia-noite. Transverberando nas rochas expostas, refletindo nas chapadas nuas, repelido pelo solo recrestado e duro, todo o calor emitido para a terra reflui, tresdobrado, para o espaço, nas colunas ascensionais dos ares irrespiráveis e candentes. A natureza queda-se, enervada em quietude absoluta. Não sopra a viração mais leve. Não bate uma asa nos ares, cuja transparência junto ao chão se perturba em ondulações rápidas e ferventes. Repousa, estivando, a fauna das caatingas. Pendem, murchos, os ramos das árvores estonadas.

O exército descansava no alto da montanha, abatido pela canícula. Deitados a esmo pelas encostas, bonés caídos sobre o rosto para os resguardar, dormitando ou pensando nos lares distantes, as praças aproveitavam alguns momentos de tréguas, refazendo forças para a afanosa lide. Em frente, derramado sobre colinas - minúsculas casinhas em desordem, sem ruas e sem praças, acervo incoerente de casebres — aparecia Canudos, deserto e mudo, como uma tapera antiga.

Todo o exército repousava... 
Nisto despontam, cautos, emergindo à ourela do matagal rasteiro e

\section{Capítulo VII} trançado, de arbúsculos em esgalhos, na clareira, no alto, onde estaciona a artilharia, doze rostos inquietos, olhares felinos, rápidos, percorrendo todos os pontos. Doze rostos apenas de homens ainda jacentes, de rastro, nos tufos das bromélias. Surgem lentamente. Ninguém os vê; ninguém os pode ver. Dão-lhes as costas com indiferença soberana vinte batalhões tranquilos. Adiante divisam a presa cobiçada. Como um animal fantástico, prestes a um bote repentino, o canhão Whitworth, a matadeira, empina-se no reparo sólido. Volta para Belo Monte a boca truculenta e rugidora que tantas granadas revessou já sobre as igrejas sacrossantas. Caem-lhe sobre o dorso luzidio e negro os raios do sol, ajaezando-a de lampejos. Os fanáticos contemplam-na algum tempo. Aprumam-se depois à borda da clareira. Arrojam-se sobre o monstro. Assaltam-no; aferram-no; jugulam-no. Um traz uma alavanca rígida. Ergue-a num gesto ameaçador e rápido...

E a pancada bate, estrídula e alta, retinindo...

E um brado de alarma estala na mudez universal das coisas; multiplica-se nas quebradas; enche o espaço todo; e detona em ecos que atroando os vales, ressaltam pelos morros numa vibração triunfal e estrugidora, sacudindo num repelão violento o acampamento inteiro...

Formaram-se em acelerado as divisões. Num segundo os assaltantes se vêem num círculo de espingardas e sabres, sob uma irradiação de golpes e de tiros. Um apenas se salva - chamuscado, baleado, golpeado correndo, saltando, rolando, impalpável entre os soldados tontos, varando redes de balas, transpondo cercas dilaceradoras de baionetas, caindo em cheio nas macegas, rompendo-as vertiginosamente e despenhando-se, livre afinal, alcandorado sobre abismos, pelos pendores abruptos da montanha...

Estes e outros casos - exagerado romancear dos mais triviais sucessos - dando à campanha um tom impressionante e lendário, abalavam a opinião pública da velha capital e por fim a de todo o país...

\section{Outros reforços}

Era urgente uma intervenção mais enérgica do governo. Impunhamna, do mesmo passo, as apreensões crescentes, as últimas peripécias da luta e a própria insciência sobre o curso real das operações. As opiniões como sempre disparatavam, discordes. Para a maioria os rebeldes contavam com elementos sérios. Era evidente. Não se compreendia que batidos em todas as ordens do dia - heroicamente escritas - eles, tendo ainda franca a fuga para os sertões de S. Francisco, onde não havia descobri-los, esperassem, pertinazes, no arraial, que se lhes fechassem, pelo complemento do assédio, as derradeiras saídas. Deduziam-se, lógicos, corolários graves. À parte a hipótese do sobre-humano devotamento, fazendo-os sucumbir em massa sob os escombros dos templos consagrados, imaginavam-se-lhes traças guerreiras formidáveis embaralhando de todo a estratégia regular. O número, que se dizia diminuto, dos que permaneciam em Canudos arrostando tudo, era, certo, um engodo armado a arrastar para ali exclusivamente o exército e iludi-lo em combates estéreis, até que se congregassem, noutros lugares, fortes contingentes para o assalto final, por toda a banda, sobre os sitiantes, pondo-os entre dois fogos.

Contravinham, porém, juízes mais animadores. O coronel Carlos Teles, em carta dirigida à imprensa, afirmou de maneira clara o número reduzido de jagunços - duzentos homens válidos, talvez sem recursos nenhuns — , abastecidos e aparelhados apenas do que haviam tomado às anteriores expedições. O otimismo, de fato exageradíssimo, do valente, porém, afogou-se na incredulidade geral. Aniilavam-no todos os fatos e sobretudo aquelas irrupções diárias de feridos, abalando num crescendo a comoção nacional.

\section{A Brigada Girard}

Sobrevieram outros por igual desastrosos. Atendendo aos primeiros reclamos do general Artur Oscar, o governo tinha prontamente organizado uma brigada auxiliar que, ao revés das demais, não entrava na luta distinta por um número seco e inexpressivo. Tinha, segundo louvável praxe, sem 
curso entre nós, mercê da qual se amplia sobre os comandados a glória do comandante, um nome — Brigada Girard.

Dirigia-a o general Miguel Maria Girard e formavam-na três corpos, saídos da guarnição da Capital Federal: o $22^{\circ}$, do coronel Bento Tomás Gonçalves, o $24^{\circ}$, do tenente Rafael Tobias, e o $38^{\circ}$, do coronel Filomeno José da Cunha. Eram 1.042 praças e 68 oficiais, perfeitamente armados e levando para a luta insaciável o repasto esplêndido de 850 mil cartuchos Mauser.

Mas, por um conjunto de circunstâncias, que fora longo miudear, ao invés de auxiliar esta tropa tornou-se um agente debilitante. Abalou do Rio de Janeiro comandada pelo chefe que lhe dera o nome e foi com ele até Queimadas, onde se reuniu a 31 de julho. Partiu de Queimadas a 3 de agosto, dirigida por um coronel, até Monte Santo. Largou de Monte Santo para Canudos, a 10 de agosto, sob o comando de um major. Deixara na Bahia um coronel e alguns oficiais - doentes. Deixara em Queimadas um general, um tenente-coronel e mais alguns oficiais - doentes. Deixara em Monte Santo um coronel e mais alguns oficiais — doentes...

\section{Heroísmo estranho}

Decompunha-se pelas estradas. Partiam-lhe do seio pedidos de reforma mais alarmantes do que aniquilamentos de brigadas. Salteara-a um beribéri excepcional exigindo não já a perícia de provectos médicos senão o exame de psicólogos argutos. Porque afinal o medo teve ali os seus grandes heróis, revelando a coragem estupenda de dizer a um país inteiro que eram covardes.

Ao endireitar de Queimadas para o sertão aquela força encontrara as primeiras turmas de feridos e fora sulcada pelo assombro da guerra. Passaram-lhe pelo meio do acampamento, em Contendas, o general Savaget, o coronel Nery, o major Cunha Matos, o capitão Chachá Pereira e outros oficiais. Recebeu-os ainda entusiasticamente: oficiais e praças enfileirados às margens do caminho, saudando-os. Mas depois amorteceuse-lhe o fervor. Apenas com três dias de viagem, começou de sofrer privações, vendo diminuídos os víveres que levava e repartia com as sucessivas turmas de feridos encontrados, chegando exausta e esmorecida a Monte Santo.

\section{Em viagem para Canudos}

Tomou para Canudos onde era ansiosamente esperada, a 10 de agosto, despida inteiramente do esplêndido aparato hierárquico com que nascera. Dirigia-a o fiscal do $24^{\circ}$, Henrique de Magalhães, estando os corpos comandados pelo major Lídio Porto e capitães Afonso de Oliveira e Tito Escobar. A marcha foi difícil e morosa. Desde Queimadas lutava-se com dificuldades sérias de transporte. Os cargueiros, animais imprestáveis, velhos e cansados, muares refugados das carroças da Bahia e tropeiros improvisados - rengueavam, tropeçando pelos caminhos, imobilizando os batalhões, e remorando a avançada.

Chegou desse modo a Aracati, onde lhe foi entregue um comboio que devia guarnecer até Canudos.

Neste comenos dizimava-a a varíola. Destacavam-se das suas fileiras, diariamente, dois ou três enfermos, volvendo para o hospital, em Monte Santo. Outros, estropiados, naquela repentina transição das ruas calçadas da Capital Federal para aquelas ásperas veredas, distanciavam-se, perdidos à retaguarda, confundindo-se com os feridos, que vinham em direção oposta.

De sorte que ao passar em Juetê, no dia 14 de agosto, lhe foi providencial o encontro com o $15^{\circ}$ Batalhão de Infantaria, já endurado na luta, e que viera de Canudos. Porque no dia seguinte, depois de decampar das Baixas, onde parara na véspera para aguardar a vinda de grande número de praças retardatárias, foi no Rancho do Vigário violentamente atacada. Os jagunços aferraram-na de flanco, pela direita, do alto de um cerro dominante, e quase de frente, de uma trincheira marginal. Abrangeram-na toda uma descarga única. Tombaram mortos na guarda da frente um alferes do $24^{\circ}$ e, na extrema retaguarda, outro, do $38^{\circ}$. Baquearam algumas praças nas fileiras intermédias. Alguns pelotões se embaralharam estonteadamente surpresos, bisonhos ainda ante os guerrilheiros ferozes. A maioria disparou desesperadamente as armas. Estrugiram cornetas, vozes trêmulas, altas, entrecortadas, desencontradas, de comando. Dispararam, espavoridos, os cargueiros. A boiada estourou, mergulhando na caatinga...

O $15^{\circ}$ Batalhão tomando a vanguarda guiou os lutadores vacilantes. Não se repeliu o inimigo. A retaguarda ao passar pelo mesmo ponto foi, por sua vez, alvejada. 
Depois deste revés, porque o foi, bastando dizer-se que de 102 bois que comboiava restaram apenas onze, foi a brigada novamente investida no Angico. Deu uma carga de baionetas platônica em que não perdeu um soldado, entrando afinal em Canudos, onde os enrijados campeadores, que ali estavam sob a disciplina tirânica dos tiroteios diuturnos, a acolheram com a denominação de Mimosa, nome, que, entretanto, mais tarde, os bravos oficiais fizeram que se apagasse, a exemplo do primeiro título.

\section{Capítulo VIII}

\section{Novos reforços}

Este ataque chegou à Bahia com as proporções de batalha perdida, pondo mais um solavanco no desequilíbrio geral, mais uma dúzia de boatos no turbilhonar das conjecturas; e o governo começou a agir com a presteza requerida pela situação. Reconhecida a ineficácia dos reforços recémenviados, cuidou de formar uma nova divisão, arrebanhando os últimos batalhões dispersos pelos Estados, capazes de mobilização rápida. E, para pulsear de perto a crise, resolveu enviar para a base de operações um de seus membros, o Secretário de Estado dos Negócios da Guerra, marechal Carlos Machado de Bittencourt.

Este seguiu em agosto para a Bahia, ao tempo que de todos os ângulos do país abalavam novos lutadores. O movimento armado repentinamente se generalizava, assumindo a forma de um levantamento em massa.

As tropas confluíam do extremo norte e do extremo sul, acrescidas dos corpos policiais de S. Paulo, Pará e Amazonas. Nessa convergência para o seio da antiga metrópole, o paulista, forma delida do bandeirante aventuroso; o rio-grandense, cavaleiro e bravo; e o curiboca nortista, resistente como poucos - índoles díspares, homens de opostos climas, contrastando nos usos e tendências étnicas, do mestiço escuro ao caboclo trigueiro e ao branco, ali se agremiavam sob o liame de uma aspiração uniforme. A antiga capital agasalhava-os no recinto de seus velhos baluartes, rodeando num mesmo afago carinhoso e ardente a imensa prole havia três séculos erradia. Depois de longamente dispersos, os vários fatores da nossa raça volviam repentinamente ao ponto de onde tinham partido, tendendo para um entrelaçamento belíssimo. A Bahia ataviara-se para os receber . Transfigurou-a aquele fluxo da campanha - mártires que chegavam, combatentes que seguiam — e, partida a habitual apatia, revestiu a feição guerreira do passado. As inúteis fortalezas, que se lhe intercalam, decaídas à parceria burguesa das casas, no alinhamento das ruas, prontamente reparadas, cortadas as árvores que nasciam nas fendas das suas 
muralhas, ressurgiam à luz, recordando as quadras em que rugiam naquelas ameias as longas colubrinas de bronze.

Nelas aquartelavam os contingentes recém-vindos: o $1^{\circ}$ Batalhão Policial de S. Paulo, com 458 praças e 21 oficiais, comandado pelo tenentecoronel Joaquim Elesbão dos Reis; os $29^{\circ}, 39^{\circ}, 37^{\circ}, 28^{\circ}$, e $4^{\circ}$, dirigidos pelo coronel João César de Sampaio, tenentes-coronéis José da Cruz, Firmino Lopes Rego e Antônio Bernardo de Figueiredo e major Frederico Mara, com efetivos sucessivos de 240 praças e 27 oficiais, 250 praças e 40 oficiais, 332 praças e 51 oficiais, 250 praças e 11 oficiais, além de 36 alferes adidos, e o $4^{\circ}$ com 219 praças e 11 alferes que eram toda a oficialidade, não tendo nem capitães nem tenentes. Por fim dois corpos: o Regimento Policial do Pará, somando 640 combatentes, comandados pelo coronel José Sotero de Meneses, e um da polícia do Amazonas, sob o comando do tenente Cândido José Mariano, com 328 soldados.

Estes reforços, que montavam a 2.914 homens incluídos perto de trezentos oficiais, foram repartidos em duas brigadas, a de linha, ao mando do coronel Sampaio e os da polícia - excluída a de S. Paulo, que seguira isolada na frente, sob o do coronel Sotero - constituindo uma divisão que foi entregue ao general de Brigada Carlos Eugênio de Andrade Guimarães.

Todo o mês de agosto gastou-se em mobilizá-los. Chegavam destacadamente à Bahia; municiavam-se e embarcavam para Queimadas e dali para Monte Santo, onde deviam concentrar-se nos primeiros dias de setembro.

Os batalhões de linha, além de desfalcados, como o indicam os números acima, reduzidos quase a duas companhias, vinham desprovidos de tudo, sem os mais simples apetrechos bélicos — à parte as espingardas velhas e o fardamento ruço, que haviam servido na recente campanha federalista do Sul.

\section{O marechal Bittencourt}

O marechal Carlos Machado de Bittencourt, principal árbitro da situação, desenvolveu, então, atividade notável.

Vinha de molde para todas as dificuldades do momento.
Era um homem frio, eivado de um ceticismo tranquilo e inofensivo. $\mathrm{Na}$ sua simplicidade perfeitamente plebeia se amorteciam todas as expansões generosas. Militar às direitas, seria capaz - e demonstrou-o mais tarde ultimando tragicamente a vida — de se abalançar aos maiores riscos. Mas friamente, equilibradamente, encarrilhado nas linhas inextensíveis do dever. Não era um bravo e não era um pusilânime.

Ninguém podia compreendê-lo arrebatado num lance de heroísmo. Ninguém podia imaginá-lo subtraindo-se tortuosamente a uma conjuntura perigosa. Sem ser uma organização militar completa e inteiriça, afeiçoara-se todavia ao automatismo típico dessas máquinas de músculos e nervos feitas para agirem mecanicamente à pressão inflexível das leis.

Mas isto menos por educação disciplinar e sólida que por temperamento, inerte, movendo-se passivo, comodamente endentado na entrosagem complexa das portarias e dos regulamentos. Fora disto era um nulo. Tinha o fetichismo das determinações escritas. Não as interpretava, não as criticava: cumpria-as. Boas ou péssimas, absurdas, extravagantes, anacrônicas, estúpidas ou úteis, fecundas, generosas e dignas, tornavam-no, proteiforme, espelhando-as — bom ou detestável, extravagante ou generoso e digno. Estava escrito. Por isto, todas as vezes que os abalos políticos lhas baralhavam, se retraía cautelosamente ao olvido.

O marechal Floriano Peixoto - profundo conhecedor dos homens do seu tempo - nos períodos críticos de seu governo, em que a índole pessoal de adeptos ou adversários influía, deixou-o sempre, sistematicamente, de parte. Não o chamou; não o afastou; não o prendeu. Era-lhe por igual desvalioso como adversário ou partidário. Sabia que o homem, cuja carreira se desatava numa linha reta, seca, inexpressiva e intorcível, não daria um passo a favor ou contra no travamento dos estados de sítio.

\section{A República fora-lhe acidente inesperado no fim da vida.}

Não a amou nunca. Sabem-no quantos com ele lidaram. Foi-lhe sempre novidade irritante, não porque mudasse os destinos de um povo senão porque alterava umas tantas ordenanças e uns tantos decretos, e umas tantas fórmulas, velhos preceitos que sabia de cor e salteado.

Ao seguir para a Bahia desenfluíra todos os entusiasmos. Quem dele se abeirasse, buscando alentos de uma intuição feliz ou um traço varonil, 
sulcando a situação emocionante e grave, que até lá o arrastava, topava, surpreso, a esterilidade de uns conceitos triviais, longas frivolidades cruelmente enfadonhas sobre paradas de tropas, intermináveis minúcias sobre distribuição de gêneros e remontas de cavalhadas - como se este mundo todo fosse uma imensa Casa da Ordem, e a História uma variante da escrituração dos sargentos.

Saltou naquela capital quando ia em sua plenitude o fervor patriótico de todas as classes; e de algum modo o amorteceu. Manifestações ruidosas, versos flamívomos, oradores explosivos passaram-lhe por diante, estrondaram-lhe em torno, deflagraram-lhe aos ouvidos, num estrepitar de palmas e aplausos. Ouviu-os indiferente e contrafeito. Não sabia respondêlas. Tinha a frase emperrada e pobre. Além disso, tudo quanto saía do passo ordinário da vida não o comovia, desorientava-o, contrariava-o.

Recém-vindos da luta, requerendo uma transferência ou uma licença, nada adiantavam se, dispensando a formalidade de um atestado médico, lhe pusessem à vista apenas o rombo de um tiro de trabuco ou um gilvaz sanguíneo ou um rosto cadavérico de esmaleitado. Eram coisas banais, do ofício.

\section{Quadro lancinante}

Certa vez essa insensibilidade lastimável calou profundamente. Foi numa visita a um dos hospitais.

O quadro do amplo salão era impressionador...

Imaginem-se dois extensos renques de leitos alvadios, e sobre eles em todas as atitudes, rígidos debaixo dos lençóis escorridos como mortalhas; de bruços, ou acaroados com os travesseiros, em mudos paroxismos de dores; sentados, ou acurvados, ou estorcendo-se em gemidos — quatrocentos baleados! Cabeças envoltas em tiras sanguinolentas; braços partidos, em tipoias; pernas encanadas, em talas, rigidamente estendidas; pés disformes pela inchação, atravessados de espinhos; peitos broqueados à bala ou sarjados à faca; todos os traumatismos e todas as misérias...

A comitiva que encalçava o ministro - autoridades estaduais e militares, jornalistas, homens de toda a condição — ali entrou silenciosamente, tolhida de assombros.
Começou a lúgubre visita. O marechal aproximava-se de um ou outro leito, lendo maquinalmente a papeleta pendida à cabeceira; e seguia.

Mas teve que estacar um momento. Surgira-lhe em frente, emergindo dos cobertores, a face abatida de um velho, um cabo-de-esquadra, veterano de 35 anos de fileira. Uma vida batida a coice de armas desde os pântanos do Paraguai às caatingas de Canudos... E no rosto macilento do infeliz resplandecia um belo riso jovial e forte. Reconhecera o ministro do qual fora ordenança nos bons tempos de moço, em que o acompanhara na batalha, nos acantonamentos, nas longas marchas fatigantes. E dizia-o, agitado, voz sacudida e rouca, numa alegria dolorosíssima, num delírio de frases rudes e sinceras - olhos refulgentes de alacridade e de febre, e forçando por erguer-se, abordoando o tronco esmirrado aos braços finos e trêmulos; entreaberta a camisa de algodão deixando ver, na clavícula, a nódoa de uma cicatriz antiga...

Era empolgante a cena. Resfolegaram surdamente, opressos, todos os peitos. Empanaram-se todas as vistas, de lágrimas... e o marechal Bittencourt prosseguiu, tranquilamente, continuando a leitura maquinal das papeletas.

É que tudo aquilo — fortes emoções ou quadros lancinantes estava fora do programa. Não o distraía.

Era realmente o homem feito para aquela emergência. O governo não depararia quem melhor lhe transmitisse a ação, intacta, rompendo retilineamente no tumulto da crise.

Nesse abnegar-se a si próprio, abdicando todas as regalias da própria posição, fez-se, na lídima significação do termo, o Quartel-Mestre-General de uma campanha em que era chefe supremo um seu inferior hierárquico.

É que um bom senso sólido, blindado da frieza que o libertava de quaisquer perturbações, fizera que ele apanhasse, de um lance, as exigências reais da luta. Destas — compreendeu-o logo — a menos valiosa era, de certo, a acumulação de um maior número de combatentes no conflito. Estes, penetrando a região conflagrada, agravariam antes o estado dos companheiros, que pretendessem auxiliar, se lá fossem compartir as mesmas provações, reduzir-lhes os recursos escassos no concorrerem à mesma penúria. $\mathrm{O}$ que era preciso combater a todo o transe, e vencer, não 
era o jagunço, era o deserto. Fazia-se imprescindível dar à campanha o que ela ainda não tivera: uma linha e uma base de operações. Terminava-se por onde devia começar-se. E foi essa a empresa impulsionada com sucesso pelo ministro. Atraído durante toda a estadia na Bahia por sem número de questões de pormenores - equipamento dos batalhões que chegavam e acomodações para as turmas incessantes de feridos — o seu espírito superpunha-lhes sempre aquele objetivo capital, condição preponderante, e talvez única, do sério problema a resolver. Venceu-o, por fim, num destruir tenaz de numerosas dificuldades.

Nos últimos dias de agosto organizara-se, afinal, definitivamente, um corpo regular de comboios, atravessando continuamente os caminhos e ligando de modo efetivo, com breves intervalos de dias, o exército em operações a Monte Santo.

Este resultado pressagiava o desenlace próximo da contenda. Porque desde o começo, revelam-no as expedições antecedentes, as causas do insucesso em grande parte repousavam no insulamento em que cegamente se encravaram os expedicionários perdendo-se na região estéril, isolando-se diante do inimigo em espetaculosas diligências policiais, onde não havia rastrear-se os mínimos preceitos da estratégia.

O marechal Bittencourt fez, pelo menos, isto: transmudou um conflito enorme em campanha regular. A que até então se fizera traduzirase num prodigalizar inútil da bravura, mas o heroísmo e abnegação mais rara não a impulsionaram. Cristalizara num assédio platônico e dúbio, recortado de fuzilarias inúteis, em que se jogava nobre e estupidamente a vida. E este prolongar-se-ia, indeterminado, até que o arraial sinistro absorvesse, um a um, os que o acometiam. Em tal caso a simples substituição dos que ali tombavam - oito a dez por dia - por outros, tornava-se um círculo vicioso crudelíssimo. Além disto, numerosos assaltantes eram uma agravante. Circulariam todo o povoado, trancar-lheiam todas as saídas, mas teriam, passados poucos dias, latentes em roda, as linhas do outro cerco intangível e formidável — o deserto recretado, das caatingas, pondo-os nas aperturas crescentes e inelutáveis da fome.

Previu-o o marechal Bittencourt.

\section{Colaboradores prosaicos demais}

Um estrategista superior, atraído pela forma técnica e alta da questão, gizaria rasgos estupendos de tática e não a resolveria. Um lidador brilhante idearia novas arrancadas impetuosas, que esmagassem de vez a rebeldia, e extenuar-se-ia, inútil, a marche-marche pelas caatingas. O marechal Bittencourt, indiferente a tudo isto — impassível dentro da impaciência geral -, organizava comboios e comprava muares...

De feito, aquela campanha cruenta e na verdade dramática só tinha uma solução, e esta singularmente humorística.

Mil burros mansos valiam na emergência por 10 mil heróis. A luta com todo o seu cortejo de combates sangrentos descambava, deploravelmente prosaica, a um plano obscuro.

Dispensava o heroísmo, desdenhava o gênio militar, excluía o arremesso das brigadas, e queria tropeiros e azêmolas. Esta maneira de ver implicava com o lirismo patriótico e doía, feito um epigrama malévolo da História, mas era a única. Era forçada a intrusão pouco lisonjeira de tais colaboradores em nossos destinos. O mais caluniado dos animais ia assentar, dominadoramente, as patas entaloadas em cima de uma crise, e esmagá-la...

Ademais, somente eles podiam dar às operações a celeridade exigida pelas circunstâncias. É o caso que a guerra só podia delongar-se por mais dois meses, no máximo. Mais três meses seriam - e não havia remover a conclusão inabalável - a derrota, o abandono de quanto se havia feito, a paralisação obrigada.

Ia entrar, em novembro, sobre aquela zona, o regime torrencial e dele decorreriam consequências insanáveis.

Nos leitos, até então secos, dos regatos, acachoariam rios de águas barrentas, e o Vaza-Barris, intumescido de repente, transmudar-se-ia em onda enorme e dilatada, rolando transbordante, intransponível, cortando todas as comunicações.

Depois, quando as caudais se extinguissem, rápidas - porque o turbilhão das águas, derivando para o S. Francisco e para o mar, se esgota com a mesma celeridade com que se forma - despontariam entraves mais 
graves. Sob a adustão dos dias ardentíssimos, cada banhado, cada lagoa efêmera, cada caldeirão encovado nas pedras, cada poça de água — é um laboratório infernal, destilando a febre que irradia latente nos germes do impaludismo, profusamente disseminados nos ares, ascendendo em número infinito de cada ponto em que bata um raio de sol e descendo sobre as tropas, milhares de organismos em que as fadigas criavam receptividade mórbida funesta.

Era preciso liquidar a pendência antes dessa quadra perigosa, dispondo as coisas para um sítio real e firme determinando a rendição imediata. E, vencido o inimigo que podia ser vencido, recuar incontinente ante o inimigo invencível e eterno - a terra desolada e estéril. Mas para tal era indispensável garantir-se a subsistência do exército que, com os recentes reforços, montaria cerca de 8 mil homens.

\section{Conseguiu-o o ministro da Guerra.}

De sorte que ao partir, em começo de setembro, para Queimadas estavam dispostos todos os elementos para desenlace próximo: aguardavam-no, concentradas em Monte Santo, as brigadas da Divisão Auxiliar; seguiam, ainda que raros, os primeiros comboios regulares para Canudos.

\section{Em Canudos}

Iam ainda a tempo de reanimar a expedição que até àquela data atravessara, presa aos flancos do arraial, quarenta e tantos dias de agitação perigosa e inútil. Definimo-la já, em breve diário, que não alongamos para evitar a mesmice dolorosa de episódios sucedendo-se sem variantes apreciáveis.

Os mesmos tiroteios improvisos, violentos, instantâneos, em horas incertas; os mesmos armistícios enganadores; a mesma apatia recortada de alarmas; a mesma calma estranha e esmagadora, intermitentemente rota de descargas...

Combates diários, ora mortíferos rareando as fileiras e desfalcando-as de oficiais prestimosos, ora ruidosos e longos, mas à maneira dos recontros entre os mercenários na Idade Média, esgotando-se num dispêndio de milhares de balas, sem um ferido, sem um escoriado sequer, de lado a lado.
Por fim a existência aleatória, a terços de rações, quando as havia, dividindo-se um boi por batalhão e um litro de farinha por esquadra; e, como nos maus dias da Favela, as empresas diárias, em que se escalavam corpos para arrebanharem gado.

Os comboios eram raros e incertos. Chegavam escassos, extraviandose parte das cargas pelos caminhos. Diante dos expedicionários se levantou de novo, como perigo único, a fome.

Metidos nos casebres, ou nas tendas por detrás dos morros, ou colados às escarpas das trincheiras, pouco se temiam do jagunço. Os perigos consistiam, exclusivos, nas caçadas, que estes faziam, de incautos que se afastavam dos abrigos. As duas torres da igreja nova lá estavam sobranceiras na altura, como dois mutãs sinistros sobre o exército. E nada escapava à pontaria dos que as guarneciam e que não as abandonavam no maior fragor dos canhoneios. A travessia para a Favela continuava, por isto, perigosa, tornando-se necessário estacionar uma guarda à margem do rio, no ponto em que ia dar o caminho, a fim de impedir que para lá seguissem soldados imprudentes. Naquele ponto recebiam o batismo de fogo os reforços que chegavam: a Brigada Girard a 15 de agosto, reduzida a 892 praças e 56 oficiais; o Batalhão Paulista a 23, com 424 praças e 21 oficiais; o $37^{\circ}$ de Infantaria, que precedera a Divisão Auxiliar, com 205 praças e 16 oficiais, comandado pelo tenente-coronel Firmino Lopes Rego. Os rudes adversários deixavam-nos descer em paz as últimas abas da montanha, timbrando em lhes fazer no último passo, embaixo, no álveo do rio, uma recepção retumbante e teatral, de tiros, cortada invariavelmente de estrídulos assovios terrivelmente irônicos.

É que não os assustavam os novos antagonistas. Permaneciam na mesma atitude desafiadora, inamolgáveis. E pareciam disciplinar-se. Correspondiam-se, de um a outro extremo do povoado, ao través do casario, a disparos combinados de bacamartes. Arrojavam-se mais ordenados e seguros nos assaltos. Recebiam, por sua vez, comboios, entrando pelos caminhos da Várzea da Ema, sem que lhos capturasse a tropa assaltante para não desguarnecer as posições ocupadas ou, consideração mais séria, evitar ciladas perigosas. Porque pelas cercanias, derivando invisíveis pelas colinas do norte e dali para Canabrava e Cocorobó, circulando de longe os batalhões, rondavam rápidas colunas volantes de jagunços, das quais havia sinais iniludíveis. Não raro o soldado inexperto, ao avultar sobre um cerro, 
baqueava atravessado por uma bala, que partia de fora do arraial, das linhas intangíveis daquele outro assédio abarcando a tropa. Os animais de montaria e tração eram muitas vezes espavoridos a tiro, nas pastagens que se alongavam pelas duas margens do rio; e em certo dia de agosto 20 muares da artilharia foram capturados, apesar de estarem sob a guarda de um batalhão aguerrido, o $5^{\circ}$ de Linha, sobre o qual se fez carga da importância da presa.

Estes incidentes delatavam raro alento entre os rebeldes.

Não lhes davam, entretanto, tréguas os assaltantes. Os três Krupps que desde 19 de julho emparcavam sobre a encosta, tendo no sopé a vanguarda do $25^{\circ}$ sobranceando a praça, batiam-nos noite e dia ateando incêndios a custo debelados e arruinando inteiramente a igreja velha, de madeiramento já todo exposto a ressaltar no telhado abatido em parte e em cujo campanário não se compreendia que ainda subisse à tarde o impávido sineiro, tangendo as notas consagradas da Ave-Maria.

\section{O sino da igreja}

Como se não bastasse aquele bombardeio à queima-roupa, descera, a 23 de agosto, do alto da Favela, o Whitworth. Naquele dia fora ferido o general Barbosa, quando inspecionava a bateria do centro, próxima ao quartel-general da $1^{\text {a }}$ coluna. De sorte que a vinda do monstruoso canhão dava oportunidade a revide imediato. Este realizou-se logo ao amanhecer do dia subsequente. E foi, de fato, formidando. A grande peça detonou: viu-se arrebentar, com estrondo, o enorme shrapnel entre as paredes da igreja, esfarelando-lhe o teto, derrubando os restos do campanário e fazendo saltar pelos ares, revoluteando, estridulamento badalando, como se ainda vibrasse um alarma, o velho sino que chamava ao descer das tardes os combatentes para as rezas...

\section{Fuzilaria}

Mas, tirante este incidente, fora perdida a jornada: quebrara-se uma peça do aparelho obturador do canhão fazendo-o emudecer para sempre. Caíram nas linhas de fogo oito soldados, e uma fuzilaria fechada, estupenda, incomparável, entrou pela noite dentro até ao amanhecer.
Reatou-se durante o dia, após ligeiro armísticio, vitimando mais quatro soldados, que com seis do $26^{\circ}$, que aproveitando o tumulto desertaram, elevaram a dez as perdas do dia. Continuou no dia 26, abatendo cinco praças; matando quatro, no dia 27; quatro, no dia 28; no dia 29, quatro soldados e um oficial; e assim por diante na mesma escala inflexível, que exauria a tropa.

As baixas, somando-se diariamente em parcelas pouco díspares, com os claros abertos em todas as fileiras pelos combates anteriores, tinham já, desde meados de agosto, imposto a reorganização das forças rarescentes. $\mathrm{Na}$ diminuição que tivera o número de brigadas, passando de sete a cinco, e no descair das graduações dos comandos, percebia-se, apesar dos reforços recém-vindos, o enfraquecimento da expedição ${ }^{1}$.

1 “Quartel-General do Comando-em-chefe - Campo de combate em Canudos, 17 de agosto de 1897 - Ordem do dia $n^{\circ} 102$ - Reorganização das forças em operações no interior do Estado.

Nesta data passa a ter a seguinte organização a força do meu comando: $14^{\circ}$ batalhão de infantaria sobre o comando do capitão do $32^{\circ}$ Antônio da Silva Paraguaçu; $22^{\circ}$ sob o comando do major do mesmo corpo Lídio Corpo; $24^{\circ}$ sob o comando do major do mesmo corpo Henrique José de Magalhães; $38^{\circ}$ sob o comando do capitão do mesmo corpo Afonso Pinto de Oliveira, todos da arma de infantaria, constituindo a $1^{a}$ brigada, sob o comando do coronel do $14^{\circ}$ Joaquim Manoel de Medeiros; $15^{\circ}$ sob o comando do capitão do $38^{\circ}$ José Xavier de Figueiredo Brito; $16^{\circ}$ sob o comando do capitão do $24^{\circ}$ Napoleão Felipe Aché; $27^{\circ}$ sob o comando do capitão do $24^{\circ}$ Tito Pedro Escobar; $33^{\circ}$ sob o comando do capitão José Soares de Melo, constituindo a $2^{\mathrm{a}}$ brigada, sob o comando do coronel do $27^{\circ}$ Inácio Henrique de Gouveia; $5^{\circ}$ comando pelo capitão Leopoldo Barros e Vasconcelos, do mesmo corpo; $7^{\circ}$ sob o comando do capitão do mesmo corpo Alberto Gavião Pereira Pinto; 25 sob o comando do major Henrique Severiano da Silva; $34^{\circ}$ comandado pelo capitão Pedro de Barros Falcão, constituindo a $3^{\text {a }}$ brigada, sob o comando do tenente-coronel do $25^{\circ}$ Emídio Dantas Barreto; $5^{\circ}$ regimento de artilharia , comandado pelo capitão do mesmo João Carlos Pereira Ibiapina; bateria do $2^{\circ}$ regimento sob o comando do $1^{\circ}$ tenente do $5^{\circ}$ batalhão de posição Afrodísio Borba e bateria de tira rápido comandada pelo capitão do $1^{\circ}$ de posição Antônio Afonso de Carvalho, constituindo a brigada de artilharia, sob o comando do coronel do $5^{\circ}$ regimento Antônio Olímpio da Silveira, cujas brigadas ficam fazendo parte da $1^{\mathrm{a}}$ coluna, sob o comando do general de brigada João da Silva Barbosa; $9^{\circ}$ batalhão de infantaria, sob o comando do capitão do $31^{\circ}$ José Lauriano da Costa; $26^{\circ}$ do comando do capitão do $40^{\circ}$ Francisco de Moura Costa; $32^{\circ}$ sob o comando do major do mesmo corpo Florismundo Colatino dos Reis Araújo Góis; $35^{\circ}$ comandado pelo campitão Fortunato de Sena Dias, constituindo a $4^{\mathrm{a}}$ brigada, do comando do coronel do $32^{\circ}$ Donaciano de Araújo Pantoja; $12^{\circ}$ de infantaria do comando do capitão do $31^{\circ}$ Joaquim Gomes da Silva; $30^{\circ}$ comandado pelo capitão Altino Dias Ribeiro; $31^{\circ}$ sob o comando do major do mesmo corpo João Pacheco de Assis; $40^{\circ}$ sob o comando do major Manual Nonato Neves de Seixas, 
Dos vinte batalhões de infantaria que lá estavam - à parte $05^{\circ}$ Regimento de Artilharia, o $5^{\circ}$ da Polícia Baiana, uma bateria de tiro rápido e um esquadrão de cavalaria — , quinze eram comandados por capitães e duas brigadas por tenentes-coronéis, não descendo o das companhias aos sargentos por ser maior que o destes o número de alferes.

Breve, porém, a situação mudaria. Canudos teria em torno, em algarismos rigorosamente exatos, trinta batalhões, excluídos os corpos de outras armas ${ }^{2}$.

Avançava pelos caminhos a divisão salvadora.

constituindo a $5^{\mathrm{a}}$ brigada do comando do tenente-coronel do $30^{\circ}$ Antônio Tupi Ferreira Caldas, as quais formarão a $2^{\mathrm{a}}$ coluna sob o comando interino do coronel Joaquim Manuel de Medeiros, passando a comandar interinamente a $1^{\mathrm{a}}$ brigada o major do $16^{\circ}$ Aristides Rodriguez Vaz."

$24^{\circ}, 5^{\circ}, 7^{\circ}, 9^{\circ}, 12^{\circ}, 14^{\circ}, 15^{\circ}, 16^{\circ}, 22^{\circ}, 23^{\circ}, 24^{\circ}, 25^{\circ}, 26^{\circ}, 27^{\circ}, 28^{\circ}, 29^{\circ}, 30^{\circ}, 31^{\circ}, 32^{\circ}, 33^{\circ}, 34^{\circ}$, $35^{\circ}, 37^{\circ}, 38^{\circ}, 40^{\circ}$ de linha; $5^{\circ}$ da Bahia; 1 de São Paulo, 2 do Pará; 1 do Amazonas. Ao todo 30.

Adite-se: $5^{\circ}$ regimento de artilharia; bateria do $2^{\circ}$ regimento da mesma arma; uma bateria de tiro rápido; um esquadrão de cavalaria; o $4^{\circ}$ corpo de polícia baiana e o batalhão patriótico “Moreira César”, dos comboios. 